inis i

\begin{tabular}{|l|l|}
\hline 2. To: (Receiving Organization) & $\begin{array}{l}\text { 3. From: Coriginating } \\
\text { Organization) } \\
\text { COGEMA Engineering Corp. }\end{array}$ \\
Distribution & $\begin{array}{l}\text { 6. Design Authority/ Design } \\
\text { Agent/Cog. Engr.: } \\
\text { 5. Proj./Prog. /Dept./Div.: }\end{array}$ \\
\hline HTI &
\end{tabular}

8. Originator Remarks:

For approval and release.

9. Equip./Component No.

10. System/Bldg./Facility: 200Gen

11. Receiver Remarks: 11A. Design Baseline Document? [] Yes [X] No

12. Major Assm. Dwg. No.:

N/A

13. Permit/Permit Application No.:

N/A

14. Required Response Date

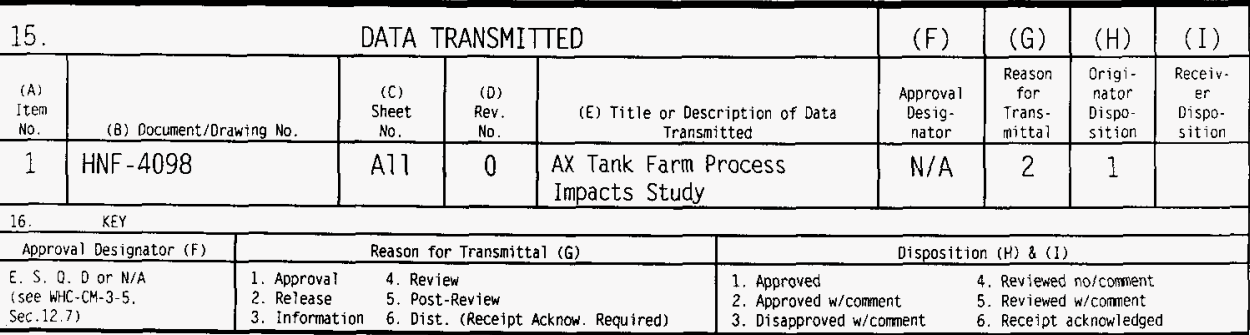

17. SIGNATURE/DISTRIBUTION

(See Approval Designator for required signatures)

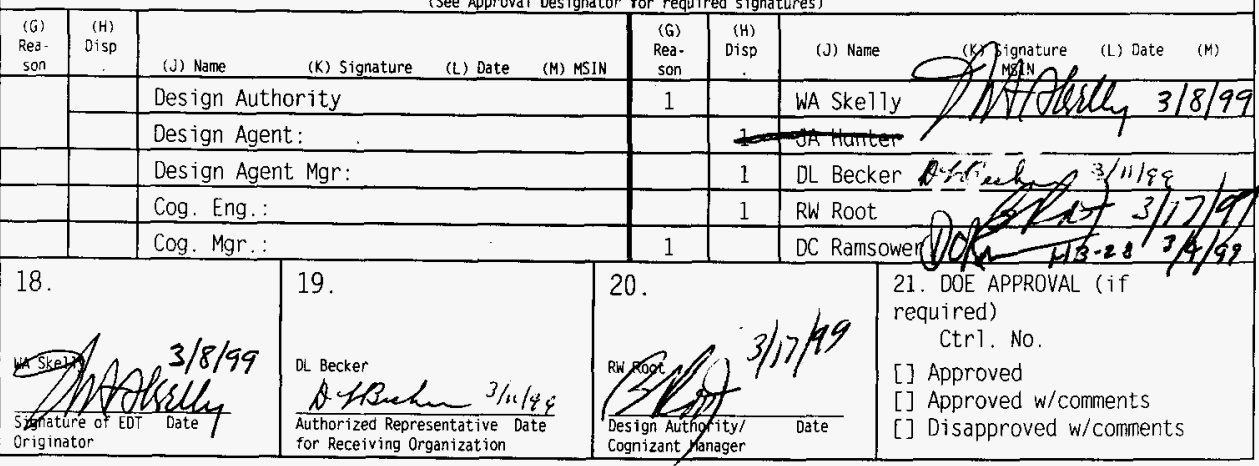

BD-7400-172-2 (05/96) GEF097 


\title{
AX Tank Farm Process Impacts Study
}

\author{
W. A. Skelly \\ M. D. Crippen \\ COGEMA Engineering Corp, \\ Richland, WA 99352 \\ U.S. Department of Energy Contract DE-AC06-96RL13200
}

EDT/ECN: 619524

UC: 510

Org Code: 73500

CACN: 103226

COA: AA20

B\&R Code: EW02J1190

Total Pages: 139

Key Words: AX Tank Farm, Hanford Tanks Initiative, New Processing Facility, heavily contaminated debris, waste process flow sheet, waste treatment, tank and ancillary equipment debris treatment.

Abstract: This study provides facility and process concepts and costs for partial decontamination of the most heavily contaminated debris from the demolition of the four AX tanks and ancillary equipment items. This debris would likely be classified as high-level and/or remote handle TRU waste based on source and radiological inventory. A process flow sheet was developed to treat contaminated metal wastes such as pipes and tank liners as well as contaminated concrete and the residual waste and grout left in the tanks after final waste retrieval. The treated solid waste is prepared for delivery to either the ERDF or the Low-Level waste burial grounds. Liquid waste products are delivered to the private vitrification contractor for further treatment and storage. This is one of several reports prepared for use by the Hanford Tanks Initiative Project to develop retrieval performance criteria for tank farms.

TRADEMARK DISCLAIMER. Reference herein to any specific commercial product, process, or service by trade name. trademark, manufacturer. or otherwise. does not necessarily constitute or imply its endorsement, recommendation. or favoring by the United States Government or any agency thereof or its contractors or subcontractors.

Printed in the United States of America. To obtain copief of thic documant contact Document Control Services. P.0. Box 950. Mailstop H6-08. Richland WA 99352. Phone (509) 372-2420: $\operatorname{Fax}(509) 376-4989$.
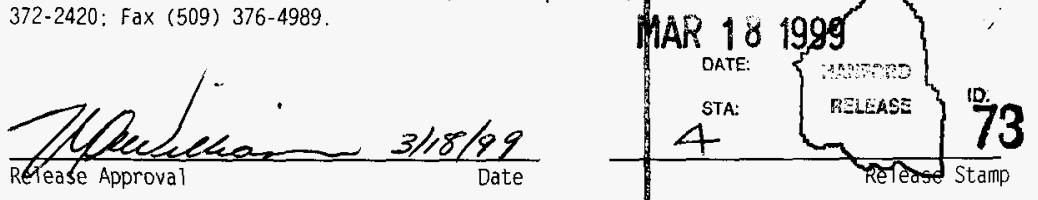

\section{Approved for Public Release}




\section{CONTENTS}

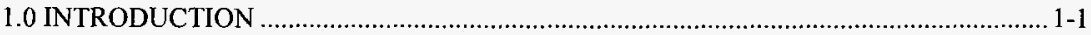

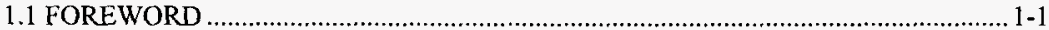

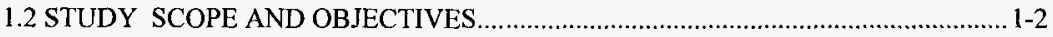

2.0 WASTE INVENTORY DESCRIPTIONS .............................................................. 2-1

2.1 HEAVILY CONTAMINATED SOIL, METAL, AND CONCRETE DEBRIS FROM

TANK REMOVAL ........................................................................................ 2-1

2.2 HEAVILY CONTAMINATED METAL AND CONCRETE DEBRIS FROM

REMOVAL OF ANCILLARY EQUIPMENT ……………............................................2-2

3.0 PROCESS DESCRIPTION ……................................................................................ $3-1$

3.1 INTRODUCTION AND APPROACH ………................................................

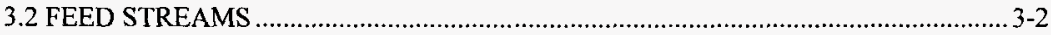

3.3 METAL WASTE PROCESSING................................................................... 3-4

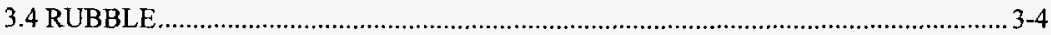

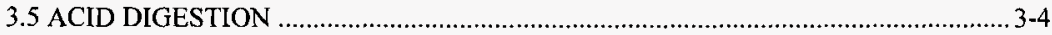

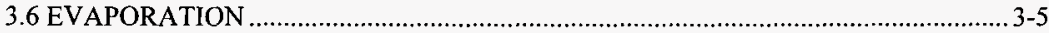

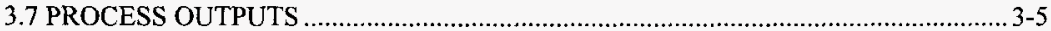

4.0 DESCRIPTION OF PROCESS FACILITY AND EQUIPMENT …................................ 4-1

4.1 FACILITY DESCRIPTION ................................................................................... 4-1

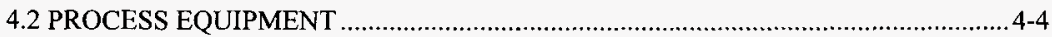

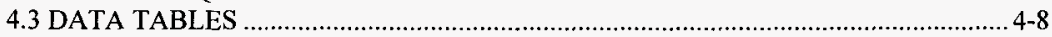

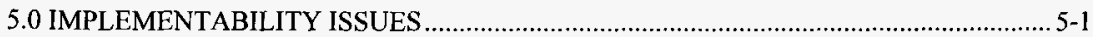

5.1 DESIGN MATURITY ....................................................................................

5.2 UTILITY OF NTF PROCESS CONCEPT FOR TREATING LARGE VOLUMES OF CONTAMINATED SOIL ....................................................................................... 5-1

5.3 LARGE PROJECTED VOLUME OF CATEGORY 3 WASTE …............................... 5-1

5.4 STORAGE SPACE IN DSTS.

5.5 ADDITIONAL LIFE-CYCLE COST CONSIDERATIONS …………………............ 5-2

5.6 SHIELDED CONTAINERS ..............................................................................

5.7 APPLICATIONS FOR ROBOTICS AND/OR REMOTE-OPERATED EQUIPMENT 5-3

5.8 CLOSED-LOOP OPERATION ............................................................................ 5-3

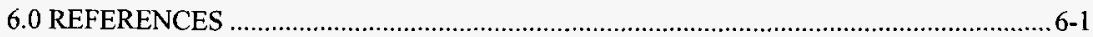

APPENDIX A. Pre-Processing Facility Material Balance ..................................................... A-1

APPENDIX B. Capital Cost Estimate for Proposed New Treatment Facility ...........................B-1

APPENDIX C. Operating Cost Estimate for Processing Debris from AX Tank Farm

Through Proposed New Treatment Facility. 


\section{LIST OF TABLES}

Table 2-1. Best Estimates of Nonradiological Inventories in Base Slab Debris from Tank Removal (in $\mathrm{kg}$ ) $2-5$

Table 2-2. Best Estimates of Radiological Inventories in Base Slab Debris from Tank Removal (in curies) 2-6

Table 2-3. Best Estimates of Nonradiological Inventories in Heavily Contaminated Debris from Ancillary Equipment Removal (in kg). $2-8$

Table 2-4. Best Estimates of Radiological Inventories in Heavily Contaminated Debris from Ancillary Equipment Removal (in curies).

Table 4-1. Waste Form and Volume Projections

Table 4-2. Construction Resource Requirements 4-10

Table 4-3. Radiological Air Emissions (in curies). 4-11

Table 4-4. Manning List for the Proposed New Treatment Facility 4-13

Table 4-5. Cost Summary 4-15

\section{LIST OF FIGURES}

Figure 3-1. New Treatment Facility Flowsheet 3-3

Figure 4-1. New Treatment Facility.

Figure 4-2. Process Impacts Study Schedule 


\subsection{INTRODUCTION}

\subsection{FOREWORD}

In May of 1996, the U.S. Department of Energy (DOE) implemented a five-year demonstration project known as the Hanford Tanks Initiative (HTI). The scope of HTI is to:

- Demonstrate alternate retrieval technologies for tank waste.

- Retrieve hard-heel waste from Tank 241-C-106 and assess compliance with retrieval performance evaluation criteria for that activity.

- Characterize residual waste in Tank 241-AX-104 and assess compliance with retrieval performance criteria for that tank.

- Develop retrieval performance evaluation criteria supporting readiness to close single-shell tanks (SSTs) in the future.

The HTI mission is to minimize technical uncertainties and programmatic risks by conducting demonstrations to characterize and remove tank waste using technologies and methods that will be needed in the future to carry out tank waste remediation and tank farm closure. A detailed description of the entire HTI Project is provided in the Hanford Tanks Initiative Plan, HNF-SDHTI-PLN-022.

The HTI project team is comprised of representatives from the Project Hanford Management Contract (PHMC), Pacific Northwest National Laboratory (PNNL), and private consultants. The team is working closely with the Washington State Department of Ecology (Ecology), various northwest stakeholders, and Native-American tribes to identify and develop waste retrieval performance criteria for subsequent formulation of acceptable closure criteria and standards for tank farms.

In August of 1996, the DOE and Ecology signed a memorandum of understanding (MOU) in which they agreed to collaborate in addressing the issues of "what degree of waste removal should be used as the basis for waste retrieval systems technology development, retrieval systems engineering, and definition of completion of retrieval operations." In preparing the agreement, the two agencies conceded that "it has not been established that 99 percent waste retrieval as defined in the Hanford Federal Facility Agreement and Consent Order (Tri-Party Agreement [TPA]) Milestone M-45-00 will be sufficient to allow closure of tank farms; nor has it been determined that 99 percent retrieval is technically achievable, or represents a performance objective that considers cost, technical practicality, exposure to radiation, and/or Nuclear Regulatory Commission requirements." Conditions of TPA Milestone M-45-00 stipulate that "in evaluating closure options for SSTs, contaminated soil, and ancillary equipment, Ecology and the Environmental Protection Agency (EPA) will consider cost, technical practicality, and potential exposure to radiation" (JEG 1997).

One essential element of the HTI mission is to provide a basis for future National Environmental Policy Act (NEPA) of 1969 safety and regulatory actions affecting waste retrieval and operable unit closure of the Hanford Site tank farms. This goal is being met by development of retrieval 
performance criteria, through assessment of the risk to human health and the environment. Several engineering studies have been conducted by COGEMA Engineering Corporation (COGEMA Engineering) and other contractors to provide essential data for these evaluations. In previous studies, COGEMA Engineering developed concepts for exposing, demolishing, and removing debris from the four AX tanks (AX Tank Farm Tank Removal Study); two alternate methodologies (an ex-situ method and an in-situ method) for remediation of residual vadose zone contamination following removal of the four tanks (AX Tank Farm Soil Remediation Study); and two alternate methodologies (an ex-situ method and an in-situ method) for remediation of related ancillary equipment (AX Tank Farm Ancillary Equipment Study). These reports describe concepts for performing the work, including descriptions of the layouts, equipment, labor, and materials that would be involved, together with characterizations of the concepts with respect to cost, technical practicality, and worker radiological exposures.

\subsection{STUDY SCOPE AND OBJECTIVES}

Beginning in 1997, HTI has undertaken a number of engineering studies to develop essential information and assessments regarding technologies, health and environmental risks, and costs associated with alternative strategies for closing single- shell tanks (SSTs) at the Hanford Site. Data from these studies are being applied, in turn, to the development of retrieval performance evaluation criteria for Hanford SSTs. The 241-AX Tank Farm has been designated as the "strawman" for these studies and assessments. Although it is the smallest of the 12 SST farms at the Hanford Site, it poses some of the greatest challenges for waste characterization, waste retrieval, and closure due to the tank dimensions, the concentration of in-tank hardware, the residual waste compositions, and the concentration and complex relationships between the tanks and associated ancillary equipment.

This study extends previous work by providing facility and process concepts for partial decontamination of the most heavily contaminated debris from demolition of the four AX tanks and related ancillary equipment items (i.e., debris that would likely be classified as high-level and/or remote-handle TRU waste based on source and radiological inventory). The statement of work for this study directed COGEMA Engineering to:

1. Use the information developed in previous HTI engineering studies regarding waste forms, volumes, generation rates, and contaminant inventories of the highly radioactive wastes generated during demolition of tanks and ancillary equipment to define the waste feed to be processed.

2. Develop a waste processing concept that is compatible with the current Tank Waste Remediation System (TWRS) decision logic.

3. Utilize processing concepts from earlier TWRS systems engineering studies to the maximum practical extent.

4. Develop a concept process flow diagram for treating these highly radioactive wastes.

5. Address packaging, transportation, and storage issues and cost consequences for all waste streams leaving the facility. 
Information developed in previous HTI engineering studies of the forms and compositions, volumes, generation rates, and contaminant inventories of the highly radioactive debris generated during demolition of tanks and ancillary equipment is summarized in Section 2 of this report.

The current TWRS decision logic for retrieval, treatment, and disposal of SST and double-shell tank (DST) waste can be generalized as follows:

1. Existing waste in DSTs will be mechanically agitated by mixer pumps to suspend the contained sludges to the maximum practical extent.

2. DST contents will be pumped to the Privatization Contractor's (PC's) designated staging tank.

3. In the PC's staging tank, the waste will go through multiple cycles of washing and mixing (i.e., mechanical agitation). After each wash cycle, the solids will be permitted to settle and the supernate will be decanted off to a low-activity waste (LAW) holding tank.

4. Radionuclides and hazardous constituents in the LAW waste stream will be permanently immobilized in a vitrified waste form. Immobilized LAW will be retained on site in a long-term storage facility.

5. Radionuclides and hazardous constituents in the washed solids (i.e., the high- level portion of the DST waste) will be permanently immobilized in glass logs in the PC's vitrification facility. Glass logs will be transported to the planned high- level waste disposal facility at Yucca Mountain, Nevada.

6. As storage space in DSTs becomes available, waste that is currently stored in SSTs will be retrieved and transferred to DSTs for safe interim storage. In due course, SST waste would go through the same treatment and disposal process described above for DST waste.

Schemes for treating heavily contaminated debris from demolition of SSTs and related ancillary equipment were evaluated by the TWRS Program in engineering studies predating the current TWRS decision logic, project baseline, and environmental impact statement. Appendix $J$ of a draft report entitled Systems Engineering Study for the Closure of Single-Shell Tanks (Boomer et al 1991) provides a conceptual description of a solid waste treatment facility (SWTF) that was envisioned to process $495,000 \mathrm{yd}^{3}\left(376,000 \mathrm{~m}^{3}\right)$ of material over a 10 -year period. The 1991 study does not anticipate the decision to vitrify tank waste for disposal, nor does it anticipate that a large-scale, special-purpose landfill would be constructed at Hanford to receive large volumes of lightly contaminated soil and demolition waste (i.e., the Environmental Restoration Disposal Facility [ERDF]). The 1991 study was terminated before all portions had been completed. However, the 60-percent report draft is available in the Hanford Site records system (Document Control) as a publicly released document. The draft report includes process flow diagrams, material balances, facility layouts, equipment lists, schedule information and costs. The draft report was extensively reviewed for applicability to the current work scope. Portions of the 
facility description and process logic from that study have been revised and incorporated into the current facility concept.

This report describes an updated waste processing facility concept supported by a revised process flow diagram and material balance. Initial best estimates (i.e., assumptions) for a number of essential performance parameters (e.g, decontamination factors, mechanical efficiencies) have been used in calculations to develop the supporting rationale for the concept. Notations are provided at appropriate points in figures, tables, and text of this report to identify these assumptions and the context(s) in which they are used. Typically, a chemical processing concept (or at least certain aspects of the process that are regarded as critical to concept viability) would be evaluated in a pilot plant setting. Such testing would provide data that could be used to verify key performance parameters, as well as indications of how the process logic and initial material balance estimates might be revised (optimized) to meet key objectives. Insofar as the process logic and material balance calculations in this report are untested and unproven, it should be understood that this report describes a process concept at the "initial best estimate" stage of maturity.

This study does not consider the issue of treating significant volumes of contaminated soil that might be created as the result of losses of sluicing liquors into the vadose zone during retrieval of waste from the AX tanks. Hypothetical leakage cases have been evaluated in other engineering studies commissioned by HTI. The conclusion has been advanced that contaminated soil excavated from "leakage plumes" could be handled and disposed as Category 1 and Category 3 low-level waste (LLW), for which there are existing disposal options on the Hanford Site. Processing of soil from leakage plumes through the facility described in this study would provide some reduction (possibly a significant reduction) in the volume of Category 3 soil for disposal. There would be a cost incentive (possibly a significant incentive) to use this facility to maximize the volume of soil disposed as Category $1 \mathrm{LLW}$ and to minimize the volume disposed as Category $3 \mathrm{LLW}$. Because this is an optimization problem as opposed to a technology or feasibility issue, it was determined to be extraneous to this study.

The principal purpose of this study and the new treatment facility (NTF) described in this report is to provide the capability to partially decontaminate highly radioactive debris resulting from demolition of SSTs and tank farm ancillary equipment. The intent of processing debris in this facility would be (1) to reduce the contaminant inventories in the incoming debris to the extent that all washed solids leaving the facility would contain acceptably low levels of residual contamination enabling them to be disposed on site either as Category 1 or Category $3 \mathrm{LLW}$ and (2) to recapture and concentrate the hazardous chemicals and radionuclides separated from the solids in a liquid waste stream that would be forwarded to DSTs for eventual vitrification. In the conceptualization process, consideration was given to the need for the waste going to DSTs to be compatible with current operational requirements (defined in the Tank Farms Authorization Basis) covering transfers to and interim safe storage in DSTs and to avoid concentrating constituents in this waste stream (e.g., iron, aluminum, zirconium) that are understood to be problematic for vitrification.

An objective of the study was to develop a wash concept that is sufficiently aggressive to ensure that contamination levels in all washed solids would be reducible below TRU and Category 3 LLW designation limits. No specific goals were set out for this study with regard to process optimization. However, in developing the process logic, consideration was given to 
incorporating the necessary flexibility into the process to ensure that it would be amenable to optimization at a later date. If the concept for the proposed NTF is pursued beyond the feasibility study stage into formal design, it is likely that additional objectives would be applied to process design/development to optimize the process in specific directions, e.g., to maximize production of Category $1 \mathrm{LLW}$, minimize Category $3 \mathrm{LLW}$, and minimize the volume of liquid waste going to DSTs. With the expenditure of some additional effort, significant refinement of the process flowsheet and material balance could be achieved before initiation of formal design. However, at an early stage of design, it would be essential to evaluate specific aspects of the process in a pilot plant. 
HNF-4098, Rev. 0

\subsection{WASTE INVENTORY DESCRIPTIONS}

In this study, facility requirements and process flow logic are to be evaluated for waste feed streams from the following sources:

a) Heavily contaminated soil, metal, and concrete debris from tank removal (demolition)

b) Heavily contaminated metal and concrete debris from removal (demolition) of ancillary equipment.

Removal of tanks and ancillary equipment from the AX Tank Farm have been examined in two previous engineering studies. Waste descriptions, volumes, and inventory data from the previous studies are summarized below. This information will be applied in the current study to conceptualize the essential process flow logic and equipment layout for the proposed NTF.

\subsection{HEAVILY CONTAMINATED SOIL, METAL, AND CONCRETE DEBRIS FROM TANK REMOVAL}

This material will be derived from demolition, removal, and loadout of debris from the lowermost portions (i.e., base slabs and footing ring sections) of the four AX tanks. A concept for tank demolition was proposed in AX Tank Farm Tank Removal Study, HNF-3378. That report provides estimates of quantities of heavily contaminated debris that would be produced from tank removal. Bounding estimates of the associated inventories of chemicals and radionuclides in the debris are provided in HNF-SD-HTI- TI-001 Rev. 0A (AX Tank Farm Waste Inventory Study). Relevant information from the two reports is summarized below:

Base slab debris will consist of a mixture of tank liner scrap, shielding grout, concrete rubble (from tank dome, sidewalls, footing ring and base slab), and some amount of soil from below the slab that will be picked up with the debris. The following itemization of debris (including bulking) originating from each of the four AX tanks was developed for estimating purposes in HNF-3378:

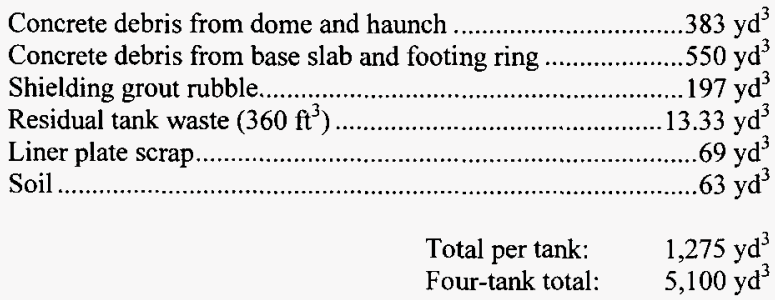

The tanks are lined to a height of $32 \mathrm{ft}$. with $3 / 8$-in. carbon steel plate. The combined liner surface area inside each tank is approximately $11,958 \mathrm{ft}^{2}\left(47,832 \mathrm{ft}^{2}\right.$ total). 
Containers will be specially fabricated steel cargo boxes measuring approximately $12.1 \mathrm{ft}$. long by $4.2 \mathrm{ft}$. wide by $3.3 \mathrm{ft}$. high, with 4 -in. thick steel tops and sides. Containers have been sized so that they can be transported by roll-on/roll-off ( $\mathrm{RO} / \mathrm{RO}$ ) trucks similar to those hauling to/from ERDF. These trucks have 38,000-lb. payloads. Base slab rubble is expected to exhibit specific activity levels of ${ }^{137} \mathrm{Cs}$ in the range of 0.2 to $0.5 \mathrm{Ci} / \mathrm{ft}^{3}$. The 4 -in. steel thickness is calculated to limit doses to $10 \mathrm{mR} / \mathrm{hr}$ at $1 \mathrm{~m}$. This criteria must be met in order to transport containers within the Hanford Site boundaries without barricading the route to other traffic. Due to the amount of steel required for shielding, the tare weight of the containers is estimated to be about 26,000 lbs. Cargo (base slab debris) will be limited to about $3.5 \mathrm{yd}^{3}$ per container (assuming a fill factor of about 80 percent and a bulk density of $120 \mathrm{lb} / \mathrm{ft}^{3}$ for debris). The 5,100 $\mathrm{yd}^{3}$ of base slab rubble would be delivered to the the NTF in 1,460 shielded containers (see Table 3.2 in HNF- 3378).

For purposes of evaluating exposures, waste segregation, and waste disposition issues in HNF3378 , it was assumed that the entire 1 percent residual inventories in the four AX tanks would be concentrated in a 1 -in. thick layer on the floor of each tank and would be firmly adhered to the liner. During base slab demolition, as the liner is wrenched and sheared apart into pieces that are small enough to be loaded into shielded boxes, some amount of tank waste would undoubtedly flake and spall off the liner plate and become comingled with other debris. Therefore, the initial tendency for tank waste to be segregated together with the liner plate scrap fraction of base slab debris may be lost as the debris is broken up and loaded out. Irrespective of how tank waste might become dispersed throughout base slab debris during the demolition and loadout operations, the total inventory is assumed to be essentially the same as the sums of the estimated residual nonradiological and radiological inventories for the four tanks reported in HNF-SDHTI-TI-001 Rev. 0A. The inventory information is found in the following tables: for Tank AX101, see Tables B-15 and B-16; for Tank AX-102, see Tables C-7 and C-8; for Tank AX-103, see Tables D-9 and D-10; and for Tank AX-104, see Tables E-6 and E-7. In all of the source tables, The 1 percent residual inventory estimates are listed under the heading of "Case II." The inventory data from the source tables is reproduced in Tables 2.1 and 2.2.

\subsection{HEAVILY CONTAMINATED METAL AND CONCRETE DEBRIS FROM REMOVAL OF ANCILLARY EQUIPMENT}

Concept methods for demolition and removal of these items are described in AX Tank Farm Ancillary Equipment Study, HNF-3441. Most of the proposed methods for demolition of ancillary equipment are extensions and/or modifications of methods proposed previously for demolishing tanks. In the ancillary equipment study, equipment items were grouped together as follows:

- surplus buildings and facilities

- vadose and groundwater monitoring wells

- riser penetrations

- leak detection pits

- cribs and other facilities for liquid disposal to ground

- direct buried piping, encased piping, and ventilation duct work

- pump pits, sluice pits, and valve pits associated with individual tanks

- other valve pits, jumper pits, diversion boxes, and associated structures 
AX Tank Farm Ancillary Equipment Study provides estimates of quantities of lightly and heavily contaminated debris that would be produced from demolition, removal, and loadout of all ancillary equipment items from AX Tank Farm. The majority of waste material produced would be Category 1 LLW by classification, which would be sent to ERDF for disposal. Some Category 3 contaminated equipment would be derived from demolition of surplus buildings and facilities. This equipment would be packaged appropriately and sent to the low-level (waste burial) ground (LLBG). Heavily contaminated material that would have to be sent to the NTF (because there is no viable disposal option) will be derived from removal of process waste piping and demolition of various pits and boxes. Bounding estimates of the inventories of chemicals and radionuclides associated with individual equipment components are provided in Appendix B of the AX Tank Farm Ancillary Equipment Study.

In the report, it is proposed that as process waste piping is exposed in trench excavations, it would be sheared into manageable lengths (i.e., lengths of approximately $10 \mathrm{ft}$.) and loaded into shielded boxes using hydraulic shears and grapple implements. Contaminated piping is expected to make up the majority of the material in the ancillary equipment waste stream going to the NTF. The heavily contaminated debris derived from demolition of pits and boxes would be of two principal types: (1) scabbling waste and (2) metal waste. Scabbling waste would be generated from an initial decontamination step that would be applied to the inside surfaces of most unlined pits and boxes in the farm. It is anticipated that scabbling would eliminate the majority of contamination from pits and boxes in advance of demolition. Scabbling waste would be in the form of pulverized concrete with a top size of $3 / 8$ in. to $1 / 4$ in. Metal waste would consist of embedded pipe stubs, jumpers, nozzles, drains, liner sheet scrap (a few pits have metal liners), pumps, pump and jumper supports, and casings, etc. recovered during pit demolition. Summary descriptions of the materials in the ancillary equipment waste stream are given below:

The expected composition of materials in the ancillary equipment waste stream going to the NTF is as follows:

Process waste piping and ventilation duct work:

$$
5,720 \mathrm{ft}^{3}
$$

120 containers

Scabbling waste (pulverized concrete):

Metal waste from pits:

$$
153 \mathrm{ft}^{3}
$$$$
2,814 \mathrm{ft}^{3}
$$

3 containers

60 containers

Best estimates of hazardous and radiological constituents in process waste piping and belowground ventilation elements are identified in Tables $6 \mathrm{a}, 6 \mathrm{~b}$, and $6 \mathrm{c}$ of Appendix B, HNF-3441. Information from the source tables is reproduced in Tables 2.3 and 2.4. The source tables include some lengths of piping that would be left in place around the perimeter of the AX Tank Farm, pending closures of adjacent tank farms. The entries in Tables 2.3 and 2.4 reflect only those lengths of piping that would be removed as part of closure of the AX Tank Farm. For purposes of estimating contaminant inventories in scabbling waste and metal waste from pits and boxes, it is assumed that the combined inventory retained in the two waste forms will equal 95 
percent of the original best estimate inventories for contaminated pits, boxes, and tanks listed in Tables $6 \mathrm{e}$ and $6 \mathrm{f}$ in Appendix B of HNF-3441. Chemical and radiological constituents from pits and boxes are summarized in Tables 2.3 and 2.4 .

The same specially designed containers used to loadout base slab debris during tank removal would be used to transport ancillary equipment debris. Specific activity levels of ${ }^{137} \mathrm{Cs}$ in this debris have not been evaluated but could vary over wide limits. However, activity levels would likely be of the same order of magnitude as those predicted for base slab debris. 
Table 2-1. Best Estimates of Nonradiological Inventories in Base Slab Debris from Tank Removal (in kg)

\begin{tabular}{|c|c|c|c|c|c|}
\hline Analyte & AX-101 & $A X-102$ & AX-103 & AX-104 & Total (kg) \\
\hline $\mathrm{Ag}$ & 0.0000 & NR & 0.0000 & NR & 0.0000 \\
\hline$\overline{\mathrm{Al}}$ & 2.271 .9262 & 580.9498 & 681.5779 & 685.7827 & $4,220.2365$ \\
\hline As & NR & NR & NR & NR & 0.0000 \\
\hline B & NR & NR & 0.0000 & NR & 0.0000 \\
\hline $\mathrm{Ba}$ & 97.9966 & NR & 29.3990 & 29.3990 & 156.7945 \\
\hline$\overline{\mathrm{Bi}}$ & 0.0000 & 0.0000 & 0.0000 & NR & 0.0000 \\
\hline $\mathrm{Ca}$ & 929.5551 & 81.1448 & 262.1029 & 263.5255 & $1,536.3282$ \\
\hline $\mathrm{Cd}$ & 57.2957 & NR & 17.1887 & 17.1887 & 91.6732 \\
\hline $\mathrm{Cl}$ & 19.3922 & 12.7320 & 6.4538 & 41.9946 & 80.5726 \\
\hline $\mathrm{TIC}$ as $\mathrm{CO} 3$ & 208.7726 & 325.7662 & 125.9794 & 148.7147 & 809.2330 \\
\hline $\mathrm{Cr}$ & 107.7770 & 2.5953 & 32.3331 & 32.3331 & 175.0384 \\
\hline $\mathrm{Cu}$ & NR & NR & 0.0000 & NR & 0.0000 \\
\hline $\mathbf{F}$ & NR & 0.0000 & 0.0000 & NR & 0.0000 \\
\hline $\overrightarrow{\mathrm{Fe}}$ & $10,803.8713$ & $\mathrm{t}, \mathbf{4 5 0 . 0 0 3 9}$ & $3,023.0255$ & $3,039.7896$ & $18,316.6903$ \\
\hline $\mathrm{Hg}$ & 0.0000 & 0.0000 & 0.0000 & NR & 0.0000 \\
\hline $\mathrm{K}$ & 4.6493 & 3.0676 & 0.0000 & $1,354.6135$ & $1,362.3304$ \\
\hline $\mathrm{La}$ & NR & 0.0000 & 0.0000 & $\mathrm{NR}$ & 0.0000 \\
\hline $\mathrm{Mg}$ & 141.2271 & $\mathrm{NR}$ & 42.3681 & 42.3681 & 225.9633 \\
\hline Mn & 157.7451 & 121.6662 & 65.0878 & 47.3235 & 391.8225 \\
\hline $\mathrm{Na}$ & $4,113.9745$ & $1,715.7021$ & 779.7132 & 943.9144 & $7,553.3042$ \\
\hline $\mathrm{Ni}$ & 518.6061 & 64.3388 & 155.5818 & 155.5818 & 894.1086 \\
\hline $\mathrm{NO} 2$ & 391.3358 & 194.1024 & 38.9256 & 39.2977 & 663.6614 \\
\hline $\mathrm{NO} 3$ & $2,591.5366$ & $1,311.2090$ & 0.0000 & 782.1005 & $4,684.8461$ \\
\hline $\mathrm{OH}$ & $9,702.0420$ & $1,192.3677$ & $2,704.6272$ & $4,469.1456$ & $18,068.1826$ \\
\hline $\mathrm{Pb}$ & 0.0000 & 0.0345 & 0.0000 & 41.9946 & 42.0290 \\
\hline $\mathrm{P}$ as $\mathrm{PO} 4$ & 354.9862 & 22.9665 & 106.4959 & 107.1054 & 591.5540 \\
\hline$P$ & 115.7745 & 3.0992 & 34.7323 & 34.7323 & 188.3383 \\
\hline $\mathrm{Se}$ & NR & NR & NR & NR & 0.0000 \\
\hline $\mathrm{Si}$ & $2,887.5267$ & 359.6466 & 711.4690 & 716.6044 & $4,675.2468$ \\
\hline $\mathrm{S}$ as $\mathrm{SO} 4$ & 526.5928 & 36.3772 & 132.1944 & 132.1944 & 827.3588 \\
\hline $\mathrm{S}$ & 175.7546 & 5.0206 & 44.1209 & 44.1209 & 269.0171 \\
\hline $\mathrm{Sr}$ & 0.0000 & 50.9010 & 0.0000 & 11.1729 & 62.0739 \\
\hline TOC & 536.8712 & 10.7231 & 0.0000 & NR & 547.5943 \\
\hline Total U & 0.0330 & 15.9135 & 2.9769 & 0.0433 & 18.9667 \\
\hline $\mathrm{Zn}$ & NR & NR & 0.0000 & NR & 0.0000 \\
\hline $\mathrm{Zr}$ & 0.0000 & 0.0000 & 0.0000 & NR & 0.0000 \\
\hline EDTA & 384.5268 & 0.0000 & 0.0000 & NR & 384.5268 \\
\hline $\mathrm{NH3}$ & 23.2367 & 7.0404 & 39.6028 & NR & 69.8799 \\
\hline $\mathrm{Cr}+6$ & NR & NR & NR & NR & 0.0000 \\
\hline $\mathrm{CN}$ & NR & NR & NR & NR & 0.0000 \\
\hline $\mathrm{H} 2 \mathrm{O}$ & $33,230.2758$ & $7,425.7745$ & $7,523.2207$ & $7,523.2207$ & $55,702.4917$ \\
\hline
\end{tabular}


HNF-4098, Rev. 0

Table 2-2. Best Estimates of Radiological Inventories in Base Slab Debris from Tank Removal (in curies)

\begin{tabular}{|c|c|c|c|c|c|}
\hline Analyte & AX-101 & AX-102 & AX-103 & AX-104 & Totals (Ci) \\
\hline $3 \mathrm{H}$ & 0.8461 & 0.3293 & 1.1017 & 1.3022 & 3.5794 \\
\hline $14 \mathrm{C}$ & 0.0690 & 0.1016 & 0.0000 & 0.2427 & 0.4133 \\
\hline $59 \mathrm{Ni}$ & 6.2184 & 0.4924 & 1.0186 & 1.2020 & 8.9315 \\
\hline $60 \mathrm{Co}$ & 0.1397 & 0.2439 & 60.5740 & 60.5740 & 121.5316 \\
\hline $63 \mathrm{Ni}$ & 611.7357 & 51.1679 & 102.1851 & 120.5899 & 885.6786 \\
\hline $79 \mathrm{Se}$ & 3.4660 & 1.8505 & 0.9632 & 1.1366 & 7.4162 \\
\hline $90 \mathrm{Sr}$ & $97,593.3700$ & $51,891.3141$ & $524,979.8032$ & $524,979.8032$ & $1,199, \mathbf{4 4 4 . 2 9 0 0}$ \\
\hline $90 Y$ & $97,593.3700$ & $51,891.3141$ & $524,979.8032$ & $524,899.8689$ & $1,199,364.3560$ \\
\hline $93 \mathrm{mNb}$ & 12.8445 & 5.3476 & 3.3247 & 3.9298 & 25.4466 \\
\hline $93 \mathrm{Zr}$ & 14.9751 & 8.0791 & 4.4166 & 5.2397 & 32.7105 \\
\hline $99 \mathrm{Tc}$ & 0.4659 & 0.6733 & 0.0000 & 1.7222 & 2.8613 \\
\hline 106Ru & 0.0268 & 0.2247 & 0.0033 & 0.0039 & 0.2587 \\
\hline $113 \mathrm{mCd}$ & 31.9074 & 40.3957 & 18.9051 & 22.4228 & 113.6310 \\
\hline $125 \mathrm{Sb}$ & 0.8247 & 1.5235 & 24.1222 & 24.1222 & 50.5926 \\
\hline $126 \mathrm{Sn}$ & 5.5660 & 2.9316 & 1.5026 & 1.7761 & 11.7763 \\
\hline 129I & 0.0009 & 0.0013 & 0.0000 & 0.0033 & 0.0055 \\
\hline $134 \mathrm{Cs}$ & 0.0995 & 0.0117 & 0.0675 & 0.0798 & 0.2585 \\
\hline $135 \mathrm{Cs}$ & NR & $\mathrm{NR}$ & $\overline{N R}$ & $\overline{\mathrm{NR}}$ & 0.0000 \\
\hline $137 \mathrm{Cs}$ & $1,800.9754$ & $7,174,8814$ & $10,890.0823$ & $10,890.0823$ & $30,756.0214$ \\
\hline $137 \mathrm{mBa}$ & $1,703.7228$ & $6,787.4378$ & $10,302.0178$ & $10,302.0178$ & $29,095.1962$ \\
\hline $151 \mathrm{Sm}$ & $12,961.3981$ & $5,329.6907$ & $3,585.4430$ & $4,237.9829$ & $26,114.5148$ \\
\hline 152Eu & 3.2417 & 7.8483 & 1.0968 & 1.2945 & 13.4813 \\
\hline $154 \mathrm{Eu}$ & 76.1803 & 600.1644 & 442.1659 & 442.1659 & $1,560.6766$ \\
\hline $155 \mathrm{Eu}$ & 198.6722 & 380.4889 & 284.1697 & 284.1697 & $1,147.5004$ \\
\hline $226 \mathrm{Ra}$ & 0.0004 & 0.0001 & 0.0001 & 0.0001 & 0.0006 \\
\hline $227 \mathrm{Ac}$ & 0.0022 & 0.0004 & 0.0003 & 0.0004 & 0.0033 \\
\hline $228 \mathrm{Ra}$ & 0.0000 & 0.0000 & 0.0000 & 0.0000 & 0.0000 \\
\hline $229 \mathrm{Th}$ & 0.0000 & 0.0000 & 0.0000 & 0.0000 & 0.0000 \\
\hline $231 \mathrm{~Pa}$ & 0.0032 & 0.0000 & 0.0008 & 0.0009 & 0.0049 \\
\hline $232 \mathrm{Th}$ & 0.0000 & 0.0000 & 0.0000 & 0.0000 & 0.0000 \\
\hline $232 \mathrm{U}$ & 0.0000 & 0.0000 & 0.0000 & 0.0000 & 0.0000 \\
\hline $233 \mathrm{U}$ & 0.0000 & 0.0000 & 0.0000 & 0.0000 & 0.0000 \\
\hline $234 \mathrm{U}$ & 0.0004 & 0.0006 & 0.0009 & 0.0011 & 0.0029 \\
\hline $235 \mathrm{U}$ & 0.0000 & 0.0000 & 0.0000 & 0.0000 & 0.0001 \\
\hline $236 \mathrm{U}$ & 0.0000 & 0.0000 & 0.0000 & 0.0000 & 0.0001 \\
\hline $237 \mathrm{~Np}$ & 0.0015 & 0.0022 & 0.0031 & 0.0037 & 0.0104 \\
\hline $238 \mathrm{Pu}$ & 4.8626 & 23.2756 & 0.8149 & 0.9632 & 29.9162 \\
\hline $238 \mathrm{U}$ & 0.0003 & 0.0004 & 0.0009 & 0.0010 & 0.0026 \\
\hline $239 \mathrm{Pu}$ & 130.4433 & 157.3508 & 21.0237 & 24.9270 & 333.7449 \\
\hline $240 \mathrm{Pu}$ & 24.2415 & 56.5540 & 4.0255 & 4.7388 & 89.5598 \\
\hline $239 / 240 \mathrm{Pu}$ & 154.6848 & 213.9048 & 134.2687 & 134.2687 & 637.1269 \\
\hline $241 \mathrm{Am}$ & 146.8863 & 507.8314 & 0.0000 & 39.2977 & 694.0154 \\
\hline $241 \mathrm{Pu}$ & 344.4779 & $1,608.1329$ & 58.0190 & 68.5783 & $2,079.2080$ \\
\hline $242 \mathrm{Cm}$ & 0.1233 & 0.6771 & 0.0303 & 0.0358 & 0.8666 \\
\hline $242 \mathrm{mAm}$ & NR & $\mathrm{NR}$ & NR & NR & 0.0000 \\
\hline $242 \mathrm{Pu}$ & 0.0020 & 0.0117 & 0.0003 & 0.0004 & 0.0144 \\
\hline $243 \mathrm{Am}$ & 0.0077 & 0.0569 & 0.0010 & 0.0012 & 0.0669 \\
\hline
\end{tabular}


HNF-4098, Rev. 0

\begin{tabular}{|c|c|c|c|c|c|}
\hline Analyte & AX-101 & AX-102 & AX-103 & AX-104 & Totals (Ci) \\
\hline $243 \mathrm{Cm}$ & 0.0111 & 0.0831 & 0.0023 & 0.0028 & 0.0993 \\
\hline $244 \mathrm{Cm}$ & 0.4506 & 3.4394 & 0.0715 & 0.0844 & 4.0459 \\
\hline
\end{tabular}

Decay Date: $12 / 31 / 99$ 
HNF-4098, Rev. 0

Table 2-3. Best Estimates of Nonradiological Inventories in Heavily Contaminated Debris from Ancillary Equipment Removal (in kg)

\begin{tabular}{|c|c|c|c|}
\hline Analyte & $\begin{array}{c}\text { Process Waste } \\
\text { and Vent Piping }\end{array}$ & $\begin{array}{l}\text { Pits, Boxes } \\
\text { and Tanks }\end{array}$ & Totals (kg) \\
\hline $\mathrm{Ag}$ & 0.0000 & 0.0000 & 0.0000 \\
\hline $\mathrm{Al}$ & 100.6455 & 205.2056 & 305.8510 \\
\hline As & 0.0000 & 0.0000 & 0.0000 \\
\hline B & 0.0000 & 0.0000 & 0.0000 \\
\hline$\overline{\mathrm{Ba}}$ & 3.2565 & 5.8636 & 9.1201 \\
\hline $\mathbf{B i}$ & 0.0001 & 0.0016 & 0.0018 \\
\hline $\mathrm{Ca}$ & 33.9592 & 70.6403 & 104.5995 \\
\hline $\mathrm{Cd}$ & 1.9040 & 3.4283 & 5.3322 \\
\hline $\mathrm{Cl}$ & 1.9555 & 4.3406 & 6.2961 \\
\hline $\mathrm{TIC}$ as $\mathrm{CO} 3$ & 20.3532 & 52.7238 & 73.0770 \\
\hline $\mathrm{Cr}$ & 3.6947 & 6.7769 & 10.4716 \\
\hline $\mathrm{Cu}$ & 0.0000 & 0.0000 & 0.0000 \\
\hline $\mathrm{F}$ & 0.0005 & 0.0065 & 0.0070 \\
\hline $\mathrm{Fe}$ & 406.3872 & 765.9242 & $1,172.3114$ \\
\hline $\mathrm{Hg}$ & 0.0000 & 0.0000 & 0.0000 \\
\hline $\mathrm{K}$ & 27.2847 & 54.8822 & 82.1669 \\
\hline $\mathrm{La}$ & 0.0000 & 0.0000 & 0.0000 \\
\hline $\mathrm{Mg}$ & 4.6930 & 8.4503 & 13.1433 \\
\hline $\mathrm{Mn}$ & 10.4427 & 15.4381 & 25.8808 \\
\hline$\overline{\mathrm{Na}}$ & 186.3005 & 404.2244 & 590.5249 \\
\hline $\mathrm{Ni}$ & 22.4572 & 69.6393 & 92.0964 \\
\hline $\mathrm{NO} 2$ & 17.1455 & 44.3287 & 61.4742 \\
\hline NO3 & 104.2518 & 166.7700 & 271.0218 \\
\hline $\mathrm{OH}$ & 380.8297 & 822.0258 & $1,202.8555$ \\
\hline $\mathrm{Pb}$ & 0.8409 & 1.6879 & 2.5288 \\
\hline $\mathrm{P}$ as $\mathrm{PO} 4$ & 12.7134 & 22.9053 & 35.6188 \\
\hline $\mathrm{P}$ & 3.9802 & 7.2862 & 11.2664 \\
\hline $\mathrm{Se}$ & 0.0000 & 0.0000 & 0.0000 \\
\hline $\mathrm{Si}$ as $\mathrm{SiO} 3$ & 104.2501 & 224.7285 & 328.9786 \\
\hline $\mathrm{S}$ as $\mathrm{SO} 4$ & 31.5168 & 211.6355 & 243.1523 \\
\hline $\mathrm{S}$ & 10.2560 & 70.3494 & 80.6504 \\
\hline $\mathrm{Sr}$ & 2.1029 & 2.4902 & 4.5931 \\
\hline TOC & 9.2787 & 24.7207 & 33.9994 \\
\hline Total U & 1.0016 & 4.6094 & 5.6111 \\
\hline $\mathrm{Zn}$ & 0.0000 & 0.0000 & 0.0000 \\
\hline $\mathrm{Zr}$ & 0.0000 & 0.0001 & 0.0001 \\
\hline EDTA & 6.2249 & 15.6464 & 21.8713 \\
\hline $\mathrm{NH} 3$ & 2.2845 & 4.6082 & 6.8926 \\
\hline $\mathrm{Cr}+6$ & 0.0000 & 0.0000 & 0.0000 \\
\hline $\mathrm{CN}$ & 0.0000 & 0.0000 & 0.0000 \\
\hline $\mathrm{H} 2 \mathrm{O}$ & 917.0230 & $2,075.7411$ & $2,992.7640$ \\
\hline
\end{tabular}


Table 2-4. Best Estimates of Radiological Inventories in Heavily Contaminated Debris from Ancillary Equipment Removal (in curies)

\begin{tabular}{|c|c|c|c|}
\hline Analyte & $\begin{array}{c}\text { Process Waste } \\
\text { and Vent Piping }\end{array}$ & $\begin{array}{l}\text { Pits, Boxes } \\
\text { and Tanks }\end{array}$ & Totals (Ci) \\
\hline $3 \mathrm{H}$ & 0.0969 & 0.1830 & 0.2800 \\
\hline $14 \mathrm{C}$ & 0.0101 & 0.0217 & 0.0319 \\
\hline $59 \mathrm{Ni}$ & 0.1933 & 0.5099 & 0.7032 \\
\hline $60 \mathrm{Co}$ & 3.6285 & 6.1568 & 9.7853 \\
\hline $63 \mathrm{Ni}$ & 19.1899 & 49.8489 & 69.0388 \\
\hline $79 \mathrm{Se}$ & 0.1905 & 0.3860 & 0.5765 \\
\hline $90 \mathrm{Sr}$ & $35,175.9620$ & $63,479.4315$ & $98,655.3936$ \\
\hline $90 \mathrm{Y}$ & $35,174.3643$ & $63,476.2266$ & $98,650.5909$ \\
\hline $93 \mathrm{mNb}$ & 0.6256 & 1.2228 & 1.8484 \\
\hline $93 \mathrm{Zr}$ & 0.8441 & 1.7140 & 2.5581 \\
\hline $99 \mathrm{Tc}$ & 0.0695 & 0.1500 & 0.2195 \\
\hline $106 \mathrm{Ru}$ & 0.0089 & 0.0103 & 0.0192 \\
\hline $113 \mathrm{mCd}$ & 3.2873 & 6.0097 & 9.2970 \\
\hline $125 \mathrm{Sb}$ & 1.5104 & 2.5442 & 4.0546 \\
\hline $126 \mathrm{Sn}$ & 0.3015 & 0.6107 & 0.9122 \\
\hline 1291 & 0.0001 & 0.0003 & 0.0004 \\
\hline $134 \mathrm{Cs}$ & 0.0062 & 0.0109 & 0.0172 \\
\hline $135 \mathrm{Cs}$ & 0.0000 & 0.0000 & 0.0000 \\
\hline $137 \mathrm{Cs}$ & 944.6089 & $1,467.8086$ & $2,412.4175$ \\
\hline $137 \mathrm{mBa}$ & 892.6076 & $1,386.5564$ & $2,279.1640$ \\
\hline $151 \mathrm{Sm}$ & 648.1854 & $1,317.4025$ & $1,965.5879$ \\
\hline 152Eu & 0.4280 & 0.7745 & 1.2025 \\
\hline 154Eu & 50.5547 & 81.7730 & 132.3277 \\
\hline $155 \mathrm{Eu}$ & 34.6263 & 57.1722 & 91.7985 \\
\hline $226 \mathrm{Ra}$ & 0.0000 & 0.0000 & 0.0000 \\
\hline $227 \mathrm{Ac}$ & 0.0001 & 0.0002 & 0.0002 \\
\hline $228 \mathrm{Ra}$ & 0.0000 & 0.0000 & 0.0000 \\
\hline 229Th & 0.0000 & 0.0000 & 0.0000 \\
\hline $231 \mathrm{~Pa}$ & 0.0001 & 0.0002 & 0.0003 \\
\hline $232 \mathrm{Th}$ & 0.0000 & 0.0000 & 0.0000 \\
\hline $232 \mathrm{U}$ & 0.0000 & 0.0002 & 0.0002 \\
\hline $233 \mathrm{U}$ & 0.0001 & 0.0008 & 0.0008 \\
\hline $234 \mathrm{U}$ & 0.0002 & 0.0016 & 0.0017 \\
\hline $235 \mathrm{U}$ & 0.0000 & 0.0001 & 0.0001 \\
\hline $236 \mathrm{U}$ & 0.0000 & 0.0001 & 0.0001 \\
\hline $237 \mathrm{~Np}$ & 0.0003 & 0.0006 & 0.0009 \\
\hline $238 \mathrm{Pu}$ & 1.0438 & 1.9147 & 2.9585 \\
\hline $238 \mathrm{U}$ & 0.0002 & 0.0014 & 0.0016 \\
\hline 239Pu & 9.7416 & 20.1434 & 29.8849 \\
\hline $240 \mathrm{Pu}$ & 7.7912 & 15.0567 & 22.8479 \\
\hline $239 / 240 \mathrm{Pu}$ & 23.9621 & 46.0818 & 70.0439 \\
\hline 241Am & 23.0854 & 43.0099 & 66.0953 \\
\hline $241 \mathrm{Pu}$ & 71.5411 & 122.2445 & 193.7856 \\
\hline $242 \mathrm{Cm}$ & 0.0288 & 0.0341 & 0.0629 \\
\hline $242 \mathrm{mAm}$ & 0.0000 & 0.0000 & 0.0000 \\
\hline $242 \mathrm{Pu}$ & 0.0005 & 0.0009 & 0.0015 \\
\hline
\end{tabular}


HNF-4098, Rev. 0

\begin{tabular}{|c|c|c|c|}
\hline Analyte & $\begin{array}{c}\text { Process Waste } \\
\text { and Vent Piping }\end{array}$ & $\begin{array}{c}\text { Pits, Boxes } \\
\text { and Tanks }\end{array}$ & Totals (Ci) \\
\hline $243 \mathrm{Am}$ & 0.0024 & 0.0043 & 0.0067 \\
\hline $243 \mathrm{Cm}$ & 0.0036 & 0.0063 & 0.0099 \\
\hline $244 \mathrm{Cm}$ & 0.1448 & 0.2418 & 0.3866 \\
\hline
\end{tabular}

Decay Date: $12 / 31 / 99$ 
HNF-4098, Rev. 0

\subsection{PROCESS DESCRIPTION}

\subsection{INTRODUCTION AND APPROACH}

This section provides a summary of background information, general process knowledge, and rationale that were applied in conceptualizing the process logic for the new treatment facility.

Carbon and stainless steels do not interact chemically with tank waste to any appreciable extent. Process waste piping and tank liner plate in the waste feed may be heavily contaminated, though it is expected that contamination will be a surface-adhesion problem almost exclusively. Experience has shown that a dilute acid solution will dissolve the scale and oxide compounds making up the matrix in which the radiological and non-radiological contaminants reside. Hypothetically, after the steel is removed from the acid solution, it should be free of all contamination. As a practical matter, deposition of contamination in small pits and crevices (where reagent access is constrained) and issues that affect rinsing efficiency will tend to prevent perfect decontamination. Based on these considerations, an acid-etch and water-rinse process is envisioned that is expected to provide a large decontamination factor for the free metal in the waste feed.

As indicated in Section 2, the waste feed will include coarse concrete debris from the four $\mathrm{AX}$ tanks, fine concrete debris (scabbling waste) from pits and boxes, and grout rubble from the 1-ft. thick layer of shielding material poured into the tanks prior to demolition. Concrete and grout are capable of interacting with tank waste constituents. Cementitious materials act as porous media in which strontium, cesium, and other radioisotopes can be taken up and retained in the cement matrix. The depth to which contaminants can penetrate exposed concrete is ordinarily limited to a small fraction of an inch, provided that the concrete is free of surface defects, such as cracks, microchannels, or large pores. Mineral aggregates (sand and gravel) in concrete generally do not exhibit significant reactivity with tank waste. Contaminants can sorb onto the surfaces of mineral grains, either in concrete or in loose soil. Sheet silicate minerals (e.g., micas and clay minerals) can take up and retain some contaminants as inter-layer cations.

The proposed treatment process will include an autogenous grinding step to physically abrade away contaminated surfaces from coarse soil and cementitious rubble material. Grinding will be followed by a radiological survey step for coarse solids. Material with acceptably low levels of radiological contamination will be released for disposal as Category $1 \mathrm{LLW}$. Material with unacceptably high levels of contamination (i.e., solids that fail the release survey step) will be returned for additional grinding. The fines from autogenous grinding (consisting of a mixture of sand-size particles of cement and silicate mineral matter) will be diverted to an acid digestion step to break down the cement. The insoluble residues (i.e., the fine mineral matter) will be turned into a concreted waste form and disposed as Category $3 \mathrm{LLW}$. Contaminants in solution will be forwarded to DSTs.

Index factors were carried through the material balance calculations (see Appendix A) to aid in visualizing the results of various decontamination factors and unit operations within the overall process. Cat- 1 and Cat- 3 indices are defined in terms of the ratio of Curies per unit volume in a given stream to Category 1 and 3 limits identified in the Hanford Site Solid Waste Acceptance Criteria (FDH 1998). An index value of 0.999 or less indicates that a given stream is within the 
designated category limit. In a similar manner, the TRU index is defined as the ratio of TRU per gram to the limit of $100 \mathrm{nCi} /$ gram prescribed in DOE Order 5820.2A.

\subsection{FEED STREAMS}

The incoming waste feed for the process was subdivided into a number of streams of distinct material types to facilitate calculations and process description. They are identified as Streams 101 through 107 on the Process Flowsheet (Figure 3.1) and in the material balance (Appendix A). The given information for this study regarding compositions, masses and volumes, and chemical and radiological inventories of the waste feed is summarized in Section 2.

At the head end of the process, the seven material streams are segregated into two groups for processing. The first group is made up of metal, including Ancillary Metal (Stream 102), which consists of process waste piping and metal scrap from demolition of pits, auxiliary tanks and diversion boxes, and Tank Metal (Stream 105), consisting of liner plate scrap from the four AX tanks. The segregated metal moves through a set of processing steps that is distinct from the second group. The second group is made up of "rubble", consisting of Ancillary Scabbling Waste (Stream 101), Tank Soil (Stream 103), Tank Concrete (Stream 104), Tank Grout (Stream 106), and Residual Tank Waste (Stream 107), as described in Section 2.

A set of enabling assumptions was made regarding the distribution of residual tank waste constituents (listed in Tables 2.1 and 2.2) among Streams 103 - 107. Collectively, these five streams make up the base slab debris from demolition of tanks. The mass of residual tank waste in base slab debris is assigned to Stream 107. It is expected that, up until the time that tanks are demolished, most residual waste will remain as an intact layer of hard heel material on the floor of the tanks. When the tanks are demolished, it is expected that the hard heel material will arrive at the waste treatment facility as a thick coating adhering to tank liner scrap and as detached lumps of various sizes mixed in with concrete, grout, and soil. The chemical and radiological inventory in residual tank waste was allocated to the five base slab debris streams as follows:

\begin{tabular}{lr} 
Stream & Percent of Inventory \\
\hline Tank Soil (Stream 103) & $0.5 \%$ \\
Tank Concrete (Stream 104) & $0.5 \%$ \\
Tank Metal (Stream 105) & $1.5 \%$ \\
Tank Grout (106) & $2.5 \%$ \\
Residual Tank Waste (107) & $95 \%$
\end{tabular}

As indicated in Section 2, demolition waste from ancillary equipment includes metal (process waste pipe and metal waste from pits, boxes and tanks) and non-metal (pulverized concrete scabbling waste from pits, boxes and tanks). Based on the manner in which the chemical and radiological inventory estimates for ancillary equipment is presented in Tables 2.3 and 2.4, it is unclear how the inventories should be distributed between Ancillary Scabbling Waste (Stream 101) and Ancillary Metal (Stream 102). For material balance calculations, another enabling assumption was made that the inventory in ancillary equipment debris would be distributed equally between Streams 101 and 102 . 
Figure 3-1. New Treatment Facility Flowsheet

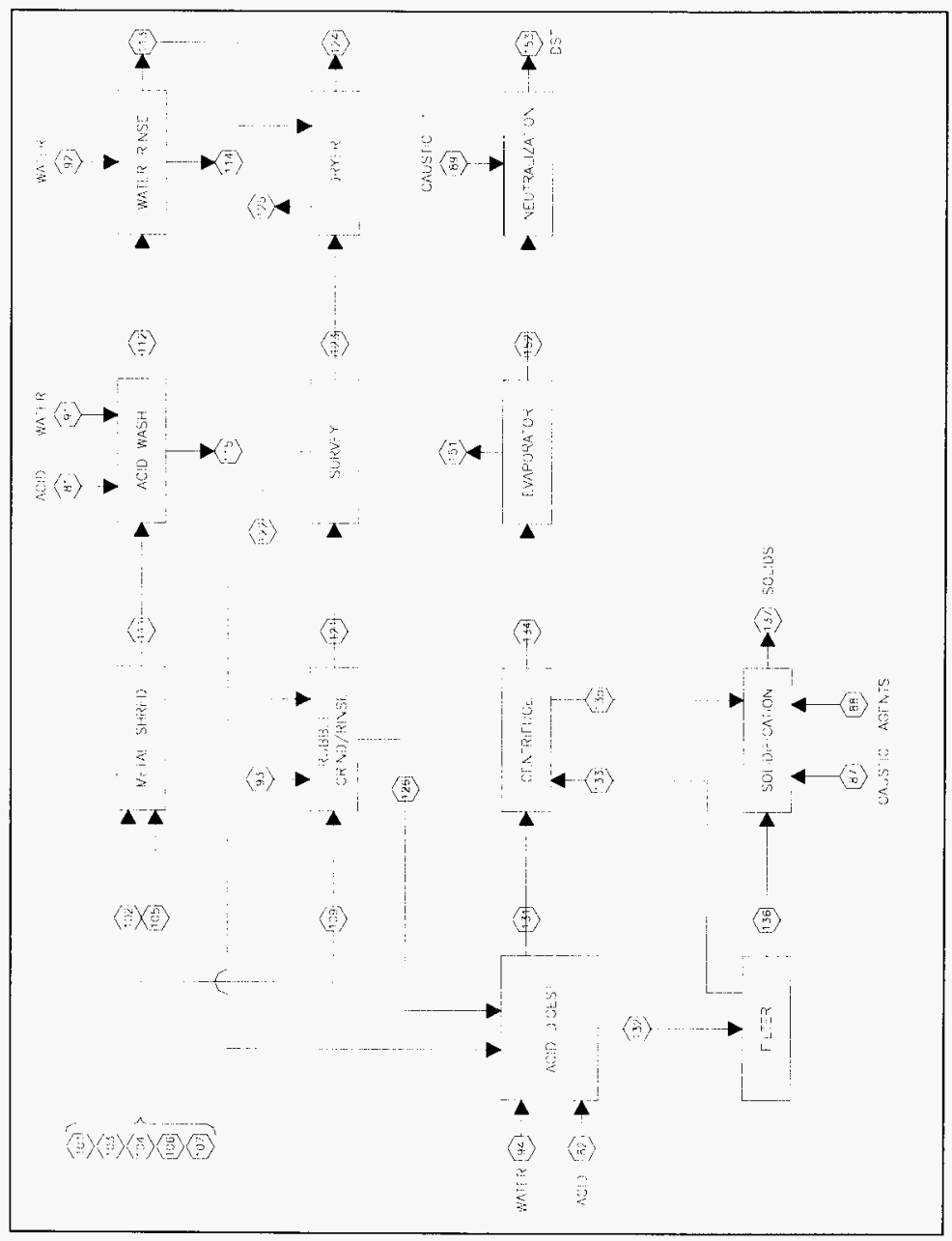




\subsection{METAL WASTE PROCESSING}

The initial processing step for metal streams is shredding. Shredding will make the inside surfaces of pipe more accessible to etching and rinse solutions. A uniform fragment size also will facilitate material handling in subsequent process steps. The next step is immersion (washing) in dilute nitric acid. The time and temperature are controlled to allow full dissolution of all scale and dissolution of some metal (1\% loss of the metal is assumed for material balance purposes). Virtually all of the residual tank waste contamination associated with Stream 111 is assumed to be in the liquid phase (Stream 115) following this processing step. Contamination carried forward in Steam 112 is a function of solution drag-out from the wash process (residual droplets of the acid wash solution adhering to the metal). Although not specifically shown, the dilution water (Stream 91) for the acid wash operation is identified in the material balance as a combination of rinse return water (Stream 114) and evaporator condensate (Stream 151).

After acid washing, metal will be rinsed with fresh (not recycled) water (Stream 92). As it is conveyed from the rinse area to the dryer, the material in Stream 113 will be surveyed with radiation detectors to verify that it is acceptable for disposal as Category $1 \mathrm{LLW}$. A small fraction of material in Stream 113 is expected to fail the survey. Reject metal in Stream 113 will be recycled back to the acid wash step (no assigned stream number). At the dryer, Stream 113 is combined with Stream 123, dried, and loaded into 20-ton RO/RO containers for shipment to ERDF for disposal (Stream 124).

\subsection{RUBBLE}

The initial processing step for the combined rubble stream (Steam 109) is autogenous milling (wet grinding). The fines (sand-size material and smaller) and soluble waste in Stream 109 will immediately go into the underflow, rubble fines (Stream 126), from the mill. After it is discharged from the mill, the coarse fraction (Stream 121- consisting of coarse soil and concrete aggregate) will move to a radiation survey step. Some fraction of the material in Stream 121 will fail the survey step the first time through and will be cycled back to the grinding mill for further attrition. For material balance calculation purposes, it was assumed that a relatively small percentage of material in Stream 121 would need to be recycled. Examination of the composition of the wet rubble (Stream 123) shows that the only way it is likely to meet the Category 1 limits for LLW disposal is for essentially all of the contaminated cement to be stripped away. The released rubble (Stream 123) is combined with the washed metal stream, dried, and loaded into containers for shipment to ERDF.

\subsection{ACID DIGESTION}

The slurry (Stream 126) containing the cement and sand fines from wet grinding is fed to the acid digester. The digester also receives the underflow, metal wash return (Stream 115), from the metal acid washing step. Sufficient additional acid is supplied to maintain concentration and dissolve essentially all (99\%) of the cement. The resulting sand slurry, digester underflow (Stream 132), is sent to a filter to remove most of the carrier solution. The filter cake (Steam 136 ) is surveyed to confirm its radiological status and is then routed to solidification. 
The digester overflow (Stream 131) and the filter liquor (Stream 133) go to a centrifuge for clarification. The small amount of centrifuge cake (Stream 135) is surveyed to confirm status and is then routed to solidification. The centrifuge overflow (Stream 134) is essentially pure solution, free of any entrained solids, and is suitable for evaporation.

Streams 135 and 136 are combined for solidification as Category 3 low-level mixed waste (LLMW). Caustic is added to neutralize the acid values of the entrained liquids. The neutralized solids are mixed with Portland cement powder to give a solid product that will meet Category 3 waste stabilization criteria. Since most of the contamination is expected to be associated with the residual moisture in the solids, it might be argued that the solids could be rinsed further with the objective of meeting Category 1 limits. Certainly, standard methods of operation for both filters and centrifuges can involve single or multiple rinse cycles. However, to meet Category 1 limits, rinsing would have to provide an additional decontamination factor of at least 10,000 . That could be difficult to achieve if the solids are difficult to filter efficiently. It is unclear whether the reduction in disposal costs would be sufficient to offset the costs of incorporating the additional counter-current rinse/filter equipment into the process.

\subsection{EVAPORATION}

The evaporator receives the centrifuge overflow and removes about 60 percent of the incoming liquid volume as evaporator condensate (Stream 151). The evaporator bottoms (Stream 152) is a concentrated solution that may contain a small amount of precipitated solids. Sufficient caustic is added to meet DST specifications, yielding DST returns (Stream 153). In the proposed sequence, the feed is neutralized after evaporation rather than before. The opposite sequence may be used and there are arguments concerning overhead composition and precipitated solids in the evaporator that would affect this scheme. The amounts and compositions of the condensate and returns would not be affected at this level of detail by the pre/post neutralization decision.

A percentage of the evaporator condensate can be reused without treatment as dilution water (Stream 91) to the acid washing step. Even with some amount of reuse, a significant quantity (perhaps as much as 4.8 million liters or 1.2 million gallons) of lightly contaminated water in Stream 151 would require on-site or off-site treatment. With refinements to the flowsheet (e.g., addition of an ion exchange process step), it may be possible to show "zero" output of contaminated waste water from the process. However, that issue is beyond the scope of the present study.

\subsection{PROCESS OUTPUTS}

As a result of processing heavily contaminated tank farm debris through the proposed NTF, all solid and liquid waste generated by the process would be in forms that are compatible with existing on-site treatment/disposal options. The principal outputs are Category 1 LLW, Category $3 \mathrm{LLW}$, and concentrated liquid waste returns to DSTs. Secondary outputs from the process are evaporator condensate and trace air emissions. From the material balance calculations in Appendix A, it is estimated that the waste inventory in the incoming waste feed would be distributed among the output streams as follows: 


\begin{tabular}{lr} 
Stream & Percentage of Original Inventory \\
\hline DST Returns & $84.73 \%$ \\
Category 3 LLW & $15.10 \%$ \\
Evaporator Condensate & $5.7 \times 10-2$ of $1 \%$ \\
Category 1 LLW & $1.7 \times 10-3$ of $1 \%$ \\
Fugitive Air Emissions & $4.6 \times 10-6$ of $1 \%$
\end{tabular}

Additional information regarding waste forms and volumes is provided in the data tables following Section 4. 


\subsection{DESCRIPTION OF PROCESS FACILITY AND EQUIPMENT}

\subsection{FACILITY DESCRIPTION}

The principal intent of conceptualizing the NTF is to show that a processing capability could be devised for treating the most extremely contaminated debris that would be generated during the removal (i.e., excavation and demolition) of SSTs and related ancillary components to residual levels that would permit the solids to be disposed as LLMW.

The Solid Waste Treatment Facility (SWTF) described in TWRS Systems Engineering Study for the Closure of Single-Shell Tanks, Appendix J (Boomer et al 1991) was the basis for conceptualizing the building structure to house the processing equipment described in Section 4.2. The SWTF concept was for a facility that would operate continuously for a 10-year period supporting a single mission (closure of SST farms). Over that time, the SWTF would receive and process some $495,000 \mathrm{yd}^{3}$ of mixed solid waste, consisting of debris from demolition of SSTs, related ancillary equipment, and miscellaneous tanks, as well as large volumes of contaminated soil from tank farms. Processing objectives were to:

- Remove 90 percent of the radionuclides and hazardous constituents from the solids.

- Facilitate disposal of 90 percent of the incoming solids volume in a landfill.

- Dispose of 10 percent (or less) of the solids and 10 percent (or less) of the radionuclides and hazardous constituents as mixed waste.

The processing criteria for the current study are that (1) contamination levels in solids going to a landfill (i.e, ERDF) are to be within Category 1 LLW limits, (2) contamination levels in solids going to LLBG are to be within Category $3 \mathrm{LLW}$ limits, and (3) the separated radionuclides and hazardous constituents are to be segregated as a concentrated solution that can be returned to DSTs for eventual treatment (vitrification) by the TWRS PC.

Significant differences in waste processing requirements between the NTF and SWTF are as follows:

- For the SWTF concept, it was assumed that the waste feed would include large volumes of contaminated soil. The present study does not apply this assumption. It is anticipated that little (possibly none) of the soil excavated at tank farms would exhibit levels of contamination exceeding the Category 3 LLW disposal limits. Therefore, hypothetically at least, disposal options exist for soil that would not obligate DOE to process (treat) it first.

- For this study, the quantity of heavily contaminated debris that is envisioned to be generated in the course of clean closure of the AX Tank Farm (see Section 2.0) is significantly less (by approximately 50 percent) than the pro rata fraction of the quantity identified in conceptualizing the SWTF. To a large extent, this difference is traceable to the divergent assumptions regarding the amount of contaminated soil in the waste feed. 
- With a longer operating period and lower waste feed volume and delivery rate compared to previous assumptions, the scale of the operation required to process the waste is reduceable to some degree. For purposes of this study, the structure concept has been retained from the previous study, though some aspects have been modified to reflect the current waste feed input information, criteria, interfaces, and mission.

It is envisioned that the NTF, operating over a longer time frame, would support a variety of projects (including SST farm closure projects and other unrelated Hanford cleanup projects) in a series of separate operations (campaigns). Between campaigns, the processing area within the facility would undergo decontamination, equipment that is nonessential to the next campaign would be decontaminated and removed, new components would be brought in, and the process train for the next campaign would be assembled. The processing area would be physically isolated from manned access areas by continuous shielding walls, seals, and separate ventilation, and would have no permanent internal walls or partitions. This arrangement provides flexibility and would make the maximum amount of space available to arrange equipment over a succession of campaigns.

As illustrated in Figure 4.1, the NTF would be housed in a single-story reinforced concrete building, with plan (outline) dimensions of approximately $268 \mathrm{ft}$. by $520 \mathrm{ft}$, and a height of 108 $\mathrm{ft}$. The building would occupy a site of approximately $10 \mathrm{acres}$, with allowances for parking, setback, and vehicle access. The NTF structure has the same plan outline and dimensions as the SWTF. Below-grade utility chases and galleries in the earlier concept were eliminated. All fixed utilities and systems identifed in the earlier facility concept were retained. These systems include:

- Raw water and firewater supply

- Fire protection and detection

- Heating, ventilation, and air conditioning systems

- Normal electrical distribution

- Standby electrical distribution

- Uninterruptible power source

- Process equipment decontamination and repair

- Compressed air and gas distribution

- Process air

- Distributed control system

- Communications

- Analytical facilities

- Health physics (radiological) monitoring equipment

The labor and materials involved to construct the building and equip these systems were revised from the original estimate to consider the reduced extent and complexity of the structure. The capital cost estimate for the NTF is included as Appendix B of this report. 
Figure 4-1. New Treatment Facility

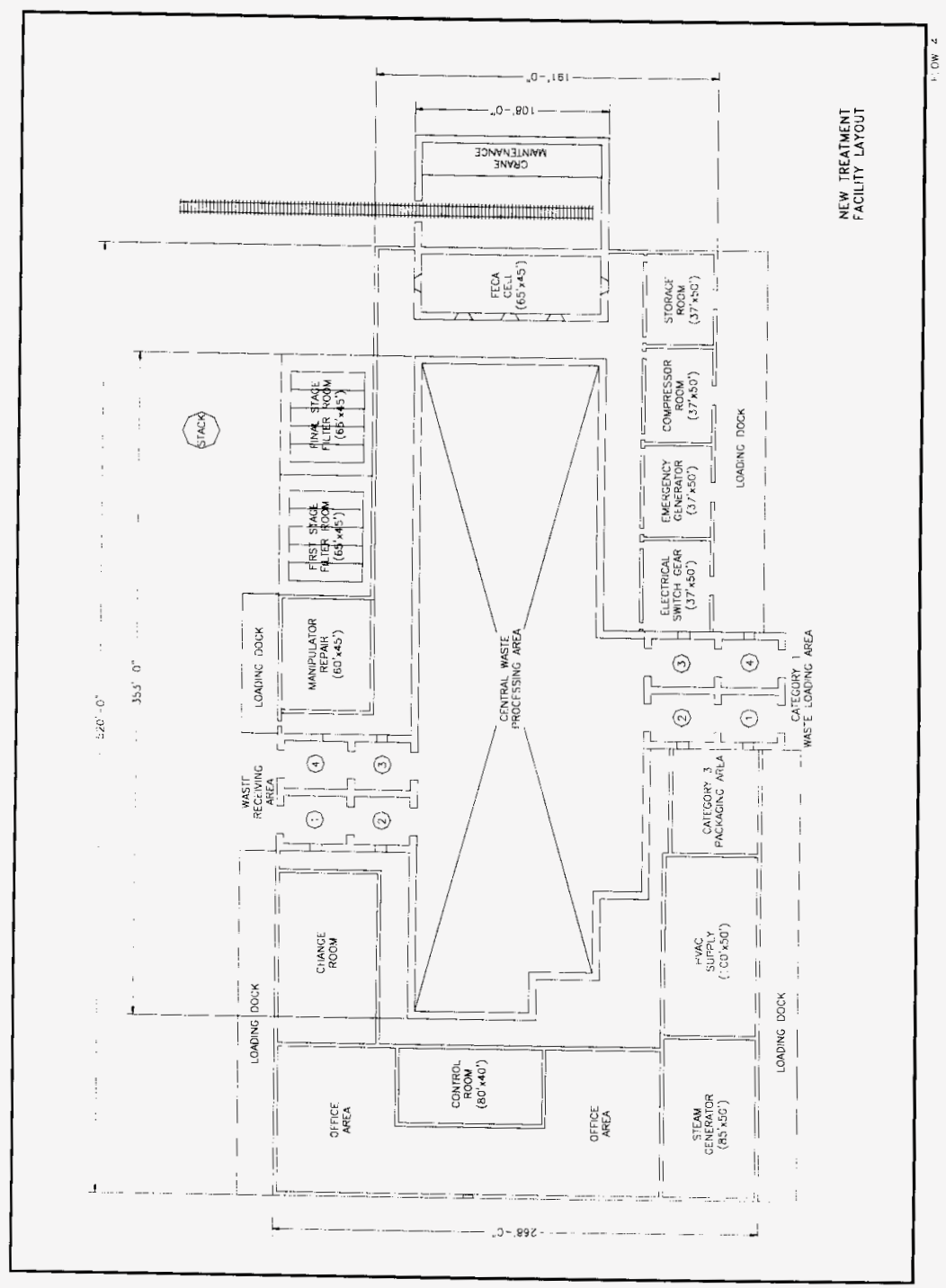




\subsection{PROCESS EQUIPMENT}

An overview of the proposed process logic is presented in Section 3.0. This section provides supplemental information regarding the numbers, types, and size ratings of the essential equipment components that would be used to process debris from the AX Tank Farm remediation project. It is envisioned that most process equipment will be constructed in a modular arrangement with piping and electrical jumper connections. Solids will be moved from point to point within the processing area by conveyor segments. Modules will be brought in and set up with the aid of the process area bridge crane. Modules will be designed with lifting points (eyes, bales) incorporated into the frames for this purpose. The lifting capacity of the crane (currently identified in the estimate as 30 tons) will limit the combined weight of components that can be arranged together as a "module." At the end of a campaign or mission, modules that are no longer needed will be removed from service. The process area crane will be used to disconnect jumpers between adjoining modules. Individual modules will then be picked up and moved to a separate work area, where they can be decontaminated, renovated, and/or disassembled.

For purposes of schedule estimation, it has been assumed that NTF construction would be coordinated with the AX Tank Farm remediation project, and that the project would be the initial user. The expected average processing rate is 25 container loads per day, equivalent to $67 \mathrm{~m} 3$ or $2,360 \mathrm{ft}^{3}$ of material per day. However, process equipment has been sized with capacity ratings that would support receiving and processing material at twice the average rate (i.e., at a maximum rate of 50 shielded boxes per 24 -hr operating day, the same rate at which containers will be loaded at the $\mathrm{AX}$ tank demolition site).

Shielded transport boxes - The rubble produced from demolition of the base slabs of the four $\mathrm{AX}$ tanks is expected to exhibit specific activity levels of ${ }^{137} \mathrm{Cs}$ in the range of 0.2 to $0.5 \mathrm{Ci} / \mathrm{ft}^{3}$ (COGEMA 1998). Based on the shielding analysis in Appendix $A$ of that report, it was concluded that no existing waste package design would be suitable for transporting debris with these levels of gamma emissions (WHC 1995), (i.e., existing designs would not be capable of limiting exposures to $10 \mathrm{mR} / \mathrm{hr}$ at $1 \mathrm{~m}$ as required). A new container design would be needed for on-site transportation of base slab debris. The shielding calculations indicated that a package with an aspect ratio of $1.0: 1.2: 4.0$ and a length of $11.5 \mathrm{ft}$. would have a tare weight of approximately $26,000 \mathrm{lbs}$, a cargo capacity of approximately $3.5 \mathrm{yd}^{3}$, and would require $4 \mathrm{in}$. of steel on the top and sides to provide appropriate shielding. This container was sized to be transportable by 20-ton container trucks similar to those currently used in the Hanford Environmental Restoration Program to haul RORO containers to/from ERDF.

For costing purposes, it was assumed that the boxes will be "owned" by the NTF (i.e., the capital cost to provide an appropriate number of boxes to support the AX Tank Farm remediation project is included in the NTF capital cost estimate). It has been estimated(COGEMA 1998) that the tank demolition operation will load approximately 50 shielded boxes per day ( 250 per week). The NTF will be capable of unloading and processing debris at an average rate of approximately 25 boxes per day (175 per week). Considering processing rates, schedule durations, day-use quantities and in-plant storage, it is anticipated that a minimum of 250 shielded boxes will be needed to support the AX Tank Farm remediation project. 
Waste delivery area - The waste delivery area will be arranged in a four-compartment configuration. The concept for the waste receiving operation is as follows. A container truck will back into the first compartment, off-load the shielded box onto a chain conveyor, and drive out. The outside access door will be closed off and sealed. Another door, between the first compartment and the second, will be unsealed and opened. The shielded box will be transferred by chain conveyor into the second compartment. The second door will be secured and sealed. A third door, between the second compartment and the dump area where the receiving hopper is located, will be opened. The shielded box will be opened and lifted by a hydraulic dumping mechanism, emptying the contents into the receiving hopper. The dumping mechanism will then lower and close the empty box. The access door to the dump area will be closed and sealed. Another door, between the second compartment and the third, will be unsealed and opened, and the empty box will be transferred by chain conveyor into the third compartment. The door opening into the third compartment will then be resecured. Inside the third compartment, the box will move through an external decontamination- and-release process consisting of (a) a wash station (similar to a car wash) and (b) a radiation survey station (similar to a whole-body counter). A fifth door, between the third and fourth compartments will be opened, and the decontaminated box will be repositioned. The door between the third and fourth compartments will be resecured. An external access door to the fourth compartment will be opened, enabling a container truck to back in, pick up the empty container, and drive away.

Dump mechanism for shielded boxes in second compartment - This mechanism will be situated in the second compartment of the waste receiving area and will be designed to perform the following functions. After the chain conveyor delivers and positions the box inside the compartment, the dump mechanism will:

- Remove (or open) the lid of the box (depending on specifics of the design of the box)

- Engage claspers to the box

- Raise the box for dumping. The mechanism rotates in the vertical plane about a forward pivot point. Prime movers are two long-throw hydraulic cylinders similar to cylinders used on end-dump semi-trailers. The box must be rotated through an angle somewhat greater than 90 degrees.

- Lower the box after dumping. The box is returned to its original position, the claspers are disengaged, and it is reclosed before it goes to "decon."

Decontamination and radiation survey equipment in third compartment - This equipment will be identical to the decontamination and survey equipment described for performing equivalent functions at the AX Tank Farm Enclosure Structure (COGEMA 1998).

Receiving hopper - The receiving hopper will be approximately $100 \mathrm{ft}$. long, $15 \mathrm{ft}$. wide at the top, and $15 \mathrm{ft}$. deep, with inward tapered sides (trapezoidal section). The hopper will be elevated on supports to provide the head room required to feed the autogenous grinding mill. The hopper will be fitted with a wear-resistant liner and a spray ring around the top to control dust, wash out residual fines, and facilitate decontamination of the hopper at the end of each facility operating campaign. The floor of the hopper will be sloped toward the mill. The hopper will be equipped with a scraper mechanism (e.g., a slusher) that will be used to reposition material toward the feed 
(discharge) end. A vibratory pan feeder will be provided at the discharge end of the hopper to control the rate of transfer of waste feed from the hopper to the autogenous mill. The hopper will provide an in-plant storage capacity equivalent to approximately 190 shielded boxes.

Metal shredder - The shredder will receive metal waste (Ancillary Metal - Stream 102; Tank Metal - Stream 105) and reduce it to $1 / 2$-in. shards. The shredder will have a throughput capacity of 4 tons/hr and capability to shear 1 -in. plate.

Small bridge crane - The portion of the process area, including the receiving hopper, the autogenous mill and the shredder, will be supported by a dedicated bridge crane. The bridge span will be $30 \mathrm{ft}$; the crane rails will be approximately $180 \mathrm{ft}$. long. The crane will be a nuclear service-rated crane with dual trolleys. One trolley will support a five-ton electromagnet that will be used to separate magnetic ferrous metal scrap from other waste feed and divert this material around the autogenous mill to the shredder. The second trolley will be equipped with a 10 -ton grapple that will be used to separate non- magnetic metal scrap (e.g, stainless steel pipe) from the feed and transfer it to the shredder.

Large bridge crane - Activities within the entire central section of the building can be supported by the large bridge crane. This also will be a nuclear service-rated crane, with dual trolleys (30ton and 5-ton hooks), a $100-\mathrm{ft}$. bridge and 500-ft. long rails. It is envisioned that the large crane would be used principally to set up the process train for a new campaign and to remove and replace components after a campaign has been concluded. The large and small bridge cranes will be installed as part of the NTF building construction. However, In the capital cost estimate (Appendix B), they are listed with process equipment items.

Acid washing and rinsing station - This equipment will consist of two stainless steel tanks, each approximately $1 \mathrm{~m}$ deep, $1.5 \mathrm{~m}$ wide, and $5 \mathrm{~m}$ long, with a $200-\mathrm{gal} / \mathrm{min}$ recirculation pump and an $85-\mathrm{gal} / \mathrm{min}$ transfer pump.

Autogenous mill - The mill will be a fully autogenous grinding mill, approximately $12 \mathrm{ft}$. in diameter by $10 \mathrm{ft}$. long, rated at 10 tons/hr, with a 375 -HP drive motor. The mill will be supplied with motor and couplings, rubber liner, and feed and discharge chutes. This equipment is heavy enough (approximately $440,000 \mathrm{lb}$ ) to require a fixed foundation pad, unlike most other components, which can be skid-mounted. A rubber liner and slow rotation speed (as opposed to a steel liner and fast rotation) will maximize abrasion (grinding) of the coarse solids and minimize fracturing. Because of the potential for generating contaminated airborne particulates during the operation, the air space inside the mill will be ventilated separately. Exhaust air from the mill will be ducted away to a HEPA filter unit.

Dryer - The dryer will receive washed metal (Stream 113) and coarse solids from the autogenous grinding step (Stream 123). The dryer will be an insulated sheet-metal enclosure, measuring 56 $\mathrm{ft}$. long, $12 \mathrm{ft}$. high, and $6 \mathrm{ft}$. wide. Radiant heating elements inside the dryer will be rated at 2 million Btu/hr. Washed solids will move through the enclosure on a conveyor belt. Belt speed and air flow through the dryer will be regulated to optimize the elimination of water vapor, heat retention, and drying time.

Acid digester - The underflow from the grinding mill (Stream 126) will be directed to the acid digester. The digester also receives acid wash solution (Stream 115) from the metal washing 
operation. Additional acid will be fed to the digester at a rate of $15 \mathrm{gal} / \mathrm{min}$. The digester will be a stainless steel leach tower with an interior auger lift. The tower will be approximately $5 \mathrm{ft}$. in diameter by $12 \mathrm{ft}$. high. Throughput capacity will be rated at 6 tons $/ \mathrm{hr}$ of solids.

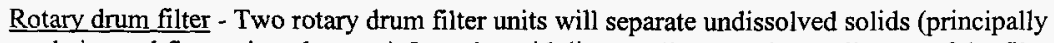
sand-size and finer mineral matter) from the acid digester (Stream 132). All parts of the filter unit contacting liquid feed would be constructed of stainless steel. The two units will have the capacity to produce a combined 6 tons $/ \mathrm{hr}$ of solids cake and pass $20 \mathrm{gal} / \mathrm{min}$ of filtered liquid.

Centrifuge - The centrifuge will receive the overflow from the acid digester (Stream 131) and the filtered liquid from the rotary drum filters (Stream 133) and will separate out residual solids. The centrifuge will have a feed rating of $50 \mathrm{gal} / \mathrm{min}$. Filtered liquid from the centrifuge (Stream 134) will be routed to the evaporator for concentration.

Evaporator - Two evaporator units will remove a combined 3,500 gal/hr of water from an incoming solution (Stream 134) containing an estimated $20 \mathrm{wt}$ percent dissolved solids. A portion of the evaporator condensates will be reused in the process. The balance will be routed to the 200-Area ETF.

Category 1 waste loading station - This portion of the facility is conceptualized as a fourcompartment area (similar to the waste receiving area) for delivering and picking up 20-ton RO/RO containers. In the first compartment, the container truck backs in and off- loads an empty RO/RO container onto a chain conveyor. The conveyor then repositions the RO/RO trailer from the first compartment to the second. Access doors to the second compartment are then closed and sealed off. The container is opened. Washed and dried solid waste debris (i.e, material in Stream 124) is transferred into the container from a bulk storage hopper by a vibratory pan feeder. The door between compartments two and three is opened, and the loaded container is transferred into the third compartment. Within this compartment, the container is subjected to the same type of external decontamination-and-release process described above for empty shielded boxes. The released RO/RO container is then transferred to the fourth compartment, where a container truck backs in and picks it up.

Category 1 waste storage hopper - The storage hopper will be approximately $50 \mathrm{ft}$. long, $20 \mathrm{ft}$. wide at the top, and $20 \mathrm{ft}$. deep, with tapered sides (trapezoidal section). The hopper will be elevated on supports to gain the head room required to load 20 -ton RO/RO containers. The hopper will be fitted with a wear-resistant liner and a spray ring around the top to control dust, wash out residual fines, and aid in decontamination after each facility operating campaign. The floor of the hopper will be sloped toward a discharge chute to the vibratory pan feeder. The pan feeder will be employed to control the transfer of material from the hopper into the trailers. During the loading process, the chain conveyor segment within the second compartment will reposition the RO/RO container so that it is evenly loaded along its length.

Category 3 waste solidification/loading station - The solidification station will receive filter cake (solids with residual moisture content) from Streams 135 and 136. The solids will first be neutralized by caustic addition and then entrained as fine aggregate in Portland cement paste. The mixture will be poured into 55-gal drums for disposal. The mixing and metering equipment will be sized to produce approximately $4 \mathrm{yd}^{3}$ of material per hour. Drummed Category 3 waste will be transported by truck to LLBG for disposal. 
Aqueous make-up (reagent storage) tanks - These tanks include two 50,000-gal tanks for bulk acid and caustic storage, two 10,000-gal mixing tanks, and related pumps and controls.

Staging tanks for DST returns - Two 100,000-gal stainless steel tanks will receive and temporarily store the concentrated liquid waste solution from the process (Stream 152) for transfer to DSTs. The tanks will be $15 \mathrm{ft}$. in diameter and $72 \mathrm{ft}$. long. They will be placed in a concrete vault adjacent to the NTF structure, measuring $40 \mathrm{ft}$. by $80 \mathrm{ft}$. (plan) by $20 \mathrm{ft}$. deep. The vault will be constructed below grade with 2 -ft. thick walls and cover blocks. While the liquid waste is held in these tanks, caustic additions will be made to meet specifications for transfer to the DSTs. The tanks will be equipped with separate mixing and transfer pumps.

\subsection{DATA TABLES}

Data tables have been assembled to summarize the resources, staffing, equipment, waste quantities, and emissions that would be needed to construct and operate the proposed NTF in support of clean closure of the AX Tank Farm. Additionally, this section includes summary information on project costs and schedule. 
Table 4-1. Waste Form and Volume Projections

\begin{tabular}{|c|c|}
\hline Waste Form & Characteristic \\
\hline \multicolumn{2}{|l|}{ Category $1 \mathrm{LLW}$ : } \\
\hline Quantity & 6,360 tons \\
\hline Number of containers & $318 \mathrm{RO} / \mathrm{RO}$ container loads \\
\hline Container size & $20^{\prime} \mathrm{L} \times 7.5^{\prime} \mathrm{W} \times 5.5^{\circ} \mathrm{H}$ \\
\hline Radionuclide Inventory & $\begin{array}{l}\text { Approx. } 22.3 \mathrm{Ci}^{90} \mathrm{Sr}, 1.08 \mathrm{Ci}^{137} \mathrm{Cs}, 0.025 \\
\text { Ci TRU }\end{array}$ \\
\hline Disposal location & Environmental Restoration Disposal Facility \\
\hline \multicolumn{2}{|l|}{ Category $3 \mathrm{LLW}$ : } \\
\hline Quantity & $70,000 \mathrm{ft}^{3}$ \\
\hline Number of containers & $\begin{array}{l}\text { 9,520 (perfect filling); } 10,578(90 \% \\
\text { fill factor) }\end{array}$ \\
\hline Container size & 55-gal drums \\
\hline Radionuclide Inventory & $\begin{array}{l}\text { Approx. } 196,000 \mathrm{Ci}^{90} \mathrm{Sr}, 9,750 \mathrm{Ci}^{137} \mathrm{Cs} \text {, } \\
192 \mathrm{Ci} \text { TRU }\end{array}$ \\
\hline Disposal location & Low-Level Burial Grounds \\
\hline \multicolumn{2}{|c|}{ Concentrated Liquid Waste (DST Returns): } \\
\hline Quantity & Approx. $1,053,000 \mathrm{gal}$ \\
\hline Number of containers & none (bulk transfers) \\
\hline Container size & N/A \\
\hline Radionuclide Inventory & $\begin{array}{l}\text { Approx. } 1.10 \times 10^{6} \mathrm{Ci}{ }^{90} \mathrm{Sr}, 5.47 \times 10^{4} \mathrm{Ci} \\
{ }^{13} \mathrm{Cs}, 1,075 \mathrm{Ci} \text { TRU }\end{array}$ \\
\hline Disposal location & $\begin{array}{l}\text { Transfer to DSTs for eventual vitrification } \\
\text { with other tank waste }\end{array}$ \\
\hline \multicolumn{2}{|l|}{ Evaporator Condensate } \\
\hline Quantity & Approx. $1,200,000$ gal \\
\hline Number of containers & none (bulk transfers) \\
\hline Container size & N/A \\
\hline Radionuclide Inventory & $\begin{array}{l}\text { Approx. } 734 \mathrm{Ci}{ }^{90} \mathrm{Sr}, 35 \mathrm{Ci}{ }^{137} \mathrm{Cs}, \\
0.72 \mathrm{Ci} \text { TRU }\end{array}$ \\
\hline Disposal location & 200-East Effluent Treatment Facility \\
\hline
\end{tabular}


Table 4-2. Construction Resource Requirements

\begin{tabular}{|l|l|}
\hline \multicolumn{1}{|c|}{ Construction Resource } & \multicolumn{1}{c|}{ Quantity } \\
\hline Land Area & $\begin{array}{l}\text { Site will be approx. 10 acres with parking and } \\
\text { setback. Building footprint will cover } \\
\text { approx. 3.2 acres. }\end{array}$ \\
Temporary Laydown Area for Building & None (adequate area for laydown on site) \\
Construction & \\
\hline Concrete & $83,150 \mathrm{yd}^{3}$ \\
Water (6.6 wt \%) & $2,475,000 \mathrm{gal}$ \\
Cement $(14.6 \mathrm{wt} \%)$ & $45,884,000 \mathrm{lb}$. \\
Sand (34.1 wt \%) & $107,063,000 \mathrm{lb}$. \\
Gravel (44.8 wt \%) & $140,712,000 \mathrm{lb}$. \\
Rebar (10 lb/ft $\left.{ }^{3}\right)$ & $22,451,000 \mathrm{lb}$. \\
\hline Steel & None (see rebar above) \\
& \\
\hline Excavation & \\
Site Grading (cut and fill) & \\
For Foundations & Approx. $24,200 \mathrm{yd}^{3}$ \\
\hline
\end{tabular}


HNF-4098, Rev. 0

Table 4-3. Radiological Air Emissions (in curies)

\begin{tabular}{|c|c|c|c|}
\hline $\begin{array}{c}\text { Analyte } \\
\text { (Ci) }\end{array}$ & $\begin{array}{c}\text { Grinding } \\
\text { Particulates (1) } \\
\text { (Ci) }\end{array}$ & $\begin{array}{l}\text { Dryer } \\
\text { Offgas (2) } \\
\text { (Ci) }\end{array}$ & $\begin{array}{c}\text { Totals } \\
\text { (Ci) }\end{array}$ \\
\hline $3 \mathrm{H}$ & $1.100 \mathrm{e}-07$ & $6.529 \mathrm{e}-08$ & $1.753 \mathrm{e}-07$ \\
\hline $14 \mathrm{C}$ & $1.269 \mathrm{e}-08$ & $7.492 \mathrm{e}-09$ & $2.018 \mathrm{e}-08$ \\
\hline $59 \mathrm{Ni}$ & $2.745 \mathrm{e}-07$ & $1.634 e-07$ & $4.379 \mathrm{e}-07$ \\
\hline $60 \mathrm{Co}$ & $3.738 \mathrm{e}-06$ & $2.245 \mathrm{e}-06$ & $5.984 \mathrm{e}-06$ \\
\hline $63 \mathrm{Ni}$ & $2.721 \mathrm{e}-05$ & $1.613 \mathrm{e}-05$ & $4.334 \mathrm{e}-05$ \\
\hline $79 \mathrm{Se}$ & $2.278 \mathrm{e}-07$ & $1.349 \mathrm{e}-07$ & $3.627 \mathrm{e}-07$ \\
\hline $90 \mathrm{Sr}$ & $3.693 \mathrm{e}-02$ & $2.237 \mathrm{e}-02$ & $5.930 \mathrm{e}-02$ \\
\hline $90 \mathrm{Y}$ & $3.693 \mathrm{e}-02$ & $2.237 \mathrm{e}-02$ & $5.930 \mathrm{e}-02$ \\
\hline $93 \mathrm{mNb}$ & $7.798 \mathrm{e}-07$ & $4.497 \mathrm{e}-07$ & $1.229 \mathrm{e}-06$ \\
\hline $932 r$ & $1.005 \mathrm{e}-06$ & $5.966 \mathrm{e}-07$ & $1.602 \mathrm{e}-06$ \\
\hline $99 \mathrm{Tc}$ & $8.785 \mathrm{e}-08$ & $5.176 \mathrm{e}-08$ & $1.396 \mathrm{e}-07$ \\
\hline 106Ru & $7.933 \mathrm{e}-09$ & $4.497 \mathrm{e}-07$ & $1.229 \mathrm{e}-06$ \\
\hline $113 \mathrm{mCd}$ & $3.498 \mathrm{e}-06$ & $2.114 \mathrm{e}-06$ & $5.612 \mathrm{e}-06$ \\
\hline $125 \mathrm{Sb}$ & $1.556 \mathrm{e}-06$ & $9.327 \mathrm{e}-07$ & $2.489 \mathrm{e}-06$ \\
\hline $126 \mathrm{Sn}$ & $3.617 \mathrm{e}-07$ & $2.139 \mathrm{e}-07$ & $5.756 \mathrm{e}-07$ \\
\hline $129 I$ & $1.703 \mathrm{e}-10$ & $1.003 \mathrm{e}-10$ & $2.707 \mathrm{e}-10$ \\
\hline $134 \mathrm{Cs}$ & $7.896 \mathrm{e}-09$ & $4.403 \mathrm{e}-09$ & $1.230 \mathrm{e}-08$ \\
\hline $135 \mathrm{Cs}$ & $0.000 \mathrm{e}+00$ & $0.000 \mathrm{e}+00$ & $0.000 \mathrm{e}+00$ \\
\hline $137 \mathrm{Cs}$ & $9.451 \mathrm{e}-04$ & $5.617 \mathrm{e}-04$ & $1.507 \mathrm{e}-03$ \\
\hline $137 \mathrm{mBa}$ & $8.940 \mathrm{e}-04$ & $5.311 \mathrm{e}-04$ & $1.425 \mathrm{e}-03$ \\
\hline $151 \mathrm{Sm}$ & $8.012 \mathrm{e}-04$ & $4.685 \mathrm{e}-04$ & $1.270 \mathrm{e}-03$ \\
\hline $152 \mathrm{Eu}$ & $4.165 e-07$ & $2.610 \mathrm{e}-07$ & $6.775 \mathrm{e}-07$ \\
\hline $154 \mathrm{Eu}$ & $4.811 \mathrm{e}-05$ & $2.951 \mathrm{e}-05$ & $7.762 \mathrm{e}-05$ \\
\hline $155 \mathrm{Eu}$ & $3.529 \mathrm{e}-05$ & $2.114 \mathrm{e}-05$ & $5.643 \mathrm{e}-05$ \\
\hline $226 \mathrm{Ra}$ & $1.962 \mathrm{e}-11$ & $1.139 \mathrm{e}-11$ & $3.101 \mathrm{e}-11$ \\
\hline $227 \mathrm{Ac}$ & $1.012 \mathrm{e}-10$ & $5.757 \mathrm{e}-11$ & $1.587 \mathrm{e}-10$ \\
\hline $228 \mathrm{Ra}$ & $8.542 \mathrm{e}-14$ & $5.799 \mathrm{e}-13$ & $6.654 \mathrm{c}-13$ \\
\hline $229 \mathrm{Th}$ & $3.32 \mathrm{Je}-14$ & $6.948 \mathrm{e}-14$ & $1.027 \mathrm{e}-13$ \\
\hline $231 \mathrm{~Pa}$ & $1.510 \mathrm{e}-10$ & $8.542 \mathrm{e}-11$ & $2.364 \mathrm{e}-10$ \\
\hline 232Th & $4.701 \mathrm{e}-16$ & $3.164 \mathrm{e}-15$ & $3.634 \mathrm{e}-15$ \\
\hline $232 \mathrm{U}$ & $3.031 \mathrm{e}-12$ & $2.055 \mathrm{e}-11$ & $2.357 \mathrm{e}-11$ \\
\hline $233 \mathrm{U}$ & $1.24 \mathrm{ie}-11$ & $8.440 \mathrm{e}-11$ & $9.681 \mathrm{e}-11$ \\
\hline $234 \mathrm{U}$ & $1.109 \mathrm{e}-10$ & $2.075 \mathrm{c}-10$ & $3.183 \mathrm{e}-10$ \\
\hline $235 \mathrm{U}$ & $4.507 \mathrm{e}-12$ & $8.396 \mathrm{e}-12$ & $1.290 \mathrm{e}-11$ \\
\hline $236 \mathrm{U}$ & $4.717 \mathrm{e}-12$ & $9.174 \mathrm{e}-12$ & $1.389 \mathrm{e}-11$ \\
\hline $237 \mathrm{~Np}$ & $3.221 \mathrm{e}-10$ & $2.000 \mathrm{e}-10$ & $5.220 \mathrm{e}-10$ \\
\hline $238 \mathrm{Pu}$ & $9.285 \mathrm{e}-07$ & $6.088 \mathrm{e}-07$ & $1.537 \mathrm{e}-06$ \\
\hline $238 \mathrm{U}$ & $1.003 \mathrm{e}-10$ & $1.852 \mathrm{e}-10$ & $2.856 \mathrm{c}+10$ \\
\hline $239 \mathrm{Pu}$ & $1.031 \mathrm{e}-05$ & $6.474 \mathrm{e}-06$ & $1.679 \mathrm{e}-05$ \\
\hline $240 \mathrm{Pu}$ & $2.990 \mathrm{e}-06$ & $3.251 \mathrm{e}-06$ & $6.240 \mathrm{e}-06$ \\
\hline $239 / 240 \mathrm{Pu}$ & $1.988 e-05$ & $1.368 \mathrm{e}-05$ & $3.356 \mathrm{e}-05$ \\
\hline $241 \mathrm{Am}$ & $2.150 \mathrm{e}-05$ & $1.386 \mathrm{e}-05$ & $3.537 \mathrm{e}-05$ \\
\hline $241 \mathrm{Pu}$ & $6.435 e-05$ & $4.111 \mathrm{e}-05$ & $1.055 \mathrm{e}-04$ \\
\hline
\end{tabular}


HNF-4098, Rev. 0

\begin{tabular}{|c|c|c|c|}
\hline $\begin{array}{c}\text { Analyte } \\
(\mathbf{C i})\end{array}$ & $\begin{array}{c}\text { Grinding } \\
\text { Particulates (1) } \\
(\mathbf{C i})\end{array}$ & $\begin{array}{c}\text { Dryer } \\
\text { Offgas (2) } \\
(\mathbf{C i})\end{array}$ & $\begin{array}{c}\text { Totals } \\
(\mathbf{C i})\end{array}$ \\
\hline $242 \mathrm{Cm}$ & $2.655 \mathrm{e}-08$ & $1.53 \mathrm{le}-08$ & $4.186 \mathrm{e}-08$ \\
\hline $242 \mathrm{mAm}$ & $0.000 \mathrm{e}+00$ & $0.000 \mathrm{e}+00$ & $0.000 \mathrm{e}+00$ \\
\hline $242 \mathrm{Pu}$ & $4.480 \mathrm{e}-10$ & $2.967 \mathrm{e}-10$ & $7.446 \mathrm{e}-10$ \\
\hline $243 \mathrm{Am}$ & $2.077 \mathrm{e}-09$ & $4.373 \mathrm{e}-09$ & $3.450 \mathrm{e}-09$ \\
\hline $243 \mathrm{Cm}$ & $3.082 \mathrm{e}-09$ & $2.026 \mathrm{e}-09$ & $5.108 \mathrm{e}-09$ \\
\hline $244 \mathrm{Cm}$ & $1.224 \mathrm{e}-07$ & $8.023 \mathrm{e}-08$ & $2.026 \mathrm{e}-07$ \\
\hline
\end{tabular}

Decay Date: $1 2 / 3 \longdiv { 1 / 9 9 }$

Note 1: To estimate grinding particulate emissions, it was assumed that a decontamination factor of 10,000 for the grinding step would be present, and that exhaust air would be routed through a HEPA filter with an efficiency of 3,333 .

Note 2: To estimate dryer offgas emissions, it was assumed that 0.001 of the combined radiological inventory in Streams 113 and 123 going through the dryer would become carryover, and that the offgas stream is unfiltered. 
Table 4-4. Manning List for the Proposed New Treatment Facility

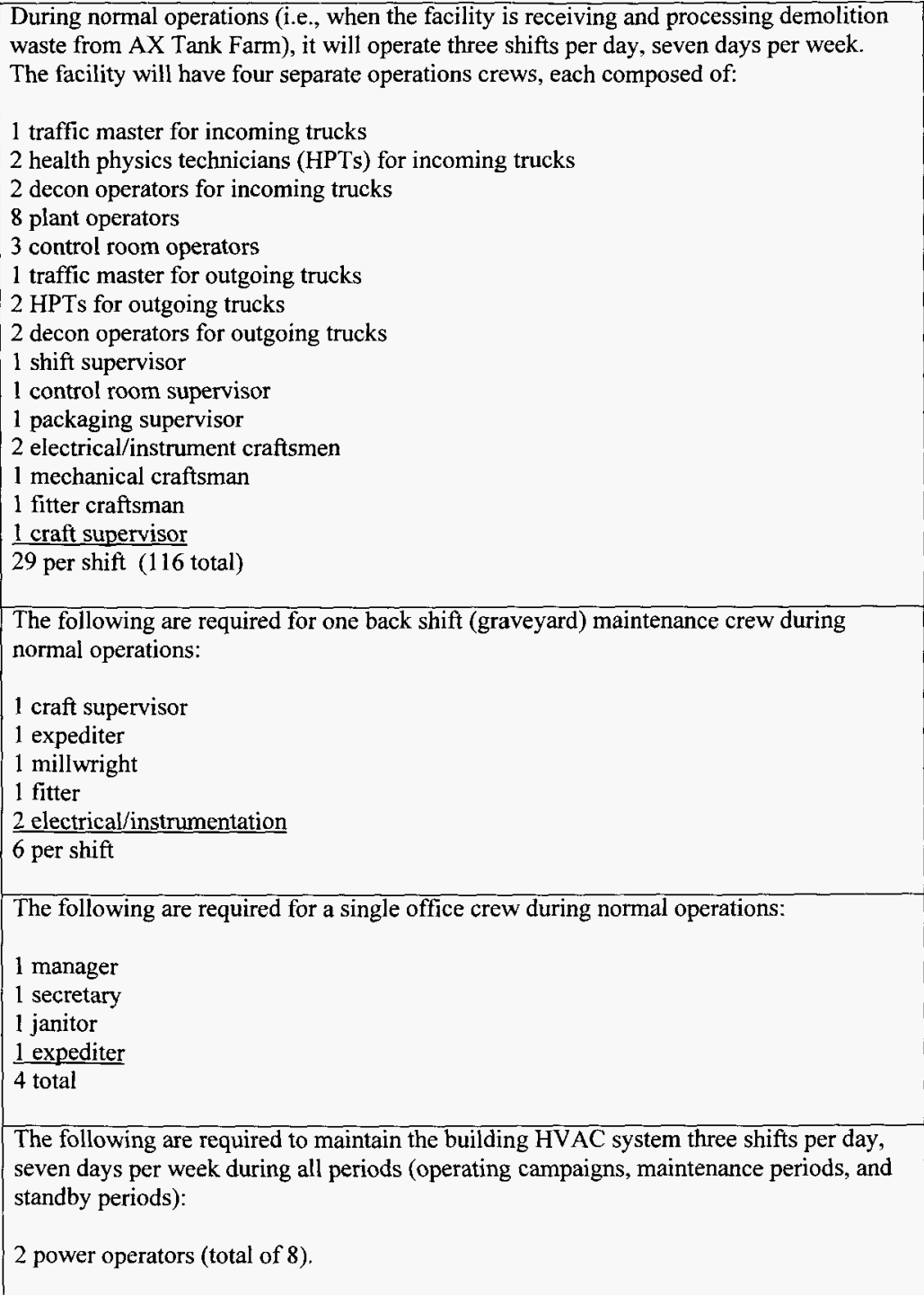


It is anticipated that building maintenance can be conducted by the operations maintenance personnel between operating campaigns.

The grand total is $29+29+29+29+6+4+8=\underline{134}$ people

The following are required on a single day shift during maintenance and $\mathrm{D} / \mathrm{D}$ operations (scheduled two days for every day of operation):

4 HPTs for general maintenance support

4 decon operators for general maintenance support

4 control room and equipment operators

1 shift supervisor

1 control room supervisor

1 packaging supervisor

4 electrical/instrument craftsmen

2 mechanical/millwright craftsman

2 fitter craftsman

2 craft supervisor

25 total for maintenance

The following are required for a single office crew during maintenance periods and $\mathrm{D} / \mathrm{D}$ operations:

1 manager

1 secretary

1 janitor

2 expediter

5 total

The following are required to maintain the building HVAC system three shifts per day, seven days per week during all periods (operating campaigns, maintenance periods, and standby periods):

2 power operators (total of 8 ).

The grand total is $25+5+8=\underline{38 \text { people }}$

The following are required on a single day shift for stand-by periods:

1 HPT for general support

1 decon operator for general support

1 control room/equipment operator

1 manager

1 secretary

0.5 janitor

5.5 total 
The following are required to maintain the building HVAC system three shifts per day, seven days per week during all periods (operating campaigns, maintenance periods, and stand-by periods):

2 power operators (total of 8 ).

The grand total is $5.5+8=13.5$ people

Table 4-5. Cost Summary

\begin{tabular}{|l|c|}
\hline \multicolumn{1}{|c|}{ Cost Component } & Cost (Note 1) \\
\hline Post-Retrieval Monitoring and Maintenance & N/A \\
\hline Capital & \\
& \\
Engineering and Construction Management & $274,880,000$ \\
PPF Building Construction & $180,880,000$ \\
Process Equipment & $246,770,000$ \\
Project Management & $96,420,000$ \\
& Total $=798,950,000$ \\
& N/A \\
\hline Research and Development & $15,370,000$ \\
\hline Operating Labor and Materials & $6,740,000$ \\
Cat 1 and Cat 3 Waste Disposal & Total $=22,110,000$ \\
& N/A (Note 2) \\
\hline Decontamination and Decommissioning & \\
\hline
\end{tabular}

Note 1: Costs are rounded to the nearest $\$ 10,000$. Costs are stated in 1999 dollars and do not include escalation. Costs include contingencies averaging 42 percent for capital costs and 54 percent for operating costs.

Note 2: Study scope did not address facility decontamination and decommissioning. 


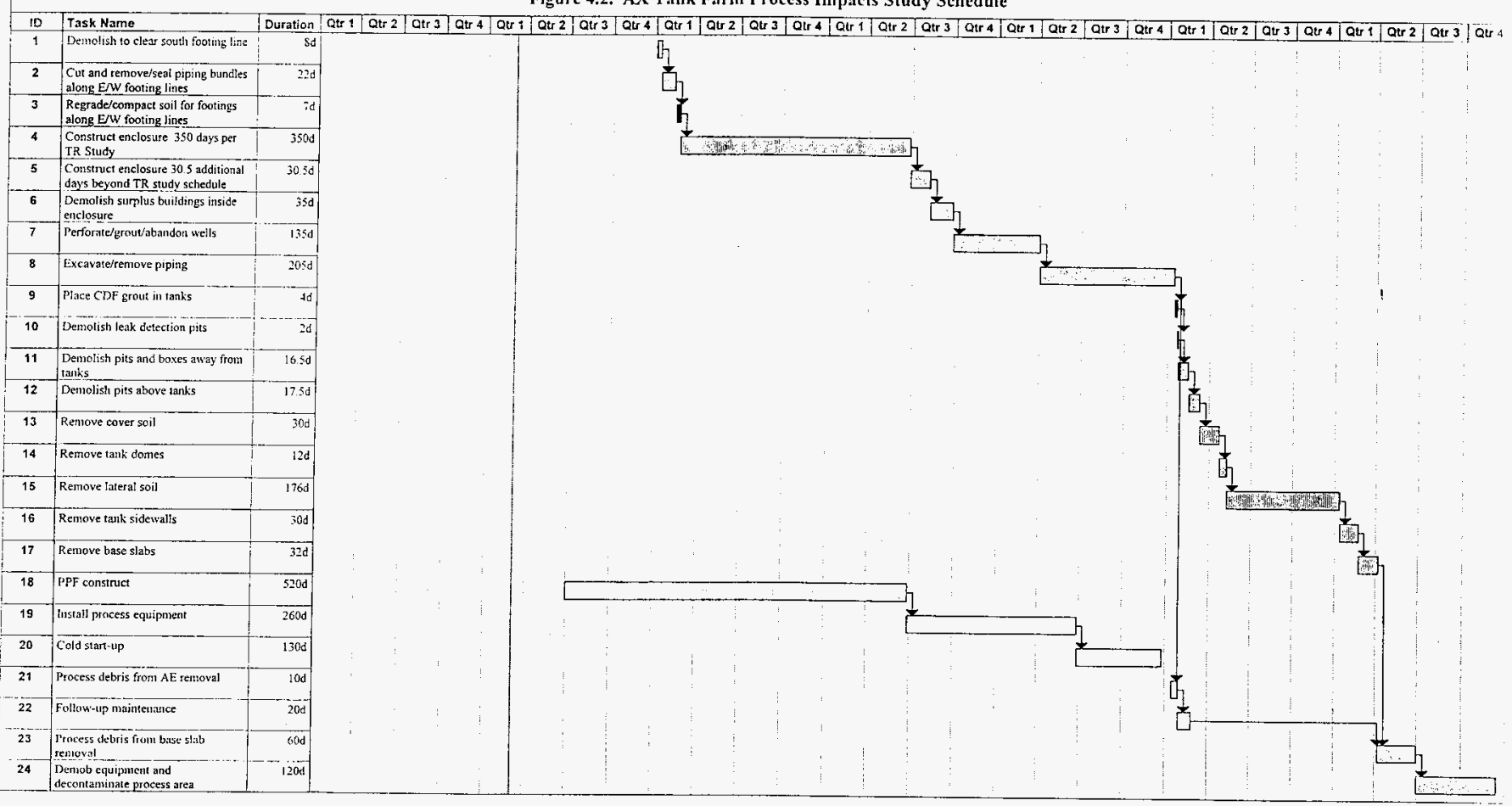


HNF-4098, Rev. 0

\subsection{IMPLEMENTABILITY ISSUES}

\section{S.1 DESIGN MATURITY}

The material balance for the proposed debris treatment process (see Appendix A) should be regarded as an initial best estimate of process performance. A number of assumptions have been applied to make these calculations regarding decontamination factors and mechanical efficiencies that cannot be independently verified or evaluated at this time. Consequently, assessments regarding the projected efficiency of the proposed process may be either overstated or understated. Continuous refinement of the material balance would be an integral aspect of process design/development should DOE elect to explore this concept in greater detail.

\subsection{UTILITY OF NTF PROCESS CONCEPT FOR TREATING LARGE VOLUMES OF CONTAMINATED SOIL}

In developing the process logic for this study, primary emphasis was placed on separating tank waste contaminants from metal and concrete substrates. The study does not address the problem of separating contaminants from granular soils in comparable detail. To the extent that contamination of soil is a surface phenomenon (i.e., contamination is sorbed onto the outside surfaces of soil particles), the NTF process should be a highly effective treatment method. However, data from soil washing treatability tests on Hanford Site soils indicate that some waste constituents are capable of interacting chemically with minerals in the soil (e.g., binding as interlayer cations in sheet silicate minerals), in which form they are difficult to extract by water washing and size separation. The NTF process logic incorporates water washing and size separation as well as mechanical abrasion and acid dissolution (strategies not typically involved in soil washing). It is anticipated that the NTF process would produce a significantly better decontamination factor for soil than has been demonstrated for conventional soil washing $(\mathrm{DF}=10)$. However, the NTF process decontamination factor for soil may not be large enough that it could be exploited successfully to reduce contamination in Category 3 soil to Category 1 levels. If significant quantities of Category 3 soil are generated as a consequence of closing tank farms (e.g., from excavation of soil containing leakage losses from tanks during waste retrieval operations), there may be a significant cost incentive (traceable to the large difference in disposal costs for Category $I$ and 3 soil) for optimizing the NTF process for enhanced soil decontamination.

\subsection{LARGE PRO.JECTED VOLUME OF CATEGORY 3 WASTE}

By comparing information presented elsewhere in this report regarding incoming waste feed volumes and outgoing waste disposal volumes, it may be observed that, for each $1 \mathrm{ft}^{3}$ of incoming waste from demolition of AX tanks and ancillary equipment, the NTF process would generate approximately $0.8 \mathrm{ft}^{3}$ of Category $1 \mathrm{LLW}, 0.5 \mathrm{ft}^{3}$ of Category $3 \mathrm{LLW}, 8$ gal of slightly contaminated evaporator condensate, and 7 gal of concentrated liquid waste (DST returns). Excluding the stream going to DSTs, Category 3 waste generation poses the greatest ongoing disposal cost burden from the NTF process. Clearly, this aspect of the process logic and material balance would be a focus for additional process refinement. 
HNF-4098, Rev. 0

\subsection{STORAGE SPACE IN DSTS}

According to the TWRS planning basis for DST operations, availability of storage space in DSTs will be an ongoing logistical issue during the Initial SST Retrieval Systems (ISSTRS) Program and beyond Phase 1 of the TWRS Privatization Program. The results of this study suggest that waste processing of heavily contaminated debris from clean closure of SST farms would result in production of large additional volumes of concentrated liquid waste that (per directed study assumption) would be transferred to DSTs. This study does not address the issue of how the additional liquid waste volumes from NTF operations would be accommodated in DST operations.

\subsection{ADDITIONAL LIFE-CYCLE COST CONSIDERATIONS}

This is the latest in a series of engineering studies that have been prepared to evaluate various aspects of clean and landfill closures of the AX Tank Farm. This study provides estimates of the capital and operating costs to construct the NTF and to process heavily contaminated debris from demolition of AX tanks and ancillary equipment. This waste stream is too heavily contaminated to be disposed without treatment. Additional LLW disposal costs have been identified and quantified in this study as a result of treatment of the heavily contaminated debris.

Waste processing and disposal costs for vitrified DST waste were not formally evaluated as part of the cost estimating for this study. However, COGEMA Engineering has prepared a separate estimate of the number of additional glass logs that could be generated as a result of processing heavily contaminated debris from the AX Tank Farm. For this estimate, it was assumed that the iron in the contaminant inventory in DST returns will be the limiting constituent with regard to waste loading in the glass form, and that the entire inventory would go into HLW glass production (i.e, no distribution of the inventory between HLW and LAW production was assumed). The COGEMA estimate indicates that approximately 202.7 metric tons (MT) of additional HLW glass (equivalent to 72 canisters) would be produced.

Estimated processing and disposal costs for the additional HLW glass are as follows:

- Cost to process: $\$ 338,000 / \mathrm{MT} \times 202.7 \mathrm{MT} \quad=\$ 68,513,000$

- Cost to dispose: $\$ 960,000 /$ container $\times 72$ containers $=\$ 69,120,000$

$$
\text { Total }=\$ 137,633,000
$$

Unit costs are based on a DOE "1996 Storage and Disposal Project Life Cycle Estimate," which includes all Hanford Site and repository storage and disposal costs plus contingency.

\subsection{SHIELDED CONTAINERS}

There is significant uncertainty regarding the number of special-purpose shielded containers that would be needed to assure that the NTF operation and the tank demolition operation could both 
proceed without interruption. The capital estimate identifies costs for 250 containers (with a 50 percent contingency) to support the AX Tank Farm closure project. The receiving hopper inside the NTF is sized to accommodate the contents of approximately 190 boxes, providing some degree of surge separation between the two operations. However, if either operation were to be idled for a period of several days or longer, the other would become impacted by the nonavailability of containers to load or unload. At the current level of study detail, this issue may seem inconsequential, though, at some point in the design cycle, there would be significant cost/risk incentives involved in providing an accurate forecast for the number of containers required. Because of the high unit cost of containers, procuring an excessive number would be undesirable. Alternatively, if operations are idled by an interruption in the flow of containers, significant penalties in nonproductive labor costs could be incurred. The eventual decision regarding the appropriate number of containers to support the operation may be driven by considerations (e.g., risk minimization) that cannot be quantified at the present time.

\subsection{APPLICATIONS FOR ROBOTICS AND/OR REMOTE-OPERATED EQUIPMENT}

The focus of this study was to develop a process concept for treatment (i.e., partial decontamination) of highly radioactive debris from demolition of AX tanks and ancillary equipment. Conceptualization did not include specific consideration of robotics or remoteoperated equipment applications. However, certain aspects of the NTF operation could benefit from these types of provisions. The capital cost estimate includes an allowance of $\$ 22$ million with a 50-percent contingency for specialized equipment (e.g., robotic equipment, manipulators, glove boxes, leaded glass viewing windows). The cost basis for the allowance is the cost entry for similar equipment in the earlier study estimate (Boomer et al 1991). None of these types of equipment items were detailed out in either the previous study or the current study.

\subsection{CLOSED-LOOP OPERATION}

The proposed process logic (Figure 3.1) offers a high degree of flexibility for optimization. Closed-loop operation is shown for the autogenous grinding step for coarse soil and concrete debris. Similar closed-loop strategies could also be applied to enhance decontamination factors for the metal acid washing and/or fine-solids filtration aspects of the process. If target decontamination factors are achievable while operating in open-loop (single-pass) mode, that would clearly be preferred. Operating in closed-loop mode would negatively impact the plant throughput rate and secondary waste generation (i.e., by increasing volumes of wash water and evaporator condensate). This flexibility enhances overall confidence in the basic workability of the proposed processing concept. However, the details involved in optimizing the process are not currently foreseeable. 


\subsection{REFERENCES}

Boomer, K.D., S.K. Baker, A.L. Boldt, M.D. Britton, L.E. Engelsman, J.D. Galbraith, J.S. Garfield, K.A. Giese, C.E. Goldberg, B.A. Higley, K.J. Hull, L.J. Johnson, R.P. Knight, J.S. Layman, R.S. Marusich, R.J. Parazin, M.G. Piepho, E.J. Slaathaug, T.L. Waldo, C.E. Worcester, 1991. Systems Engineering Study for the Closure of Single-Shell Tanks, Appendix J, WHC-EP0405 (Draft A), Westinghouse Hanford Co., Richland, Washington.

FDH 1998. Hanford Site Solid Waste Acceptance Criteria, HNF-EP-0063 Rev. 5, Fluor- Daniel Hanford Co., Richland, Washington.

Hendrickson, D.W., T.W. Staehr, S.L. Lambert, D.C. Ramsower, 1998. AX Tank Farm Waste Inventory Study for the Hanford Tanks Initiative (HTI) Project, HNF-SD-HTI-TI- 001 Rev. 0A, COGEMA Engineering Corp., Richland, Washington.

JEG, 1997. Hanford Tanks Initiative, Retrieval Performance Evaluation Criteria Assessment: Work Plan, Jacobs Engineering Group, Richland, Washington.

Schaus, S., 1997. Hanford Tanks Initiative Plan, HNF-SD-HTI-PLN-002, Lockheed- Martin Hanford Co., Richland, Washington.

Skelly, W.A., 1998. AX Tank Farm Tank Removal Study, HNF-3378, COGEMA Engineering Corp., Richland, Washington.

Skelly, W.A., 1998. AX Tank Farm Ancillary Equipment Study, HNF-3441, COGEMA Engineering Corp., Richland, Washington.

WHC 1995. Radioactive Hazardous Materials Packaging Directory, Rev. 1, WHC-SP- 1070, Westinghouse Hanford Co., Richland, Washington. 
HNF-4098, Rev. 0

APPENDIX A

\section{PRE-PROCESSING FACILITY}

MATERIAL BALANCE 


\begin{tabular}{|l|c|r|r|r|r|r|r|r|}
\hline STREAM NUMBER & \multicolumn{1}{|c|}{81} & \multicolumn{1}{|c|}{82} & 87 & 88 & 89 & 91 & 92 & \multicolumn{1}{c|}{93} \\
\hline DESCRIPTION & $\begin{array}{l}\text { Wash } \\
\text { Acid }\end{array}$ & $\begin{array}{l}\text { Digester } \\
\text { Acid }\end{array}$ & Caustic & Solidifier & Caustic & $\begin{array}{l}\text { Wash } \\
\text { Water }\end{array}$ & $\begin{array}{l}\text { Rinse } \\
\text { Water }\end{array}$ & $\begin{array}{l}\text { Grinder } \\
\text { Water }\end{array}$ \\
\hline Vol, $\mathrm{m3}$ & 157.6632 & 1771.715 & 40.11608 & 350.0093 & 248.9478 & 1121.988 & 2758.094 & 6297.446 \\
Density, $\mathrm{kg} / \mathrm{l}$ & 1.35 & 1.35 & 1.53 & 1.4 & 1.53 & 1 & 1 & 1 \\
\hline
\end{tabular}

\begin{tabular}{|c|c|c|c|c|c|c|c|c|}
\hline \multicolumn{9}{|c|}{$\begin{array}{l}\text { COMPONENTS, } \mathrm{kg} \\
\text { Aggregate } \\
\text { Sand/fines } \\
\text { cement }\end{array}$} \\
\hline $\begin{array}{l}\text { metal } \\
\text { tank waste } \\
\text { water }\end{array}$ & 91496.79 & 1028180 & 30688.8 & & 190445 & 1121988 & 2758094 & 6297446 \\
\hline $\begin{array}{l}\text { dissolved so } \\
\text { suspended }\end{array}$ & & & & & & & & \\
\hline $\begin{array}{l}\text { acid/caustic } \\
\text { other }\end{array}$ & 121348.5 & 1363634 & 30688.8 & 490013 & 190445 & & & \\
\hline TOTAL, $\mathrm{kg}$ & 212845.3 & 2391815 & 61377.6 & 490013 & 380890.1 & 1121988 & 2758094 & 6297446 \\
\hline
\end{tabular}

\section{RADIONUCLIDES}

$$
\begin{aligned}
& \mathrm{Sr}, \mathrm{Ci} \\
& \mathrm{Cs}, \mathrm{Ci} \\
& \mathrm{TRU}, \mathrm{Ci}
\end{aligned}
$$

Cat-1 Index

Cat-3 Index

TRU Index

Ci fraction solid

Ci fraction liquid
NOTES

(11)

(8)

(11)

(13)

(13) 


\begin{tabular}{|c|c|c|c|c|c|c|c|c|c|c|c|}
\hline STREAM NUMBER & 101 & 102 & 103 & 104 & 105 & 106 & 107 & 109 & 111 & 112 & 113 \\
\hline DESCRIPTION & $\begin{array}{l}\text { Ancillary } \\
\text { Scabbling }\end{array}$ & $\begin{array}{l}\text { Ancillary } \\
\text { Metal }\end{array}$ & $\begin{array}{l}\text { Tank } \\
\text { Soil }\end{array}$ & $\begin{array}{l}\text { Tank } \\
\text { Concrete }\end{array}$ & $\begin{array}{l}\text { Tank } \\
\text { Metal }\end{array}$ & $\begin{array}{l}\text { Tank } \\
\text { Grout }\end{array}$ & $\begin{array}{l}\text { Tank } \\
\text { Waste }\end{array}$ & $\begin{array}{l}\text { Consolidat } \\
\text { Rubble Fe }\end{array}$ & $\begin{array}{l}\text { Consolidat } \\
\text { Metal Fee }\end{array}$ & $\begin{array}{l}\text { Etched } \\
\text { Metal }\end{array}$ & $\begin{array}{l}\text { Rinsed } \\
\text { Metal }\end{array}$ \\
\hline $\begin{array}{l}\text { Vol, m3 } \\
\text { Density, kg/l }\end{array}$ & $\begin{array}{l}4.33 \\
1.35\end{array}$ & $\begin{array}{r}241 \\
1.57\end{array}$ & $\begin{array}{r}192.8947 \\
1.52\end{array}$ & $\begin{array}{r}3762.963 \\
1.35 \\
\end{array}$ & $\begin{array}{r}1515.924 \\
1.57\end{array}$ & $\begin{array}{r}640 \\
1.35\end{array}$ & $\begin{array}{r}83.69231 \\
0.65\end{array}$ & $\begin{array}{r}4683.88 \\
1.344493\end{array}$ & $\begin{array}{r}1756.924 \\
1.57\end{array}$ & $\begin{array}{r}1756.748 \\
1.57\end{array}$ & $\begin{array}{r}1756.748 \\
1.57\end{array}$ \\
\hline
\end{tabular}

\begin{tabular}{|c|c|c|c|c|c|c|c|c|c|c|c|}
\hline $\begin{array}{l}\text { COMPONENTS, } \mathrm{kg} \\
\text { Aggregate } \\
\text { Sand/fines } \\
\text { cement }\end{array}$ & $\begin{array}{r}3507.3 \\
1461.375 \\
876.825\end{array}$ & & 293200 & $\begin{array}{r}3048000 \\
1270000 \\
762000\end{array}$ & & $\begin{array}{r}768960 \\
95040\end{array}$ & & $\begin{array}{r}3051507 \\
2333621 \\
857916.8\end{array}$ & & & \\
\hline $\begin{array}{l}\text { metal } \\
\text { tank waste } \\
\text { water }\end{array}$ & & 378370 & & & 2380000 & & 54400 & $\begin{array}{r}0 \\
54400\end{array}$ & 2758370 & $\begin{array}{r}2730786 \\
24349.19\end{array}$ & $\begin{array}{r}2730786 \\
27278.86\end{array}$ \\
\hline $\begin{array}{l}\text { dissolved solids } \\
\text { suspended solids }\end{array}$ & & & & & & & & & & 2396.765 & 23.4977 \\
\hline $\begin{array}{l}\text { acid/caustic } \\
\text { other }\end{array}$ & & & & & & & & & & 561.9045 & 5.508867 \\
\hline TOTAL, $\mathrm{kg}$ & 5845.5 & 378370 & 293200 & 5080000 & 2380000 & 864000 & 54400 & 6297446 & 2758370 & 2758094 & 2758094 \\
\hline
\end{tabular}

RADIONUCLIDES

\begin{tabular}{|c|c|c|c|c|c|c|c|c|c|c|c|}
\hline $\begin{array}{l}\mathrm{Sr}, \mathrm{Ci} \\
\mathrm{Cs}, \mathrm{Ci} \\
\text { TRU, Ci }\end{array}$ & $\begin{array}{r}49326 \\
2346 \\
60.9 \\
\end{array}$ & $\begin{array}{r}49326 \\
2346 \\
60.9 \\
\end{array}$ & \begin{tabular}{r|}
5997 \\
300 \\
5.737 \\
\end{tabular} & $\begin{array}{r}5997 \\
300 \\
5.737 \\
\end{array}$ & $\begin{array}{r}17991 \\
898 \\
17.21\end{array}$ & $\begin{array}{r}29985 \\
1496 \\
28.69 \\
\end{array}$ & $\begin{array}{r}1139434 \\
56858 \\
1090\end{array}$ & $\begin{array}{r}1230739 \\
61300 \\
1191.064\end{array}$ & $\begin{array}{r}67317 \\
3244 \\
78.11\end{array}$ & $\begin{array}{r}1350.75 \\
65.0925 \\
1.567317\end{array}$ & $\begin{array}{l}13.24264 \\
0.638162 \\
0.015366\end{array}$ \\
\hline Cat-1 Index & 810489.7 & 14561.91 & 2225.867 & 114.101 & 849.4559 & 3353.223 & 974431.8 & 18802.07 & 2730.415 & 54.79264 & 0.5371 \\
\hline Cat-3 Index & 0.256107 & 0.004601 & 0.000705 & $3.62 E-05$ & 0.000269 & 0.001062 & 0.308736 & 0.005957 & 0.000863 & 1.73E-05 & 1.7E-07 \\
\hline TRU index & 104.1827 & 1.609536 & 0.195668 & 0.011293 & 0.072311 & 0.33206 & 200.3676 & 1.891345 & 0.283174 & 0.005683 & 5.57E-05 \\
\hline $\begin{array}{l}\text { Ci fraction solid } \\
\mathrm{Ci} \text { fraction liquid }\end{array}$ & & & $\begin{array}{l}1 \\
0\end{array}$ & & & 0 & & $\begin{array}{l}1 \\
0\end{array}$ & & & \\
\hline
\end{tabular}
NOTES
$(2,3,5,6)$
$(2,4,6)$
$(2,7)$
$(2,3,5)$
$(2,4)$
$(2,8)$
$(2,9)$
$(4,10,12)$
$(4,12)$ 


\begin{tabular}{|c|c|c|c|c|c|c|c|c|c|c|c|}
\hline STREAM NUMBER & 114 & 115 & 121 & 122 & 123 & 124 & 125 & 126 & 131 & 132 & 133 \\
\hline DESCRIPTION & \begin{tabular}{|l|} 
Metal \\
Rinse Ret
\end{tabular} & $\begin{array}{l}\text { Metal } \\
\text { Wash Ret }\end{array}$ & $\begin{array}{l}\text { Rubble } \\
\text { Course }\end{array}$ & $\begin{array}{l}\text { Rubble } \\
\text { Returns }\end{array}$ & $\begin{array}{l}\text { Rubble } \\
\text { Wet }\end{array}$ & $\begin{array}{l}\text { Rubble } \\
\text { Released }\end{array}$ & $\begin{array}{l}\text { Dryer } \\
\text { Off-Gas }\end{array}$ & $\begin{array}{l}\text { Rubble } \\
\text { Fines }\end{array}$ & & $\begin{array}{l}\text { Digester } \\
\text { Underflow }\end{array}$ & $\begin{array}{l}\text { Filter } \\
\text { Liquid }\end{array}$ \\
\hline $\begin{array}{l}\text { Vol, m3 } \\
\text { Density, kg/l }\end{array}$ & 2758.094 & $\begin{array}{r}1212.389 \\
1.1 \\
\end{array}$ & $\begin{array}{r}2283.218 \\
1.35 \\
\end{array}$ & $\begin{array}{r}0.228322 \\
1.35 \\
\end{array}$ & $\begin{array}{r}2282.99 \\
1.35 \\
\end{array}$ & $\begin{array}{r}4283.191 \\
1.35\end{array}$ & $\begin{array}{r}2284882 \\
0.00129\end{array}$ & $\begin{array}{r}7046.331 \\
1.35 \\
\end{array}$ & $\begin{array}{r}4529.967 \\
1.1 \\
\end{array}$ & $\begin{array}{r}7025.899 \\
1.1\end{array}$ & 3513.301 \\
\hline
\end{tabular}

\begin{tabular}{|c|c|c|c|c|c|c|c|c|c|c|c|}
\hline $\begin{array}{l}\text { COMPONENTS, kg } \\
\text { Aggregate } \\
\text { Sand/fines } \\
\text { cement }\end{array}$ & & & $\begin{array}{r}3051507 \\
233.3621 \\
85.79168 \\
\end{array}$ & $\begin{array}{l}305.1507 \\
0.023336 \\
0.008579 \\
\end{array}$ & $\begin{array}{r}3051202 \\
233.3388 \\
85.7831 \\
\end{array}$ & $\begin{array}{r}3051202 \\
233.3388 \\
85.7831 \\
\end{array}$ & & $\begin{array}{r}2333388 \\
857831 \\
\end{array}$ & $\begin{array}{r}23333.88 \\
85.7831 \\
\end{array}$ & $\begin{array}{r}2310054 \\
8492.527\end{array}$ & $\begin{array}{l}231.0054 \\
0.849253\end{array}$ \\
\hline $\begin{array}{l}\text { metal } \\
\text { tank waste } \\
\text { water }\end{array}$ & 2755164 & 1189136 & 30518.26 & 3.051826 & 30515.21 & 2730786 & 57794.07 & $\begin{array}{r}54400 \\
6266927 \\
\end{array}$ & 4057865 & 4426378 & 3161825 \\
\hline $\begin{array}{l}\text { dissolved solids } \\
\text { suspended solids }\end{array}$ & 2373.268 & 117050.3 & & & & & & & 748141.3 & 816083.4 & 582940 \\
\hline $\begin{array}{l}\text { acid/caustic } \\
\text { other }\end{array}$ & 556.3956 & 27441.6 & & & & & 2889703 & & 153537.1 & 167480.5 & 119633.7 \\
\hline TOTAL, $\mathrm{kg}$ & 2758094 & 1333628 & 3082345 & 308.2345 & 3082036 & 5782308 & 2947498 & 9512546 & 4982963 & 7728489 & 3864631 \\
\hline
\end{tabular}

RADIONUCLIDES

\begin{tabular}{|c|c|c|c|c|c|c|c|c|c|c|c|}
\hline $\begin{array}{l}\mathrm{Sr}, \mathrm{Ci} \\
\mathrm{Cs}, \mathrm{Ci} \\
\mathrm{TRU}, \mathrm{Ci}\end{array}$ & $\begin{array}{l}1337.507 \\
64.45433 \\
1.551951\end{array}$ & $\begin{array}{l}65966.25 \\
3178.908 \\
76.54268\end{array}$ & $\begin{array}{r}9.1305 \\
0.4442 \\
0.010106\end{array}$ & $\begin{array}{l}0.000913 \\
4.44 \mathrm{E}-05 \\
1.01 \mathrm{E}-06\end{array}$ & $\begin{array}{l}9.129587 \\
0.444156 \\
0.010105\end{array}$ & $\begin{array}{l}22.34986 \\
1.081235 \\
0.025446\end{array}$ & $\begin{array}{l}0.022372 \\
0.001082 \\
2.55 E-05\end{array}$ & $\begin{array}{r}1230730 \\
61299.56 \\
1191.054\end{array}$ & $\begin{array}{l}619759.5 \\
30817.66 \\
605.8513\end{array}$ & $\begin{array}{r}676936.6 \\
33660.8 \\
661.7452\end{array}$ & $\begin{array}{r}482899.9 \\
24012.29 \\
472.063\end{array}$ \\
\hline Cat-1 Index & 34.55761 & 3877.364 & 0.285308 & 0.285308 & 0.285308 & 0.372025 & $6.98 \mathrm{E}-07$ & 12498.13 & 9787.75 & 6892.88 & 9833.236 \\
\hline Cat-3 Index & $1.09 \mathrm{E}-05$ & 0.001226 & $9.03 E-08$ & 9.03E-08 & $9.03 \mathrm{E}-08$ & $1.18 \mathrm{E}-07$ & $2.21 \mathrm{E}-13$ & 0.003959 & 0.003101 & 0.002183 & 0.003115 \\
\hline TRU Index & 0.005627 & 0.573943 & $3.28 E-05$ & 3.28E-05 & $3.28 \mathrm{E}-05$ & 4.4E-05 & 8.64E-08 & 1.252087 & 1.215845 & 0.856241 & 1.221496 \\
\hline $\begin{array}{l}\text { Ci fraction solid } \\
\mathrm{Ci} \text { fraction liquid }\end{array}$ & & $\begin{array}{l}0 \\
1\end{array}$ & $\begin{array}{l}1 \\
0\end{array}$ & 0 & 0 & $\begin{array}{l}1 \\
0\end{array}$ & 0 & 0 & $\begin{array}{l}1.47 E-05 \\
0.999985\end{array}$ & $\begin{array}{l}0.001335 \\
0.998665\end{array}$ & 1.87E-07 \\
\hline
\end{tabular}
NOTES
$(10,12,14)(3,12,15) \quad(3,16)$
$(3,16)$
$(3,17)$
(17)
$(3,15)$
$(14,21)$
$(14,20,21)(14,24)$ 


\begin{tabular}{|l|r|l|l|r|r|r|r|}
\hline STREAM NUMBER & \multicolumn{1}{|c|}{134} & \multicolumn{1}{|c|}{135} & \multicolumn{1}{|c|}{136} & \multicolumn{1}{c|}{137} & \multicolumn{1}{c|}{151} & \multicolumn{1}{c|}{152} & \multicolumn{1}{c|}{153} \\
\hline DESCRIPTION & $\begin{array}{l}\text { Centrifuge } \\
\text { Overflow }\end{array}$ & $\begin{array}{l}\text { Centrifuge } \\
\text { Cake }\end{array}$ & $\begin{array}{l}\text { Filter } \\
\text { Cake }\end{array}$ & $\begin{array}{l}\text { Solidifed } \\
\text { Solids }\end{array}$ & $\begin{array}{l}\text { Evaporato } \\
\text { Condensa }\end{array}$ & $\begin{array}{l}\text { Evaporato } \\
\text { Cottoms }\end{array}$ & $\begin{array}{l}\text { DST } \\
\text { Returns }\end{array}$ \\
\hline Vol, m3 & 8007.435 & 30.31943 & 2972.198 & 1979.851 & 4804.712 & 3639.513 & 3987.351 \\
Density, kg/l & 1.1 & 1.3 & 1.3 & 2.25 & 1 & 1.1 & 1.1 \\
\hline
\end{tabular}

\begin{tabular}{|l|r|r|r|r|r|r|r|}
\hline $\begin{array}{l}\text { COMPONENTS, } \mathrm{kg} \\
\text { Aggregate } \\
\text { Sand/fines } \\
\text { cement }\end{array}$ & 2.356489 & 23562.53 & 2309823 & 2333386 & & & \\
\hline $\begin{array}{l}\text { metal } \\
\text { tank waste } \\
\text { water }\end{array}$ & 0.008663 & 86.62369 & 8491.678 & 8578.302 & & & \\
\hline $\begin{array}{l}\text { dissolved solids } \\
\text { suspended solids }\end{array}$ & 7206791 & 12899.72 & 1264553 & 1321952 & 4804712 & 2402079 & 2670433 \\
\hline $\begin{array}{l}\text { acid/caustic } \\
\text { other }\end{array}$ & 1328703 & 2378.298 & 233143.4 & 300735.4 & & 1328703 & 1696608 \\
\hline TOTAL, kg & 272682.7 & 488.0854 & 47846.78 & 490013 & & 272682.7 & 19044.5 \\
\hline
\end{tabular}

\section{RADIONUCLIDES}

\begin{tabular}{|c|c|c|c|c|c|c|c|}
\hline $\begin{array}{l}\mathrm{Sr}, \mathrm{Ci} \\
\mathrm{Cs}, \mathrm{Ci} \\
\mathrm{TRU}, \mathrm{Ci}\end{array}$ & $\begin{array}{r}1100680 \\
54731.53 \\
1075.979\end{array}$ & $\begin{array}{r}1979.37 \\
98.42453 \\
1.93495 \\
\end{array}$ & $\begin{array}{l}194036.6 \\
8648.509 \\
189.6822\end{array}$ & $\begin{array}{r}196016 \\
9746.934 \\
191.6172\end{array}$ & $\begin{array}{r}733.815 \\
36.48909 \\
0.717347\end{array}$ & $\begin{array}{r}1099946 \\
54695.04 \\
1075.262\end{array}$ & $\begin{array}{r}1099946 \\
54695.04 \\
1075.262\end{array}$ \\
\hline Cat-1 Index & 9833.822 & 4670.47 & 4670.47 & 7082.944 & 10.92632 & 21621.35 & 19735.21 \\
\hline Cat-3 Index & 0.003115 & 0.001479 & 0.001479 & 0.002244 & $3.46 E-06$ & 0.006849 & 0.006252 \\
\hline TRU Index & 1.221569 & 0.490914 & 0.490914 & 0.43015 & 0.001493 & 2.685829 & 2.45153 \\
\hline $\begin{array}{l}\text { Ci fraction solid } \\
\mathrm{Ci} \text { fraction liquid }\end{array}$ & $8.38 \mathrm{E}-10$ & $\begin{array}{l}0.004658 \\
0.995342\end{array}$ & $\begin{array}{l}0.004658 \\
0.995342\end{array}$ & 0 & $\overline{0}$ & 0 & \\
\hline
\end{tabular}
NOTES
$(14,24) \quad(22,23,24)(22,23,24)(8,25,26) \quad(17)$
$(14,27)$
$(14,28)$ 


\section{MATERIAL BALANCE}

\section{NOTES-ASSUMPTIONS-REFERENCES}

(2) from this report, SESC-EP-xxx, Rev 0 , Jan 99, Table 2.4, Totals column, pgs xxx

1.35 concrete density at 2.25 and $60 \%$ packing density

1.57 steel density at 7.86 and $20 \%$ packing density

0.6 fraction of aggregate in concrete

0.25 fraction of sand in concrete

0.15 fraction of cement in concrete $50 / 50$ fraction, no basis

1.52 soil density at $100 \%$ packing density

0.89 fraction of sand in grout

0.11 fraction of cement in grout

$0.65 \mathrm{~kg} / \mathrm{l}$ as average waste density of 1.3 with 0.50 packing fraction

0.01 metal fraction dissolved in wash, $\mathrm{Fe}+3 \mathrm{HNO} \rightarrow \mathrm{Fe}(\mathrm{NO}) 3$ or $55.85+189=241.85$

0.1 acid concentration in wash

0.01 liquid drag-out on a weight fraction basis

1 ratio of rinse liquid to incoming solids

1.1 general solution density

0.9999 fraction of cement converted to fines

0.0001 fraction failing survey, needing recycle

0.001 fraction carry over of dust or vapor

0.99 cement fraction dissoived in digester, $\mathrm{CaCO} 3+2 \mathrm{HNO} 3 \rightarrow \mathrm{Ca}(\mathrm{NO} 3) 2$ or $100+126=164$

1.3 excess acid ratio to dissolver \& acid wash

0.3 slurry fraction in digester underflow

0.01 solids carry over in digester overflow

0.6 solids fraction in filter/centrifuge cake

1.3 filter/centrifuge cake density

0.0001 filter - centrifuge solids carry through

2.25 solidified grout density

neutralization, $\mathrm{HNO} 3+\mathrm{NaOH} \rightarrow \mathrm{NaNO} 3+\mathrm{H} 2 \mathrm{O}$ or $63+40=85+18$

0.4 solution solubility limit

1.1 neutralization excess 
HNF-4098, Rev. 0

\author{
APPENDIX B \\ CAPITAL COST ESTIMATE \\ FOR \\ PROPOSED NEW TREATMENT FACILITY
}

B-1 
FLUOR DANIEL NORTKHEST, INC.

COGEMA ENGINEERING

JOB NO. 2649 SAA2

FILE NO. Z649SAA2

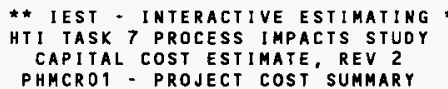

PAGE 1 OF 14

DATE $02 / 12 / 99 \quad 15: 37: 34$

BY R.OHRT

\begin{tabular}{|c|c|}
\hline $\begin{array}{l}\text { SORT } \\
======\end{array}$ & 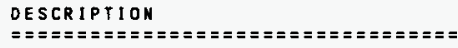 \\
\hline $\mathrm{Nu}$ & FLUOR DAN1EL NORTHHEST \\
\hline
\end{tabular}

SUBTOTAL

SITE SITE ALLOCATIONS

PROJECT TOTAL

\begin{tabular}{|c|c|c|c|}
\hline ESCALATED & cor & IGENCY & TOTAL \\
\hline IOTAL COST & $x$ & IOTAL & DOLLARS \\
\hline$===$ = = = = = = = = & $==\mathbf{=}=$ & 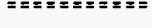 & 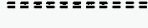 \\
\hline $474,590,000$ & 42 & $200,450,000$ & $675,040,000$ \\
\hline
\end{tabular}

$474,590,000 \quad 42 \quad 200,450,000 \quad 675,040,000$

$87,210,000 \quad 42 \quad 36,690,000 \quad 123,900,000$

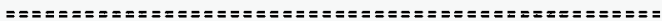

$561,800,000 \quad 42 \quad 237,140,000 \quad 798,940,000$

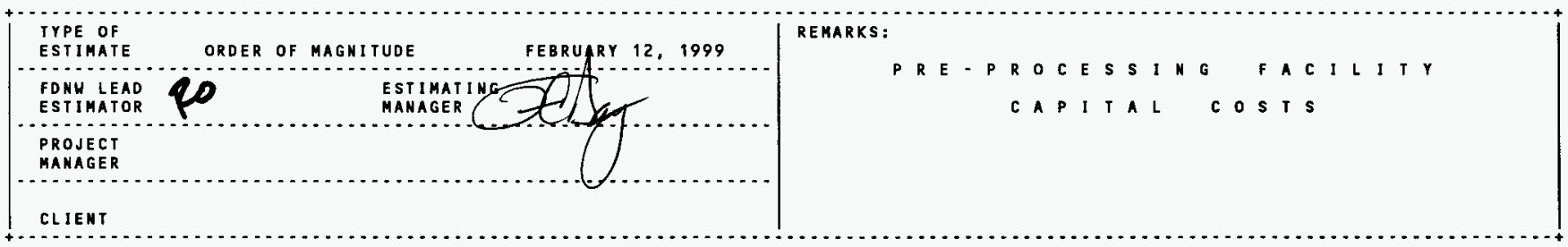

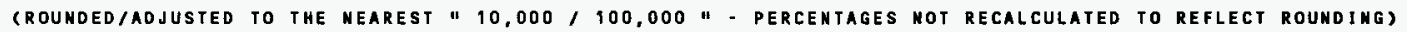


FLUOR OANIEL NORTHHEST, INC. COGEMA ENGINEER ING JOB NO. 2649SAA2

FILE NO. Z649SAA
* * IEST - INTERACTIVE ESTIMATING * *

HTI TASK 7 PROCESS IMPACTS STUDY

CAPITAL COST ESTIMATE, REV 2

PHMCRO2 - WORK BREAKDOHN STRUCTÚRE (HBS) SUMMARY
PAGE 2 OF 14

DATE $02 / 12 / 99$ 15:37:38

BY R.OHRT
HBS DESCRIPTION

110000 DEFINITIVE DESIGN

120000 ENGINEER ING/INSPECTION

130000 PILOT PLANT

140000 PERMITTING

150000 SAFETY ANALYSIS

160000 CONSTRUCIION MANAGERENT

SUBTOTAL 1 ENGINEERING

320001 SITEWORK

320002 STRUCTURES

320003 FIRE PROTECTION \& DETECTION

320004 HVAC

320005 NORHAL ELECTRICAL OISTRIBUTION

320006 STANDBY ELECTRICAL DISTRIBUTION

320007 UNINTERRUPTABLE POWER SOURCE

320008 PROCESS EQUIPMENT DECON AND REPAIR

320009 COMPRESSED AIR AND GAS

320010 PROCESS AIR

320011 RAH WATER \& FIREWATER

320012 DISTRIBUTEO CONTROL SYSTEM

320013 COMMUNICATIONS

320014 ANALYTICAL FACILITIES

320016 STACK \& FANHOUSE

320017 HEALTH PHYSICS MONITORING EQUIPMENT

SUBTOTAL 320 BUILDING
ESTIMATE
SUBTOTAL

SUBTOTAL ESCALATIO

46618102

15539367

28438322

2496000

19737120

50977052

163805963

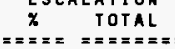

0.00

0.00

0.00

0.00

0.00

0.00

0.00

991397

27754710

930702

10603688

4776047

11391309
867557

10483531

285189

296902

442366

15559374

563777

3766581

14440582

2647625

195801337

0.00

0.00

0.00

0.00

0.00
0.00

0.00

0.00

0.00

0.00

0.00

0.00

0.00

0.00

0.00

0.00

2520101

21236454

2412132

2737558

3096900

22000000

18485871

2236343

0884500

650550

675296

0.00

0.00

0.00

0.00

0.00

0.00

0.00

0.00

0.00

0.00
0.00
SUB TOTAL

\section{2}

15539367

28438322

2496000

19737120

5097705

163805963

991397

27754710

930702

10603688

4776047

11391309

867557

10483531

285189

296902

442366

442366
15559374

5559374
563777

563777
13766581

13766581

14440582
2647625

15801337

2520101

21236454

2412132

2737558

3096900

22000000

1848587

2236343

20884500
650550

675296

\begin{tabular}{|c|c|c|}
\hline $\begin{array}{l}\text { CON } \\
x\end{array}$ & $\begin{array}{l}\text { INGENCY } \\
\text { TOTAL } \\
==\approx=\equiv=\equiv=\end{array}$ & $\begin{array}{c}\text { SUB } \\
\text { TOTAL } \\
=\approx=\approx \equiv=\equiv \equiv=\end{array}$ \\
\hline $\begin{array}{l}35 \\
35 \\
35 \\
35 \\
35 \\
45\end{array}$ & $\begin{array}{r}16316335 \\
5438778 \\
9953412 \\
873600 \\
6907992 \\
22939673\end{array}$ & $\begin{array}{r}62934437 \\
20978145 \\
38391734 \\
3369600 \\
26645112 \\
73916725\end{array}$ \\
\hline 38 & 62429792 & 226235755 \\
\hline
\end{tabular}

SITE

ALLOCAT'

TOTAL

$== \pm= \pm== \pm \quad$ DOLLARS

13530904

4510301

8254222

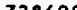

15892095

48640687

76465341

25488446

46645957

4094064

32373811

89808821

274876442

210126

5882610

197262

3738385

1256447

9714148

325745

3711290

1671616

14314978

6447663

15378267

1171201

303644

3669235

99816

14152766

400817

597194

154828

54028

5445780
197321

818303

5054203

21005154

761098

18584884

19494785

3574293

224745

1012283

2414387

183878

2221984

60445

62928

93759

3297809

119492

2917826

3060681

561164

$40530467 \quad 156331804$

24544093

1548512

43351469

1453710

16562430

7459946

17792655

1355080

16374751

445450
463746

463746
690953

24302964

4302964
880591

21502711

22555467

4135457

180875898

593483

1260050

10618227

378015

31854681

3618198

4106337

1368779

1548450

4645350

11000000

9242935

33000000

27728806

27728806

1044250

3354514

0442250

31326750

975825
1012944

5001184

568057

36855865

4186255

644694
729319

751031
374669

5181000

4918299

38181000

32082229

32082229
3881173

3881173
36245049

153204

36245049

1129029
1171976

159032 
FLUOR DAKIEL NORTHUEST, INC.

COGEMA ENGINEERING

JOB NO. 2649 SAA2

FILE NO. Z649\$AA2

WBS DESCRIPTION

\section{SHIELDED WASTE CONTAIMERS}

325019 WASTE RECEIVIHG AREA

325023 SHREDDER

325024 ACID DIGESTER

325025 ROTARY DRUM FILTER

325026 CENTRI FUGE

325028 EVAPORATOR

325029 GRINDING MILL

325030 STAGING TANKS

325031 CAT 1 LOADING STATION

325032 CAT 3 CONCRETING/LOADING STATION

325033 JUMPERS

SUBTOTAL 325 SPECIAL EQUIPMENT

SUBTOTAL 32 FIXED PRICE CONSTRUCTION

\section{PROJECT MAHAGEMENT}

\begin{abstract}
SUBTOTAL 3 CONSTRUCTION
\end{abstract}
PROJECT TOTAL
* * IEST - INIERACTIVE ESTIMATING * *

HTI TASK 7 PROCESS IMPACTS STUDY

CAPITAL COST ESTIMATE, REV 2

PHMCRO2 - HORK BREAKDOWN STRUCTURE (HBS) SUMMARY
PAGE 3 OF 14

$15: 37: 38$

BY R.OHRT

\begin{tabular}{|c|c|c|c|c|c|c|c|c|}
\hline $\begin{array}{l}\text { ESTIMATE } \\
\text { SUBTOIAL } \\
=======\end{array}$ & $==\begin{array}{l}\text { ESCA } \\
x \\
===\end{array}$ & $\begin{array}{l}\text { LATION } \\
\text { TOTAL } \\
=======\end{array}$ & $\begin{array}{c}\text { SUB } \\
\text { TOTA } \\
========\end{array}$ & $== \pm= \pm$ & $\begin{array}{l}\text { I NGENCY } \\
\text { IOT AL } \\
=======\end{array}$ & $\begin{array}{c}\text { SUB } \\
\text { TOIAL } \\
==\approx======\end{array}$ & $\begin{array}{c}\text { SITE } \\
\text { ALLOCAT'N } \\
=========\end{array}$ & $\begin{array}{c}\text { TOTAL } \\
\text { DOLLARS } \\
=========\end{array}$ \\
\hline $\begin{array}{r}13750000 \\
2641421 \\
3991235 \\
1231200 \\
1717992 \\
717188 \\
13884750 \\
1944000 \\
1267555 \\
1825741 \\
342264 \\
1942463\end{array}$ & $\begin{array}{l}0.00 \\
0.00 \\
0.00 \\
0.00 \\
0.00 \\
0.00 \\
0.00 \\
0.00 \\
0.00 \\
0.00 \\
0.00 \\
0.00\end{array}$ & $\begin{array}{l}0 \\
0 \\
0 \\
0 \\
0 \\
0 \\
0 \\
0 \\
0 \\
0 \\
0 \\
0\end{array}$ & $\begin{array}{r}13750000 \\
2641421 \\
3991235 \\
1231200 \\
1717992 \\
717188 \\
13884750 \\
1944000 \\
1267555 \\
1825741 \\
342264 \\
1942463\end{array}$ & $\begin{array}{l}50 \\
50 \\
50 \\
50 \\
50 \\
50 \\
50 \\
50 \\
50 \\
50 \\
50 \\
50\end{array}$ & $\begin{array}{r}6875000 \\
1320710 \\
1995617 \\
615600 \\
858996 \\
358594 \\
6942375 \\
972000 \\
633777 \\
912870 \\
171132 \\
971231\end{array}$ & $\begin{array}{r}20625000 \\
3962131 \\
5986852 \\
1846800 \\
2576988 \\
1075782 \\
20827125 \\
2916000 \\
1901332 \\
2738611 \\
513396 \\
2913694\end{array}$ & $\begin{array}{r}3238125 \\
622054 \\
939935 \\
289947 \\
404587 \\
168897 \\
3269858 \\
457812 \\
298509 \\
429962 \\
80603 \\
457450\end{array}$ & $\begin{array}{r}23863125 \\
4584186 \\
6926788 \\
2136747 \\
2981575 \\
1244679 \\
24096983 \\
3373812 \\
2199841 \\
3168573 \\
593999 \\
3371144\end{array}$ \\
\hline 142191514 & 0.00 & 0 & 142191514 & 50 & 71095757 & 213287271 & 33486101 & 246773372 \\
\hline 257992851 & 0.00 & 0 & 257992851 & 43 & 111626224 & 369619075 & 58030195 & 427649270 \\
\hline 52794500 & 0.00 & 0 & 52794500 & 50 & 26397250 & 79191750 & 17224205 & 96415955 \\
\hline 310787351 & 0.00 & 0 & 310787351 & 44 & 138023474 & 448810825 & 75254400 & 524065226 \\
\hline & 0.00 & $\begin{array}{l}== \\
0 \\
4\end{array}$ & 593,314 & 4 & $200,453,267$ & 81 & 895,088 & $\begin{array}{l}== \\
69\end{array}$ \\
\hline
\end{tabular}


FLUOR DANIEL NORTKWEST, INC COGEMA ENG INEERING

JOB HO. 2649 SAA2

FILE NO. 2649SAA2
* * IEST - INTERACIIVE ESTIMAIING * *

HTI TASK 7 PROCESS IMPACTS STUDY CAPITAL COST ESTIMATE

PHMCROZ - ESTIMATE BASIS SHEET
PAGE 4 OF 14

DATE $02 / 12 / 99^{4} 12: 05: 00$

BY R.OHRT

1. ESTIMATE PURPOSE

ORDER OF MAGHITUDE ESTIMATE: THIS ESTIMATE HILL BE USED FOR BUDGETING PURPOSES ONLY.

2. ESTIMATE TECHNICAL BASIS

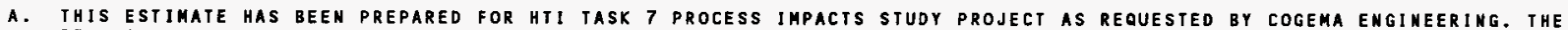
TECHNICAL SCOPE OF HORK WAS BEING DEVELOPED PARALLEL TO THE ESTIHATIMG EFFORT.

B. THIS ESTIMATE UTILIZES A HORK BREAKDOWH STRUCTURE SIMILAR TO EARLIER ESTIMATES DONE FOR THE CLIENT.

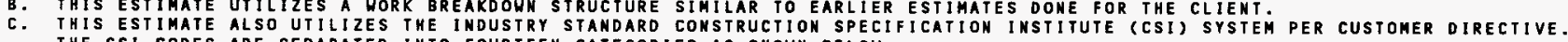
THE CSI CODES ARE SEPARATED INTO FOURTEEN CATEGORIES AS SHOWH BELOH:

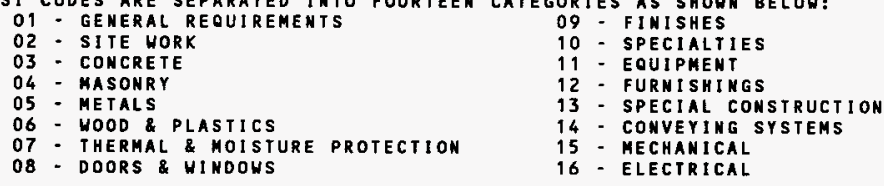

3. ESTIMATE METHODOLOGY

A. DIRECT COSTS:

A PARAMETRIC TECHHIOUE WAS UTILIZED IN THE REFERRENCED ESTIMATE WHICH WAS THE BASIS FOR MAHY OF THE COSTS FOR THIS ESTIMATE. THESE COSTS WERE ESCALATEO TO FY 1999 DOLLARS AND IM SOME CASES PRORATED TO REFLECT SIZE RATIOS.

(1) CONSTRUCIION LABOR, MATERIAL AND EQUIPMENT UNITS HAVE BEEN ESTIMATED BASED UPON ONE OR MORE OF THE FOLLOWING COMMERCIAL ESTIMATING RESOURCES, PUBLISHED ESTIMATIHG WAMUALS, IN HOUSE DATABASES, RICKARDSON'S PROCESS PLAHT CONSTRUCT ION ESTIMATING STANDARDS, PREVIOUS PARAMETRIC ESTIMATES, PRICE QUOTATIOH FROM VENDOR OR BEST GUESS ALLOHAHCE WHEN INSUFFICIENT INFORMATION IS AVAILABLE. SOME UNIT COSTS HAVE BEEN FACTORED/ADJUSTED AS APPROPRIATE TO REFLECT IHFLUENCES BY CONTRACT, WORK SITE, OR OTHER IDENTIFIED SPECIAL CONDITIONS.

B. DIRECT COST FACTORS:

(1) SALES TAX HAS BEEN APPLIED TO ALL MATERIALS AND EQUIPMENT PURCHASES AT 8\%.

(2) CONSTRUCTION MANAGEMENT FOR FIXED PRICE CONSTRUCTION HAS BEEN APPLIED AT I8.75\% OF CONSTRUCTION AND IS SHOHN IN WBS 130000 , AND IHCLUDES COSTS FOR BID PACKAGE PREPARATION, CONTRACT MANAGEMENT E ADHINISTRATION AND PROJECT MANAGEMENT \& PLANKING SUPPORT.

C. INDIRECT COSTS:

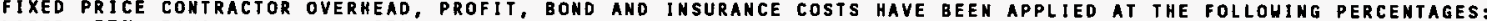
LABOR $=25 \%$, EQUIPMENT USE $=25 \%$, MATERIAL $=25 \%$, AND SUBCONTRACT $=10 X$, AND ARE REFLECTED IN THE

"OH\&P/B\&I" COLUMH OF THE ESTIMATE DETAIL REPORT.

D. RATES:

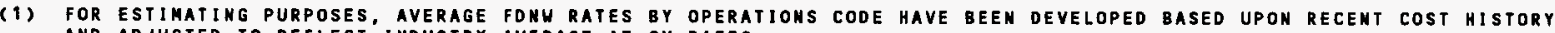
AND ADJUSTED TO REFLECT I MOUSTRY AVERAGE AE.CM RATES

(2) FIXED PRICE COHSTRUCTION CRAFT LABOR RATES ARE THOSE LISTED IM APPENDIX "A" OF THE HANFORD SITE STABILIZATION AGREEMENT (HSSA). THE HSSA RATES INCLUDE BASE HAGE, FRIMGE BEMEFITS AHD OTHER CONPENSATION AS NEGOTIATED BETHEEN FLUOR DANIEL HANFORD, INC. AND THE NATIOHAL BUILDIMG AND CONSTRUCTION TRADES DEPARTMENT, AFL-CIO. FLUOR DANIEL NORTHUEST INCORPORATES FACTORS TO COVER ADDITIONAL COSTS FOR YORKMAMS COMPEMSATION, FICA AND STATE AND FEDERAL UNEMPLOYMENT INSURANCE TO DEVELOPE A FULLY BURDENED RATE BY CRAFT. 
FLUOR DANIEL NORTHHEST, INC. COGEMA ENGINEER ING

JOB NO. Z649SAA2

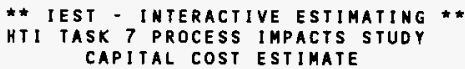

PHMCROZ - ESTIMATE BASIS SHEET
PAGE 5 OF 14

DATE 02/12/99 12:05:00

E. SITE ALLOCATIONS FACTORS:

SITE ALLOCATION FACTORS ARE DEVELOPED AND PROVIDED BY FLUOR DANIEL HANFORD (FDH) FOR ESTIMATING USE.

the above factors are applied to estimated COSTS as ShOHN in the phMCROG REPORT.

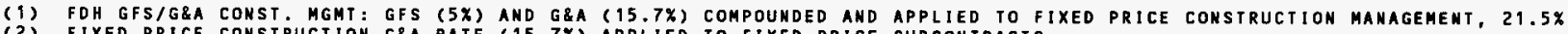

(2) FIXED PRICE CONSTRUCTION G\&A RATE (15.7\%) APPLIED TO FIXED PRICE SUBCONTRACTS.

(3) FDH GFS/G\&A - LABOR: GFS (5\%) AND G\&A (15.7\%) COMPOUNDED AND APPLIED TO HOME OFFICE ENGINEERING AT 21.5\%.

4. ESCALATION

ESCALATION HAS NOT BEEN INCLUDED AS ALL COSTS ARE IN CURRENT FEBRUARY 1999 DOLLARS

5. CONTINGENCY

A. DEFINITION OF CONIINGENCY AS PROVIDEO BY DOE

"CONTINGENCY COVERS COSTS THAT MAY RESULT FROM IMCOMPLETE DESIGN, UNFORESEEN AND UNPREDICTABLE CONDITIONS, OR UNCERTAINTIES WITHIN THE DEFIMED PROJECT SCOPE. THE AMOUNT OF CONTINGENCY WILL DEPEND ON THE STATUS OF DESIGN,

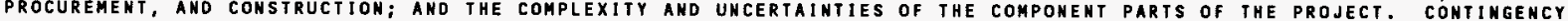

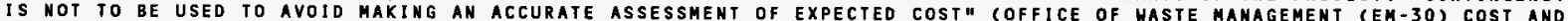
SCHEDULE GUIDE.

B. CONTINGENCY ALlOHANCE gUIDELIHES

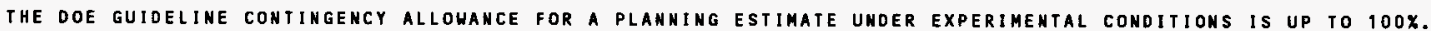

C. METHODOLOGY

CONTINGENCY IS EVALUATED AT THE LOWEST NORK BREAKOOUN STRUCTURE (WBS) LEVEL WITHIN THE COST ESTIMATE DETAILS. IT IS SUMMARIZED AT UPPER WBS LEVELS AND REPORTED ON THE SUMMARY REPORTS.

D. AMALYSIS

AN ASSESSMENT OF DESIGN MATURITY, WORK COKPLEXITY AND PROJECT UNCERTAINTIES HAS BEEN PERFORMED. ASSESSMENT AND CONTINGENCY RATES WHICH HAVE BEEN ADDED TO THE COST OF NORK ARE AS FOLLOUS:

WBS 110000 TO NBS 150000 , DESIGN, ENGINEERING INSPECTION PERMITTIMG SAFETY ANALYSIS AMD PILOT PLANTS HAVE ALL BEEM

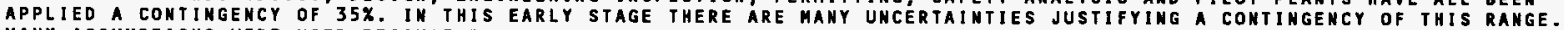
MANY ASSUMPTIONS WERE USED BECAUSE THERE IS STILL A LOT OF RESEARCH REQUIRED BEFORE THE PROCESS REOUIREMENTS ARE WELL

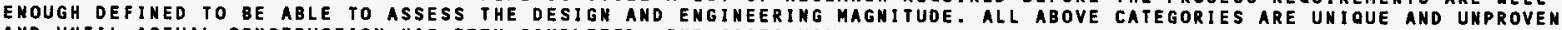
AMD UNTIL ACTUAL CONSTRUCTION HAS BEEN COMPLETED, THE COSTS HILL BE UNPREDICTABLE TOANY DEGREE OF CERTAINTY.

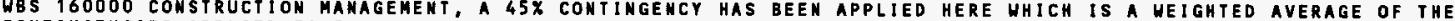
CONTINGENCIES APPLIED TO THE CONSTRUCTION ACTIVITIES (WBS $3200 X$ \& $3250 X$ S). THE REASON FOR THIS METHOD OF CONTIMGENCY APPLICATION IS IN KEEPING WITH THE NORMAL PROCEDURE OF CM BEIHG APPLIED AS A PERCENTAGE OF CONSTRUCTIOH (IM THIS CASE

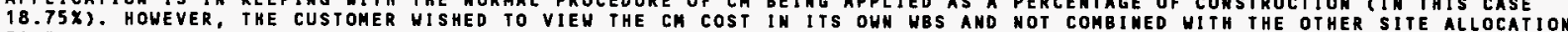
FACTORS. FOR THE CONTINGEMCY DOLLARS TO REMAIN UNCHANGED, THE WEIGHTED FACTOR WAS APPLIED. 
FLUOR DANIEL NORTHUEST, INC. COGEMA ENGINEERING

JOB NO. 2649SAA2

FILE NO. Z669SAA2

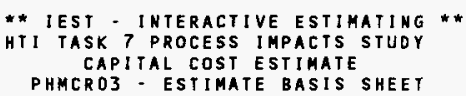

PAGE 6 OF 14

$\begin{array}{ll}\text { DATE } & 02 / 12 / 99^{\circ} 12: 05: 00 \\ \text { BY R.OHRT }\end{array}$

BY

WBS $3200 X X$ BUILDING CONSTRUCTION HAS A $35 \%$ CONTINGENCY APPLIED. THE INFORMATION ABLE AT THIS TIME IS PRELIHIMARY, THE BUILDING FOOTPRINT ITSELF IS SUBJECT TO ADJUSTMENT ONCE EQUIPMENT SI $2 E S$, QUANTITIES AND LOCATION BECOME CLEARER. GIVEN THE LACK OF DESIGN AND DRAWINGS, COSTS WERE ESTIMATED BY THE SQUARE FODT METHOD (ASSUMING A 1GO, OOO SF BUILDING). THE SOUARE FOOT COSTS NERE BASED ON EARLIER PARAMETRIC STUDIES. DUE TO THE COMBINATION OF VARIABLES, A 35X CONTINGENCY WAS FELT JUSTIFIED.

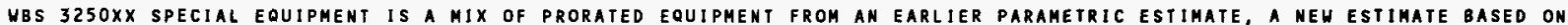
A VENDOR QUOTE, A BOTTOMS UP ESTIMATE OR A COMBINATION. SINCE NONE OF THE EQUIPMENT HAS BEEN DESIGNED AND DETAILS ARE

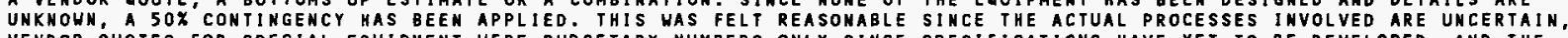

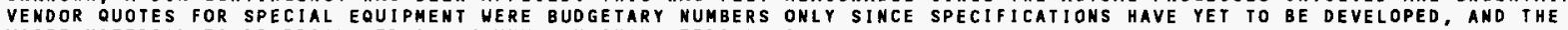
WASTE MATERIAL TO BE PROCESSED IS OF UNKMOWH CHARACTERISTICS.

\section{ROUNOING}

THE PROJECT COST SUMMARY REPORT IS SUMMARIZED AMD AOJUSTED/ROUNDED AS FOLLOWS:

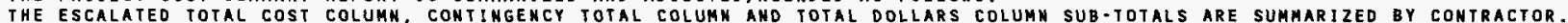
THE COLUMN SUBTOTALS ARE ADJUSTED/ROUNDED TO THE NEAREST \$1,OOO/\$1O, ODO. THE PROJECT TOIAL SUMMARY LINE TOTALS ARE THE COLUMN SUBTOTALS ARE ADJUSTED/ROUNDED TO THE
ADJUSTED/ROUNOED TO THE NEAREST \$10,000/\$100,000.

\section{REMARKS}

MAJOR ASSUMPIIONS WHICH haVe bEEN MADE IN THE PREPARATION OF THIS ESTIMATE ARE AS FOLLOHS:

A.) ALl CONSTRUCTION HILL BE PERFORMEO IN A CONTAMINATION FREE ATMOSPHERE.

B.) ALL CONSTRUCTION WORK IS ASSUMEd tO BE PERForMEd BY a fiXed PRICE CONTRACTOR.

C.) OPERATING COSTS ARE NOT INCLUDEO.

D.) dranings and specifications here not available, all quantities, Sizes, etc. here allowances.

E.) CURRENT SCOPE OF NORK ASSUMES THAT THE WASTE VOLUME TO BE TREATED BY FACILITY WILL IHCLUDE MINIMAL AHOUNTS OF CONTAMINATED SOIL. If VOLUMES WERE TO EXCEED ESTIMATES, THE PLANT CAPACITY WOULD NEED TO BE IMCREASEO.

F.) For further comments SEe the detall estimate sheets. 
FLUOR DANIEL NORTHWEST, INC.

COGEMA ENGINEERING

JOB NO. Z649SAA2

FILE MO. Z649SAAZ

SORT

CODE / WBS DESCRIPTION

FDNW FLUOR DANIEL NORTHWEST

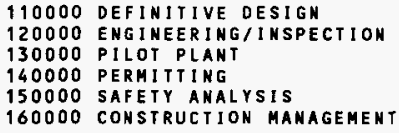

SUBTOTAL 1 ENGINEERING

320001 SITEHORK

320002 STRUCTURES

320003 FIRE PROTECTION \& DETECTION

320004 HVAC

320005 NORMAL ELECTRICAL DISTRIBUTION

320006 STANOBY ELECTRICAL DISTRIBUTION

320007 UNINTERRUPTABLE POWER SOURCE

320008 PROCESS EQUIPMENT DECON ANO REPA

320009 COMPRESSED AIR AMD GAS

320010 PROCESS AIR

320011 RAW HATER \& FIREWATER

320012 DISTRIBUTED CONTROL SYSTEM

320013 COMMUNICATIONS

320014 ANALYTICAL FACILITIES

320016 STACK \& FANHOUSE

320017 HEALTH PHYSICS MONITORING EQUIPM

SUBTOTAL 320 BUILDING

325002 CELL DRAINAGE/COLLECTION

325003 RAD SURVEY EQUIP. FOR WASHED SOL 325004 PROCESS MONITORING INSTR. SYSTEM 325005 AQUEOUS MAKE-UP

325006 BRIDGE CRANES

325008 ROBOTICS

325010 PROCESS VESSEL VEHT

325011 MISC SERVICE PIPIM

325012 MATERIAL HANDLING

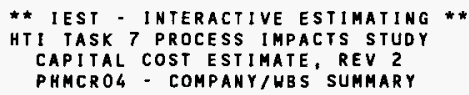

* * IEST - INTERACTIVE ESTIMATING **

HTI TASK 7 PROCESS IMPACTS STUDY

CAPITAL COST ESTIMATE, REV 2

PHMCRO4 - COMPANYIHBS SUMMARY

PAGE 7 OF 14

DATE $02 / 12 / 99 \quad 15: 37: 41$

BY R. OHRT

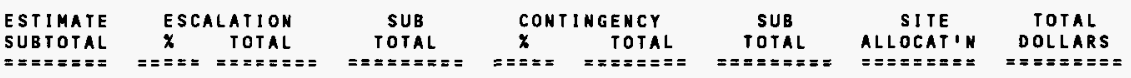

46618102
15539367

15539367
28438322

2496000

19737120

50977052

0.00

0.00

0.00
0.00

0.00

0.00

163805963

0.00

991397

991397
27754710

930702

10603688

4776047

11391309

867557

10483531

285189

296902

442366

15559374

563777

13766581

14440582

2647625

0.00

0.00

0.00
0.00

0.00

0.00

0.00

0.00

0.00

0.00

0.00
0.00

0.00

0.00

0.00

0.00

115801337

0.00

2520101

21236454

2412132

2737558

3096900

22000000

18485871

2236343

20884500
0.00

0.00
0.00

0.00

0.00

0.00

0.00

0.00
0.00
46618102

15539367

28438322

2496000

19737120

50977052

0 163805963

991397

27754710

930702

10603688

4776047

11391309

867557

10483531

285189

296902

442366

15559374

563777

13766581

14440582

2647625

115801337

2520101

21236454

2412132

2737558

2000000

22000000

1848587

2236343
20884500

\section{5 \\ 5438778 \\ 9953412 \\ 873600}

6907992
22939673

62429792

346988

346988
9714148

9714148
325745

325745
3711290

1671616

3986958

303644

3660235

66923

99816
103915

103915

154828

5445780

197321

4818303

5054203

926668

40530467

1260050

10618227

1206066

9368779

1548450

11000000

11000000

9242935

10442250
62934437

20978145

38391734

3369600

26645112

73916725

226235755

1338385

37468858

1256447

14314978

6447663

15378267

1171201

14152766

385005

400817

507194

21005154

761098

18584884

19494785

3574293

156331804

378015

31854681

3618198

4106337

4645350

33000000

27728806

3354514

31326750
13530904

4510301

8254222

724464

5728699

15892095

48640687

7

210126

5882610

197262

2247451

1012283

2414387

183878

2221984

60445

62928

93759

3297809

119492

2917826

3060681

561164

24544093

593483

5001184

568057

644694

5181000

4353422

4353422

526658

4918299

76465349

25488446

46645957

4094064

32373811

89808821

1548512

43351469

1453710

16562430

7459946

17792655

1355080

16374751

445450

463746

690953

24302964

880591
1502711

22555467

4135457

180875898

4373635

36855865

4186255

4751031

5374669

38181000

32082229

3881173 
FLUOR DANIEL NORTHWEST, INC. COGEMA ENGINEERING

JOB NO. Z649SAA2

FILE NO Z649SAAZ

SOR T

CODE/HBS DESCR IPT ION

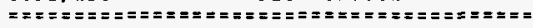

\section{WASH STATION}

325016 DRYER

325018 SHIELDED WASTE COMTAINERS

325019 WASTE RECEIVING AREA

325023 SHREDDER

325024 ACID DIGESTER

325025 ROTARY DRUM FILTER

325026 CENTRIFUGE

325028 EVAPORATOR

325029 GRIMOING MILL

325030 STAGING TANKS

325031 CAT 1 LOADING STATION

325032 CAT 3 CONCRETING/LOADING STATION

325033 JUMPERS

SUBTOTAL 325 SPECIAL EQUIPMENT

SUBTOTAL 32 FIXED PRICE CONSTRUCTIO 257992851

* * IEST - IHTERACTIVE ESTIMATING * *

HI I TASK 7 PROCESS IMPACTS STUDY

CAPITAL COST ESIIMATE, REV 2

PHMCROL - COMPANY/UBS SUMMARY

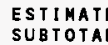

SUB TOTAL
$== \pm===$

ESCALATION
$X$ TOTAL

$=x== \pm== \pm==$

SUB
TOTAL

$== \pm=\boldsymbol{=}=\mathbf{=}$

CONTINGENCY

650550

$675296 \quad 0.00$

13750000

2641421

3991235

3991235

1231200
1717992

1717992
717188

13884750

1944000

1267555

182574

342264

342264
1942463

0.00

0.00

0.00

0.00
0.00

0.00

0.00

0.00

0.00

0.00

0.00

0.00
0.00

162191514

0.00

0.00

$52794500 \quad 0.00$

310787351

0.00

SUBTOTAL 3

CONSTRUCTION

TOTAL FDNW FLUOR DANIEL MORTHUEST

\section{0}

675296
13750000

3750000

2641421

1231200

1231200

1717992
717188

13884750

1944000

1267555

1825749

342264

1942463

142191514

$0 \quad 257992851$

$0 \quad 52794500$

$0 \quad 310787351$

$0 \quad 474593314$
PAGE 8 OF 14

DATE 02/12/99 $15: 37: 41$

BY

R. OHR T
SUB

TOTAL

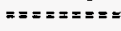
= $=\boldsymbol{=}=\boldsymbol{= \Xi}$

\section{$50 \quad 325275$}

1320710

1320710
1995617

1995617

615600
858990

858996

358594
6042375

6942375

972000

633777

912870

912870

171132
971231

971231

$50 \quad 71095757$

43111626224

$50 \quad 26397250$

$44 \quad 138023474$

42200453267
975825

1012944

20625000

396213

5986852

1846800

2576988

1075782

20827125

2916000

1901332

2738611

513396
2913694

213287271

369619075

79191750

67504658
SITE ALLOCAT'N

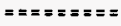

TOTAL DOLLARS

$159032 \quad 1129029$ $3238125 \quad 23863125$

$622054 \quad 4584186$

$939935 \quad 6926788$

$289947 \quad 2136747$

$404587 \quad 2981575$

$168897 \quad 1244679$

$326985 B \quad 24096983$

$457812 \quad 3373812$

$298509 \quad 2199841$

$429962 \quad 3168573$

$80603 \quad 593909$

$457450 \quad 3371144$

$33486101 \quad 246773372$

$58030195 \quad 427649270$

$17224205 \quad 96415955$

$75254400 \quad 524065226$

$123895088 \quad 798941669$

0

$75,046,581$

$200,453,267$

$123,895,088^{798}$

$==$ 
FLUOR DANIEL NORTHUEST, INC.

COGEMA ENGINEERING

JOB NO. Z649SAA2

* I IEST - INTERACTIVE ESTIMATING **

HTI TASK 7 PROCESS IMPACTS STUDY

CAPITAL COST ESTIMATE, REV 2

PHMCROS - CONSTRUCTION MANAGEMENT/OTHER COST SUMMARY
PAGE 9 OF 14

DATE $02 / 12 / 99 \quad 15: 37: 43$

BY R.OHRT
WB S

ESCRIPTION

110000 DEFINITIVE DESIGN

120000 ENGINEER ING/ INSPECTION

130000 PILOT PLANT

140000 PERMITTING

150000 SAFETY ANALYSIS

160000 CONSTRUCTION MANAGEMENT

SUBTOTAL 1 ENGINEERING

320001 SITEHORK

320002 STRUCIURES

320003 FIRE PROTECTION \& DETECTION

320004 HVAC

320005 NORMAL ELECTRICAL DISTRIBUTION

320006 STANDBY ELECTRICAL DISTRIBUTION

320007 UNIHTERRUPTABLE POWER SOURCE

320008 PROCESS EQUIPMENT DECON AND REPAIR

320009 COMPRESSED AIR AND GAS

320010 PROCESS AIR

320011 RAH HATER \& FIREWATER

320012 DISTRIBUTED CONTROL SYSTEM

320013 COMMUNICATIONS

320014 ANALYTICAL FACILITIES

320016 STACK \& FANHOUSE

320017 HEALTH PHYSICS MONITORING EQUIPMENT

SUBTOTAL 320 BUILDING

ES I IMATE

SUBTOTAL

$== \pm==\mathbf{=}$

CONSTRUCTION MANAGEMENT
$x$
TOTAL

$== \pm=$

46618102

15539367

28438322

2496000

19737120

50977052

163805963

991397

27754710

930702

10603688

4776047

11391309

867557

10483531

285189

296902

442366

15559374

563777

1376658

14440582

2647625

115801337

2520101

21236454

2412132

2737558

2000000

1848587

1848587

2236343
20884500

0884500
650550

675296

325014 WASH STATION

325016 DRYER

0.00
TOTAL
$====$

0.00

0.00

0.00

0.00

0.00
0.00

$==\pi=\pi=\begin{array}{r}\text { OTHER } \\ \text { COSTS } \\ 0=0 \\ 0 \\ 0 \\ 0 \\ 0 \\ 0\end{array}$

0.00

0.00

0.00

0.00

0.00

0.00

0.00

0.00

0.00

0.00

0.00

0.00

0.00

0.00

0.00

0.00

SUB
TOTAL
TOTA




$0===$
0
0
0
= = = = = = =

46618102 15539367 28438322 2496000 9737120 5097705

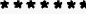

991397 27754710 930702

0603688

4776047

11391309

867557

10483531

285189

296902

442366

15559374

563777

13766581

14440582

2647625

*********

2520101

21236454

2412132

2737558

3096900

22000000

18485871

2236343

20884500

650550

675296

0.00 
FLUOR DANIEL NORTHWEST, INC. COGEMA ENGINEERING

JOB NO, Z649SAA2

FILE HO. Z649SAAZ

WB

ESCR I PTION

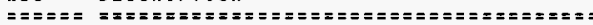

325018 SHIELDED WASTE CONTAINERS

325019 VASTE RECEIVING AREA

325023 SHREODER

325024 ACID DIGESTER

325025 ROTARY DRUM FILTER

325026 CENTRI FUGE

325028 EVAPORATOR

325029 GRINDING MILL

325030 STAGING TANKS

325031 CAT 1 LOADING STATION

325032 CAT 3 CONCRETING/LOADING SIATION

325033 JUMPERS

SUBTOTAL 325

SPECIAL EOUIPMENT

SUBTOTAL 32

FIXED PRICE CONSTRUCTION

\section{PROJECT MANAGEMENT}

SUBTOTAL 3

CONSTRUCTION

PROJECT TOTAL
* IEST - INTERACTIVE ESTIHATIHG * *

HTI TASK 7 PROCESS IMPACTS STUDY

CAPITAL COST ESTIMATE, REV?

PHMCRO5 - CONSTRUCTION MANAGEMENT/OTHER COSI SUMMARY
PAGE 10 OF 14

DATE $02 / 12 / 99 \quad 15: 37: 43$

BY R.OHRT

\begin{tabular}{|c|c|c|c|c|c|}
\hline $\begin{array}{l}\text { ESTIMATE } \\
\text { SUBTOTAL } \\
=======\end{array}$ & $\begin{array}{c}\text { CONSTRUCTION } \\
=====\end{array}$ & $\begin{array}{l}\text { N MANAGEMEMT } \\
\text { TOTAL } \\
========\end{array}$ & $\begin{array}{c}\begin{array}{c}\text { OTHER } \\
\text { COSTS }\end{array} \\
======\end{array}$ & $\begin{array}{c}\text { SUB } \\
\operatorname{rOT} A \mathrm{~L} \\
=======\end{array}$ & $\begin{array}{c}\text { TOT AL } \\
========\end{array}$ \\
\hline $\begin{array}{r}13750000 \\
2641421 \\
3991235 \\
1231200 \\
1717992 \\
717188 \\
13884750 \\
1944000 \\
1267555 \\
1825741 \\
342264 \\
1942463\end{array}$ & $\begin{array}{l}0.00 \\
0.00 \\
0.00 \\
0.00 \\
0.00 \\
0.00 \\
0.00 \\
0.00 \\
0.00 \\
0.00 \\
0.00 \\
0.00\end{array}$ & $\begin{array}{l}0 \\
0 \\
0 \\
0 \\
0 \\
0 \\
0 \\
0 \\
0 \\
0 \\
0 \\
0\end{array}$ & $\begin{array}{l}0 \\
0 \\
0 \\
0 \\
0 \\
0 \\
0 \\
0 \\
0 \\
0 \\
0 \\
0\end{array}$ & $\begin{array}{l}0 \\
0 \\
0 \\
0 \\
0 \\
0 \\
0 \\
0 \\
0 \\
0 \\
0 \\
0\end{array}$ & $\begin{array}{r}13750000 \\
2641421 \\
3991235 \\
1231200 \\
1717992 \\
717188 \\
13884750 \\
1944000 \\
1267555 \\
1825741 \\
342264 \\
1942463\end{array}$ \\
\hline 142191514 & & 0 & 0 & 0 & $* * * * * * * *$ \\
\hline 257992851 & & 0 & 0 & 0 & $* * * * * * * *$ \\
\hline 52794500 & 0.00 & 0 & 0 & 0 & 52794500 \\
\hline 310787351 & & 0 & 0 & 0 & ********* \\
\hline
\end{tabular}


FLUOR DANIEL NORTHHEST, INC.

COGEMA ENGINEERING

JOB NO. 2649SAA2

FILE NO. 2649SAA2

WBS OESCR IPTION

110000 DEFINITIVE DESIGN

120000 ENGINEERING/INSPECTION

130000 PILOT PLANT

140000 PERMITTING

150000 SAFEIY AHALYSIS

160000 CONSTRUCTION MANAGEMENT

SUBTOTAL 1 ENGINEERING

320001 SITEWORK

320002 STRUCTURES

320003 FIRE PROTECTION \& DETECTION

320004 HVAC

320005 NORMAL ELECTRICAL DISTRIBUTION

320006 STANDBY ELECTRICAL DISTRIBUTIOM

320007 UNINTERRUPTABLE POWER SOURCE

320008 PROCESS EQUIPMENT DECON ANO REPAIR

320009 COMPRESSED AIR AMD GAS

320010 PROCESS AIR

320011 RAW WATER \&IREWATER

320012 DISTRIBUTED CONTROL SYSTEM

320013 COMMUNICATIONS

320014 ANALYTICAL FACILITIES

320016 STACK \& FAHHOUSE

320017 HEALTH PHYSICS MONITORING EQUIPMENT

SUBTOTAL 320 BUILDING

325002 CELL ORAINAGE/COLLECTION

325003 RAD SURVEY EQUIP. FOR WASHED SOLIDS

325004 PROCESS MONITORING INSTR. SYSTEM

325005 AOUEOUS MAKE-UP

325006 BRIDGE CRAHES

325008 ROBOTICS

325010 PROCESS VESSEL VENT

325011 MISC SERVICE PIPING

325012 MATERIAL HANDLING

325014 WASH STATION

325016 DRYER
* * IEST - INTERACTIVE ESTIMATING * *

HII TASK 7 PROCESS IMPACTS STUOY

CAPITAL COST ESTIMATE, REV 2

PHMCROG - SITE ALLOCATIONS BY WBS
PAGE 11 OF 14

DATE $02 / 12 / 99 \quad 15: 37: 24$

BY R.OHRT

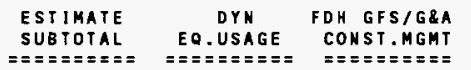

46618102

15539367

28438322

2496000

50977052

163805963

991397

27754710

930702

10603688

4776047

11391309

867557

10483531

285189

296902

442366

15559374

563777

1376658

14440582

2647625

115801337

2520101

21236454

2412132

2737558

3096900

22000000

18485871

223634

20884500

650550
675296

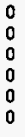

0

0
0
0

0

0
0
0

(

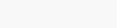
FDH MPR FDH GFS/GEA FDH MPR/G\&A SITE ALLOC

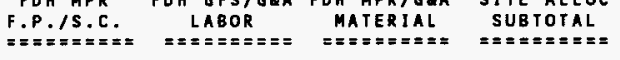

$$
\begin{array}{r}
10022891 \\
3340963 \\
6114239 \\
536640 \\
4243480 \\
10960066 \\
35218282
\end{array}
$$

155649

4357489

146120

1664779

749839

1788435

136206

1645914

44774

46613

69451

2442821
88512

2161353

2267171

415677

18180809

18180809

0

395655

3334123

378704

429796

486213

3454000

2902281

351105

3278866

102136
106021

278866
102136

106021

106021 
FLUOR DANIEL NORTHWEST, INC.

COGEMA ENGINEERING

JOB HO. 2649SAA2

* IEST - INTERACTIVE ESTIMATING *

HTI TASK 7 PROCESS IMPACTS STUOY

CAPITAL COST ESTIMATE REY?

PHMCROG - SITE ALLOCATIONS BY WBS
PAGE 12 OF 14

OATE $02 / 12 / 99 \quad 15: 37: 24$

BY R.OHRT

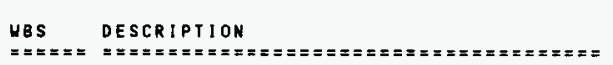

325018 SHIELDED WASTE CONTAINERS

325019 WASTE RECEIVING AREA

325023 SHREDDER

325024 ACID DIGESTER

325025 ROTARY DRUM FILTER

325026 CENTRIFUGE

325028 EVAPORATOR

325029 GRINOING MILL

325030 STAGING TANKS

325031 CAT 1 LOADING STATION

325032 CAT 3 CONCRETING/LOADING STATION

325033 JUMPERS

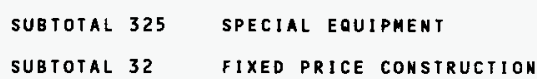

340000 PROJECT MANAGEMENT

SUBTOTAL 3

CONSTRUCTION
ESTIMATE

SUBTOTAL

$==\mathbf{=}=\mathbf{=}=\mathbf{=}=$

13750000

2641421

3991235

1231200

1231200

717992
717188

13884750

1944000

1267555

1825741

342264

1942463

\section{DYN EQ.USAGE}

FDH GFS/G\&A CONST. MGMT = = = = = $=$ = = =

$=\mathbf{=}=\mathbf{=}=\mathbf{=}=$

FDH MPR F.P./S.C.

= $=\boldsymbol{=}=\boldsymbol{=}=\mathbf{=}=$

FDH

FDH GFS
$=\approx A B O R$
LABOR

2158750

414703
626623

193298

269724

112598

2179905

305208

199006

286641

286641
53735

304966

142191514

22324067

40504877

$52794500 \quad 131986$

310787351

131986

0

0

$\begin{array}{rr}0 & 11350817\end{array}$

PROJECT TOTAL

$474,593,314$
0

\section{FOH MPR/G\&A MATERIAL}

$= \pm=$

SITE ALLOC
SUBTOTAL

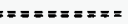

2158750

414703

626623

193298

269724

112598

2179905

305208

199006

286641

53735

304966

22324067

40504877

11482803

51987681

$87,205,963$ 
FLUOR DANIEL NORTHUEST, INC. COGEMA ENGINEERING JOB NO. 2649 SAA2

FILE NO. 2649SAA2
* * IEST - InTERACTIVE ESTIMATING * *

HTI TASK 7 PROCESS IMPACTS STUDY

CAPITAL COST ESTIMATE, REV 2
PAGE

DATE
$130 F 14$

$02 / 12 / 99 \quad 15: 37: 45$ R. OHR T

PHMCRO 7 - SITE ALLOCATION ESCALATION/CONTIMGENCY REPORT

\begin{tabular}{|c|c|c|c|}
\hline $\begin{array}{l}\text { ITE ALLOC } \\
\text { SUB TOTAL } \\
========\end{array}$ & $\begin{array}{l}\text { ESCI } \\
X \\
== \pm==\end{array}$ & $\begin{array}{l}\text { ALATION } \\
\text { IOTAL } \\
=======\end{array}$ & $\begin{array}{c}\text { sUB } \\
\text { TOTAL } \\
========\end{array}$ \\
\hline $\begin{array}{r}10022891 \\
3340963 \\
6114239 \\
536640 \\
4243480 \\
10960066\end{array}$ & $\begin{array}{l}0.00 \\
0.00 \\
0.00 \\
0.00 \\
0.00 \\
0.00\end{array}$ & $\begin{array}{l}0 \\
0 \\
0 \\
0 \\
0 \\
0\end{array}$ & $\begin{array}{r}10022891 \\
3340963 \\
6114239 \\
536640 \\
4243480 \\
10960066\end{array}$ \\
\hline 35218282 & 0.00 & 0 & 35218282 \\
\hline
\end{tabular}

$==\begin{array}{rr}\begin{array}{c}\text { CONT INGENCY } \\ \text { TOTAL }\end{array}= \\ ===== \pm== \\ 35 & 3508012 \\ 35 & 1169337 \\ 35 & 2139983 \\ 35 & 187824 \\ 35 & 1485218 \\ 45 & 4932029 \\ 38 & 13422405\end{array}$

TOTAL

DOLLARS

WBS OESCRIPTION

110000 DEFINITIVE DESIGN

120000 ENGINEERING/INSPECTIOH

130000 PILOT PLANT

140000 PERMITTING

150000 SAFETY ANALYSIS

160000 CONSTRUCTION MANAGEMENT

SUBTOTAL 1 ENGINEERING

155649

4357489

146120

1664779

1664779
749839

1788435

136206

1645914

44774

46613

46613
69451

2442821

88512

2161353

226717

415677

0.00

320014 AHALYTICAL FACIL

320017 HEALTH PHYSICS MONITORIHG EQUIPMENT

18180809

SUBTOTAL 320 BUILDING

395655

3334123

378704

429796

486213

3454000

2902281

351105
3278866

102136

102136
106021

325011 MISC SERVICE PIPI

325014 WASH STATION

325016 DRYER

0.00

0.00

0.00

0.00
0.00

0.00
0.00

0.00

0.00

0.00

0.00

0.00

0.00

0.00
0.00

0.00

0.00

0.00

0.00
0.00

0.00

0.00

0.00

0.00

0.00

0.00

0.00
155649

4357489

146120

1664779

749839

1788435

136206

1645914

44774

46613

244282

4.

2161353

2161353

2267171
415677

18180809

395655

3334123

378704

429796

486213

3454000

2902281

351105

3278866

102136

106021
54477

1525121

51142

582672

262443

625952
47672

576070

15671

16314

24308

854987

30979

756473

793509

145487

6363283

0.00
0.00

197827

1667061

189352

214898
243106

1727000

1451140

175552

1639433

$\begin{array}{r}51068 \\ \hline\end{array}$

53010

13530904

4510301

8254222

724464

5728699

15892095

48640687

210126

5882610

197262

2247451

1012283

2414387

183878

2221984

60445

62928

93759

3297809

119492

2917826

3060681

561164

24544093

593483

5001184

568057

644694

729319

5181000

4353422

526658

4918299

4918299
153204

159032 
FLUOR DANIEL NORTHWEST, INC.

COGEMA ENGINEERING

JOB NO. 2649SAA2

FILE NO. 2649SAA2

WBS DESCRIPTION

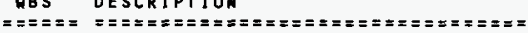

325018 SHIELDEO WASTE CONTAINERS

325019 WASTE RECEIVING AREA

325023 SHREDDER

325024 ACID DIGESIER

325025 ROTARY DRUM FILTER

325026 CENTRIFUGE

325028 EVAPORATOR

325029 GRINDING MILL

325030 STAGING TANKS

325031 CAT 1 LOAOING STATION

325032 CAT 3 CONCRETING/LOADIMG STATION

325033 JUMPERS

SUBTOTAL 325 SPECIAL EQUIPMENT

SUBTOTAL 32 FIXED PRICE CONSTRUCTION

\section{PROJECT MANAGEMEN}

SUBTOTAL 3 CONSTRUCTION

PROJECT TOTAL
* * IEST - INTERACTIVE ESTIMATING * *

HTI TASK 7 PROCESS IMPACTS STUDY

CAPITAL COST ESTIMATE, REV 2

PHMCRO7 - SITE ALLOCATION ESCALATION/CONTINGENCY REPORT
PAGE 14 OF 14

DATE $02 / 12 / 99 \quad 15: 37: 45$

BY

\begin{tabular}{|c|c|c|c|c|c|c|}
\hline $\begin{array}{l}\text { SITE ALLOC } \\
\text { SUBTOTAL } \\
========\end{array}$ & $== \pm==$ & $\begin{array}{l}\text { LATION } \\
\text { TOTAL } \\
=======\end{array}$ & $\begin{array}{c}\text { SUB } \\
\text { TOTAL } \\
===\approx=\approx==\end{array}$ & $=\stackrel{\operatorname{con} \gamma}{x}=$ & $\begin{array}{l}\text { INGENCY } \\
\text { TOTAL } \\
=\approx==\approx===\end{array}$ & $\begin{array}{c}\text { TOTAL } \\
\text { DOLLARS } \\
=\approx \equiv=\approx \pi \equiv==\end{array}$ \\
\hline $\begin{array}{r}2158750 \\
414703 \\
626623 \\
193298 \\
269724 \\
112598 \\
2179905 \\
305208 \\
199006 \\
286641 \\
53735 \\
304966\end{array}$ & $\begin{array}{l}0.00 \\
0.00 \\
0.00 \\
0.00 \\
0.00 \\
0.00 \\
0.00 \\
0.00 \\
0.00 \\
0.00 \\
0.00 \\
0.00\end{array}$ & $\begin{array}{l}0 \\
0 \\
0 \\
0 \\
0 \\
0 \\
0 \\
0 \\
0 \\
0 \\
0 \\
0\end{array}$ & $\begin{array}{r}2158750 \\
414703 \\
626623 \\
193298 \\
269724 \\
112598 \\
2179905 \\
305208 \\
199006 \\
286641 \\
53735 \\
304966\end{array}$ & $\begin{array}{l}50 \\
50 \\
50 \\
50 \\
50 \\
50 \\
50 \\
50 \\
50 \\
50 \\
50 \\
50\end{array}$ & $\begin{array}{r}1079375 \\
207351 \\
313311 \\
96649 \\
134862 \\
56299 \\
1089952 \\
152604 \\
99503 \\
143320 \\
26867 \\
152483\end{array}$ & $\begin{array}{r}3238125 \\
622054 \\
939935 \\
289947 \\
404587 \\
168897 \\
3269858 \\
457812 \\
298509 \\
429962 \\
80603 \\
457450\end{array}$ \\
\hline 22324067 & 0.00 & 0 & 22324067 & 50 & 11162033 & 33486101 \\
\hline 40504877 & 0.00 & 0 & 40504877 & 43 & 17525317 & 58030195 \\
\hline 11482803 & 0.00 & 0 & 11482803 & 50 & 5741401 & 17224205 \\
\hline 51987681 & 0.00 & 0 & 51987681 & 45 & 23266719 & 75254400 \\
\hline 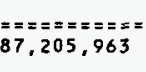 & & $0=$ & 058 & $\begin{array}{l}==5 \\
42\end{array}$ & 689 & $\begin{array}{l}======== \\
3,895,088\end{array}$ \\
\hline
\end{tabular}


* IEST - INTERACTIVE ESTIMATING *

HTI TASK 7 PROCESS IMPACTS STUDY

CAPITAL COST ESTIMATE, REV 2

FILE HO. Z649SAA2

PHMCROS - ESTIMATE DETAIL BY WBS/ COST CODE

COST EQUIP

CODE OUANTITY MAHHOURS LABOR USAGE

OESCR IPTION

NUMBER

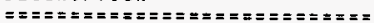

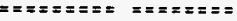

MATERIAL

SUB -

PAGE

DATE $02 / 12 / 99 \quad 15: 37: 47$

BY R.OHRT

\section{0 \\ DEFINITIVE OESIGN}

110000.00

110000.0000100 ENGINEERING

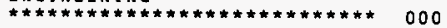
DEF INITIVE DESIGN

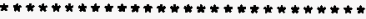

AT $15 x$ OF HBS 3

SUBTOTAL

ENGINEERING

TOTAL

\section{COST CODE 00000}

WBS 110000

(ESCALATION

$0.00 \%$ - CONTINGEMCY

TOTAL WBS 110000 DEFINITIVE DESIGN

$46,618,102$

0

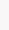

I LS $748044 \quad 46618102$

$0 \quad 46618102$

748,044
$46,618,102$
$35,00 \ldots, 044$
$46,618,102$

0

0

0

0

$46,618,102$

0

$46,618,102$

$46,618,102$ 


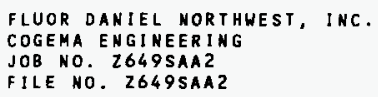

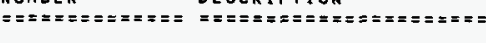

120000 ENGINEER ING/INSPECTION

120000.00 ENGINEERING

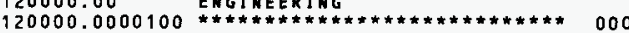
ENGINEERING/INSPECTION

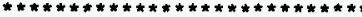
AT $5 \%$ of WBS 3

SUBTOTAL ENGINEERING

TOTAL COST CODE OOOOO

WBS 120000

CESCALAIION

$0.00 \%$ - CONTINGEHCY
$==\Sigma=== \pm=== \pm====$

$\operatorname{LABOR}$
EQUIP. OH\&P TOTAL MENT I B I DOLLARS

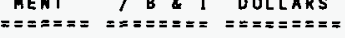

0

(1)

$0 \quad 15539367$ 


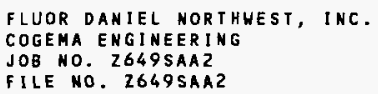

\section{ACCOUNT \\ NUMB E R \\ DESCRIPTION}

COST EQUIP

CODE QUANTITY MANHOURS LABOR USAGE

USAGE
$=\approx \approx=2$

SUB

\section{0 PILOT PLAHT}

130000.00 ENG INEER ING

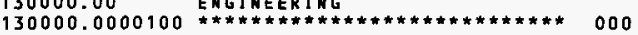
P I L OT PLANT
$* * * * * * * * * * * * * * * * * * * * * * * * * * * *$

130000.0000102 USE $20 \%$ OF WBS 325

SUBTOTAL ENGINEERING

TOTAL

COST CODE OODOO

WBS 130000

(ESCALATION

$0.00 \%$ - CONTINGENCY $35.00 \%$ )

0

0

000

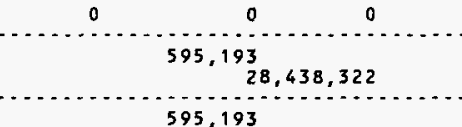

595,193

$28,438,322$

0

0

$0 \quad 0$

0

0

$28,438,322$

-

0

$0 . . . .$.

$028,438,322$

TOTAL WBS 130000 PILOT PLANT

595,193

$28,438,322$
0

0

0

$28,438,322$ 


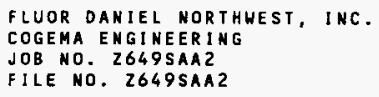

\section{ACCOUNT}

NUMBER

OESCRIPTIOH

COST EQUIP

CODE OUANTITY MANHOURS LABOR USAGE

SUB-
MATERIAL CONTRACT

PAGE 4

DATE $02 / 12 / 99 \quad 15: 37: 47$

BY R, OHRT

\section{0 PERMITIING}

140000.00 ENGINEERING

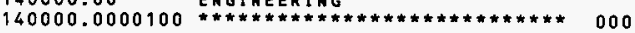
PERMITIIING $* * * * * * * * * * * * * * * * * * * * * * * * * * * *$

140000.0000102 PRODUCE RCRA PART B PERMIT, ASSUME 20 MAMYEAR OF LABOR

\section{SUBTOTAL ENGINEERING}

TOTAL

COST CODE 00000

HBS 140000

(ESCALATION

$0.00 \%$ - CONTINGENCY

\section{0}

000

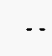

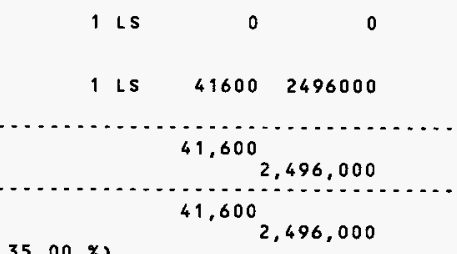

.

0

0

0

0

0

0

0

0

2496000

0

0

D

0

$2,496,000$

0

0

$2,496,000$

TOTAL WBS 140000 PERMITTING

41,600

$2,496,000$
0
0
$2,496,000$ 
FLUOR DANIEL NORIHUEST, INC.

COGEMA ENGINEER ING

JOB NO. $2649 \$$ SAL2

* * IEST - INTERACTIVE ESTIMATING * *

HTI TASK 7 PROCESS IMPACTS STUDY

CAPIIAL COST ESTIMATE, REV?

PHMCRO8 - ESTIMATE DETAIL BY UBS / COST CODE

PAGE DATE

BY

$02 / 12 / 99 \quad 15: 37: 47$

R. OHR T

\section{ACCOUN}

DESCR I P I I ON

SAFETY AHALYSIS

150000

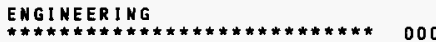

150000.00

SAFETY ANALYSIS

***************************0)

150000.0000102 ASSUME 50 MANYEAR OF LABOR

SUBTOTAL ENGINEERING

TOTAL

COST CODE 00000

WBS 150000

(ESCALATION

$0.00 X-$ CONTINGENCY

$35.00 \%$

TOTAL WBS 150000 SAFETY ANALYSIS
EQUIP

CODE QUANTITY MANHOURS LABOR USAGE SUB -
MATERIAL CONTRACT

$==\approx====$

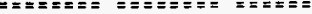

00

000

$104000 \quad 9868560$

0

0

0

208,000

$19,737,120$

0

208,000

0

-...........

o

0

EQUIP.

MENT

OH\&P TOIAL

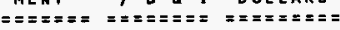

$19,737,120$

0

208,000

$19,737,120$
0
0

09868560

$0 \quad 9868560$

$19,737,120$

$19,737,120$

(

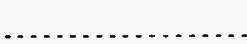
${ }^{0} 19,737,120$ 
FLUOR DANIEL NORTHWEST, INC.

COGEMA ENGINEERING

JOB NO. 2649 SAA2

HTI TASK 7 PROCESS IMPACTS STUDY

CAPITAL COSTESTIMATE, REV 2

PHMCROB - ESTIMATE DETAIL BY WBS, COST CODE
* * IEST - INTERACTIVE ESTIMAIING *

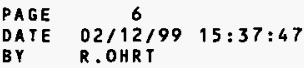

COST EQUIP

CODE OUANTITY MANHOURS LABOR USAGE

EQUIP - $\quad$ OH\&P

TOTAL

ACCOUNT

DESCRIPTION

$======+2$

MANHOUR

LABOR USAGE MATERIAL CONTRACT

C $====2 \& 1$ DOLLARS

160000

CONSTRUCTION MANAGEMENT

160000.20 CONSTRUCTION MANAGEMENT

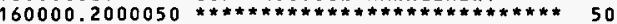
CONSTRUCTION MANAGEMENT ${ }_{* * * * * * * * * * * * * * * * * * * * * * * * * * * * t}$

160000.2000100 CONSTRUCTION MANAGEMENT, AT $18.75 \%$ OF CONSTRUCTION (WBS 32) AND INCLUDES COSTS FOR BID PACKAGE PREPARATION,

160000.2000101 CONTRACT MANAGEMENT \& MANAGEMENT \& PLANHING SUPPORT .

SUBTOTAL CONSTRUCTION MANAGEMENT

TOTAL COST CODE 50120 HBS 160000 (ESCALATION

$0.00 \%$ - CONTINGENCY 501

501 o

$1 \mathrm{LS}$

68554450977052

0

0

0

o

0

0

0

685,544
$50,977,052$
$45,00 \ldots 8,544$
$50,977,052$

0

0

0

$50,977,052$

$50,977,052$
685,544

$50,977,052$
0 (n)

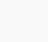

0

-

0
${ }^{0} 50,977,052$ 
FLUOR DANIEL NORTHHEST, INC.

COGEMA ENGINEERING

JOB NO. Z649SAAZ

* IEST - INTERACTIVE ESTIMATING *

HTI TASK 7 PROCESS IMPACTS STUDY

CAPITAL COST ESTIMATE, REV ?

FILE HO. Z649SAAZ

PHMCR 08

ESTIMATE DETAIL BY WBS, COST CODE

ACCOUNT

DESCRIPTION

$\cos T$

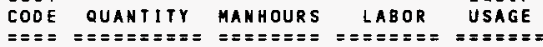

SITEHORK

320001

SITEWORK

320001.02

320001.0200100 SIIEHORK COST FOR

CLEAR AND GRUB.

320001.0200110 LEVEL SITE, ASSUME MOVE AN

AVERAGE OF 18 ", COMPACT,

INCLUDES WATER TRUCK.

320001.0200120 PAVING AMD ROADS

320001.0200130 SITEHORK COST FOR LIGHTING, 50

ALLOWANCE.

320001.0200140 SITEHORK COST FOR UTILIIIES, 501 ALLOHANCE.

\section{SUBTOTAL SITEWORK}

SALES TAX $8.00 \%$

OH\&P (ON MARKUPS ONLY)

TOTAL

\section{COST CODE 50102 \\ YBS 320001}

(ESCALATION

$0.00 X-$ CONTINGENCY

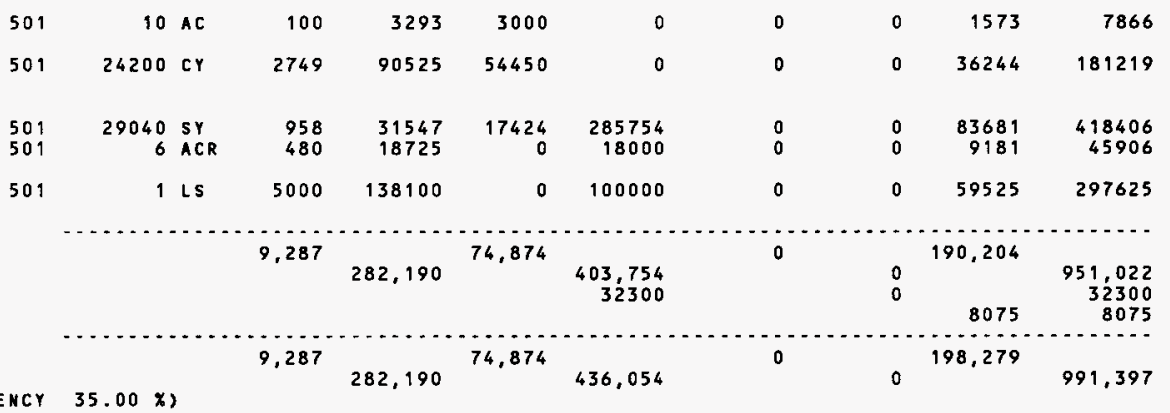

TOTAL HBS 320001 SITENORK

9,287

74,874

436,054

0 $\begin{array}{lll}\text { PAGE } & 7 \\ \text { DATE } & 02 / 12 / 99 & 15: 37: 47\end{array}$

BY R.OHRT

282,190

SUB -

EQUIP- OH\&P TOTAL

MENT I B \& I DOLLARS 
FLUOR DANIEL NORTHHEST, INC.

COGEMA ENGINEERING

JOB HO. Z649SAAZ

FILE NO, Z649SAA2

\section{ACCOUNT}

NUMBER

DESCR I PI I ON

STRUCTURES

320002

320002.02

SITEWORK

320002.0200100 EXCAVATE AND BACKFILL FOR BUILDING, ASSUMES 20,000 CY.

SUB TOTAL

SITEHORK

IOTAL

COST CODE 50102

HBS 320002

$0.00 \%$ - CONTIHGENCY $35.00 \%$
* * IEST - INTERACIIVE ESTIMAIING *

HTI TASK 7 PROCESS I MPACTS STUDY

CAPITAL COST ESTIMATE, REV 2

PHMCROB - ESTIMATE DETAIL BY WBS / COST CODE

COST OUANTITY MANHOURS LABOR USAGE MATERIAL CONTRACT
CODE

$$
\begin{aligned}
& \begin{array}{lcc}
\text { PAGE } & \text { B } \\
\text { DATE } & 02 / 12 / 99 & 15: 37: 47
\end{array} \\
& \text { BY R.OHRT }
\end{aligned}
$$

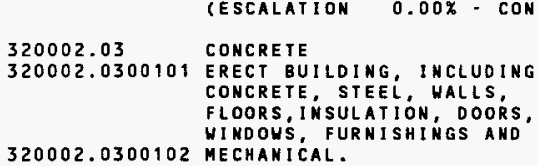

\section{SUBTOTAL COHCRETE}

SALES TAX $8.00 \%$ OH\&P (ON MARKUPS ONLY)

TOTAL

\section{COST CODE 50103}

WBS 320002

(ESCALATION

0.00X - CONTIHGENCY

501

\section{1 \\ $140000 \mathrm{SF}$}

$$
0
$$

0

0

0

0

373,800

$13,725,936$

0

$7,735,000$

618800

373,800

$13,725,936$

0

$8,353,800$

$35.00 \times)$
EQUIP - OH\&P TOTAL MENT I B \& I DOLLARS

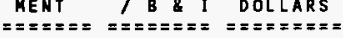

\section{TOTAL WBS 320002 STRUCTURES}

376,200

$13,804,968$

45,00

$8,353,800$
0

$0^{5,550,942}$ 


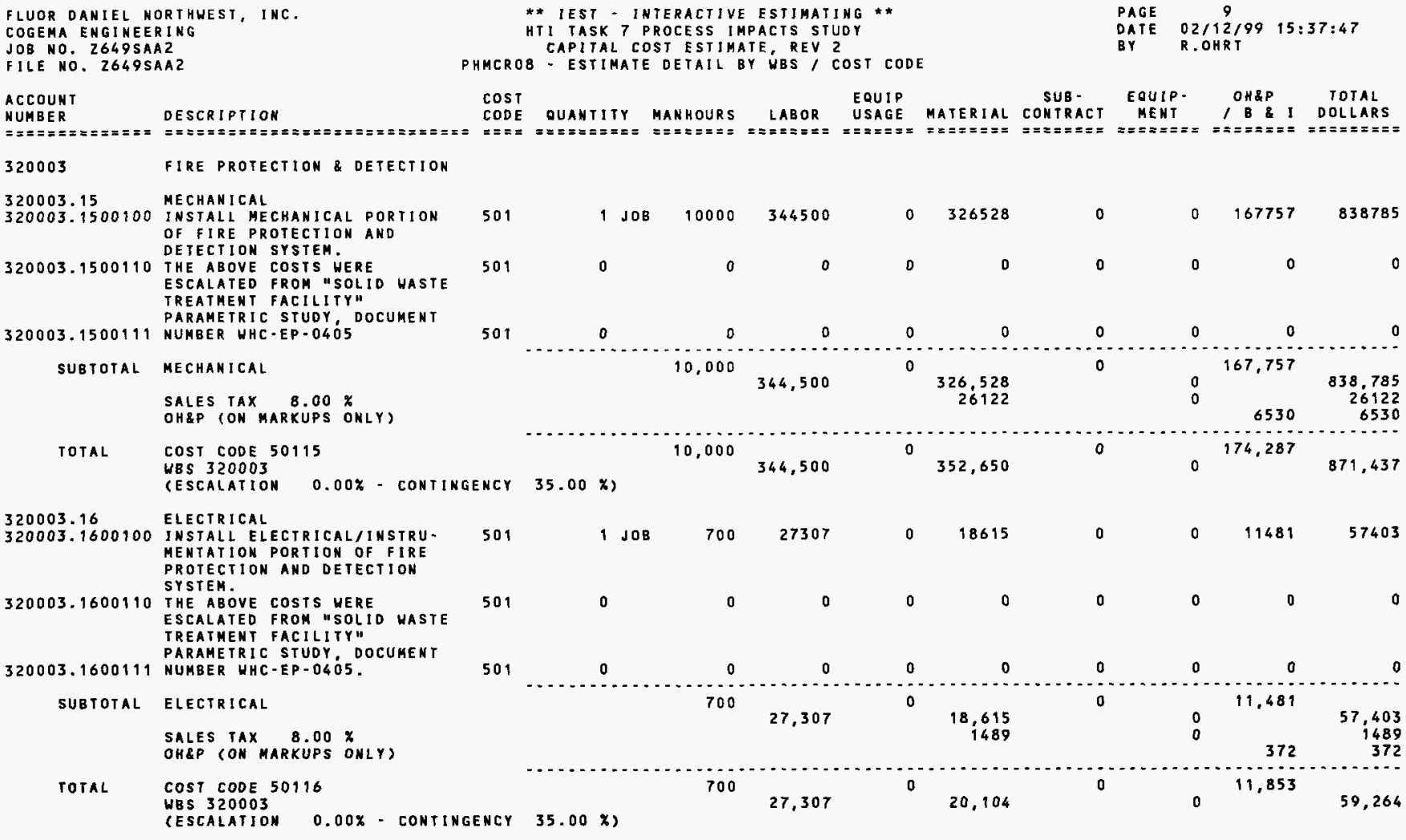

TOTAL WBS 320003 FIRE PROTECTION \& DETECTION

10,700

371,807
372,754
186,140

0

930,702 
FLUOR DANIEL NORTHUEST, INC. COGEMA ENGINEERING

JOB NO. 2649SAA2

FILE NO. Z649SAA?

\begin{abstract}
ACCOUNT
NUMBER

DESCRIPT ION

$\boldsymbol{=}=\boldsymbol{=}=\mathbf{=}=$

HVAC

320004

320004.15 MECHANICAL

320004,1500100 INSTALL MECHANICAL PORTION OF HVAC - DUCT, EQUIPMENT PIPING \& VALVEŚ

320004.1500110 THE ABOVE COSTS WERE ESCALATED FROM "SOLID WASTE
TREATMENT FACILITY"
PARAMETRIC STUDY, DOCUMENT ESCALATED FROM "SOLID WASTE
TREATMENT FACILITY"
PARAMETRIC STUDY, DOCUMENT ESCALATED FROM ISOLID WAST
TREATMENT FACILITY"
PARAMETRIC STUOY, DOCUMENT 320004.1500111 NUMBER WHC-EP-0405, THEN SINGLE FLODR INSTEAD OF A 2 SIORY LAYOUT.
\end{abstract}

\section{SUBTOTAL MECHANICAL}

SALES TAX $8.00 \%$ OHEP (ON MARKUPS ONLY)

TOTAL

COST CODE 50115

HBS 320004

(ESCALATION $0.00 \%$ - CONTINGENCY $35.00 \%$ )
* * IEST - INTERACTIVE ESTIMATING * *

HTI TASK 7 PROCESS IMPACTS STUDY

CAPITAL COST ESTIMATE, REV 2

PHMCROB - ESTIMATE DETAIL BY WBS / COST CODE
PAGE 10

DATE $02 / 12 / 99 \quad 15: 37: 47$

BY

COST UUATITY MANHOURS EQUIP SUB- EQUIP- OH\&P TOTAL

CODE QUANTITY MANHOURS LABOR USAGE MATERIAL

$320004.16 \quad$ ELECTRICAL

320004.1600100 INSTALL ELECTRICAL/INSTRUMENTATION PORTION OF THE HVAC SYSTEM.

320004.1600110 THE ABOVE COSTS WERE

ESCALATED FROM "SOLID WASTE

501

$140000 \mathrm{SF}$

3456688 TREATMENT FACILITY"

PARAMETRIC STUDY, DOCUMENT

320004.1600111 NUMBER UHC-EP-040́5, THEN REDUCED BY HALF TO'REFLECT SIHGLE FLOOR INSTEAD OF A 2 STORY LAYOUT.

SUBTOTAL ELECTRICAL

SALES TAX $8.00 \%$ OHEP (ON MARKUPS ONLY)

TOTAL

$$
\begin{aligned}
& \text { COST CODE } 50116 \\
& \text { UBS } 320004
\end{aligned}
$$

501

0

0

0

0

0

0

o

o

$6,727,000$
224000

501

o

0

0

0

o

0

0

0

35,000

$1,365,350$

0

$1,400,000$
112000

35,000

$1,365,350$
0

$1,512,000$

(n)

0

$(0$

0

691,338 $28000 \quad 28000$ 
FLUOR DANIEL NORTHWEST, INC.

COGEMA ENGINEERING

JOB NO. 2649SAA2

* * IEST - INTERACTIVE ESTIMATING * *

KTI TASK 7 PROCESS IMPACTS STUDY

CAPITAL COST ESTIMATE, REV 2

PHMCRO8 - ESTIMATE DETAIL BY HBS/ COST CODE

$\cos T$

ACCOUNT

DESCRIPTION

CODE QUANTITY MANHOURS LABOR USAGE

$===\mathbf{=}=\mathbf{=}=\mathbf{=}$

$0.00 \%$
GESCALATION
$35.00 \times)$
PAGE 11

DATE 02/12/99 15:37:47

BY R.OHRT

SUB MATERIAL CONTRACT

EQUIP- OH\&P TOTAL MENT $\quad$ B \& I DOLLARS

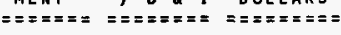

105,000

$$
3,946,950
$$

0

$4,536,000$
0
$0^{2,120,738}, 0,603,688$ 


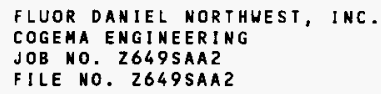

PAGE 12

DATE $02 / 12 / 99 \quad 15: 37: 47$

BY R.OHRT

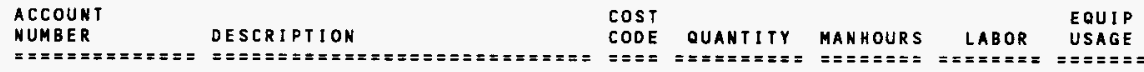

SUB-
MATERIAL CONTRAC

EQUIP- OH\&P TOTAL

NUMBER

NORMAL ELECTRICAL DISTRIBUTION

320005

ELECTRICAL

320005.16

320005.1600050 NORMAL ELECTRICAL DISTRIBU-

TION EQUIPMENT, INCLUDES

$501 \quad 140000$ SF

0

$= \pm====+==+==+$

MCC'S TRANSFORMERS SHITCH-

320005.1600100 INSTALL NORMAL ELECTRICAL

DISTRIBUTION SYSTEM.

140000 SF

$44996 \quad 1755294$

$0 \quad 1020040$

$0 \quad 255010$

1275050

320005,1600110 THE ABOVE COSTS UERE

ESCALATED FROM "SOLID WASTE

TREATMENT FACILITY"

PARAMETRIC STUDY, DOCUMENT

320005.1600111 NUMBER WHC-EP-040́5.

SUBTOTAL

\section{ELECTRICAL}

SALES TAX $8.00 \%$

OH\&P (ON MARKUPS ONLY)

TOTAL

COST CODE 50196

WBS 320005

CESCALATION $0.00 \%$ - CONTINGENCY $35.00 \%$

(ESCALATIOH $0.00 \%$ - CONTINGENCY $35.00 \%$ )

o

$0 \quad 892500$

0

661949

3309743

501

0 o 0

0

0

00

0

501

0
44,996
$4.755,294$

0

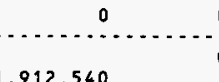

12,540
153003

916,959

$\begin{array}{rrrr}0 & 916,959 & \\ 0 & & 4,584,793 \\ & & & 153003 \\ & & 38250 & 38250\end{array}$

44,996

$\begin{array}{ll}1,755,294 & 0 \\ 2,065,543\end{array}$

955,209

o

o

$4,776,047$

TOTAL WBS 320005 NORMAL ELECTRICAL DISTRIBUTION

44,996

$1,755,294$

0

$2,065,543$

o
955,209

$4,776,047$ 
PAGE 13

DATE $02 / 12 / 99 \quad 15: 37: 47$

BY R.OHRT

EQUIP

CODE QUANTITY MANHOURS LABOR USAGE

DESCRIPTION

SUB.

SUB-
CONTRACT

EQUIP. OH\&P TOTAL

ACCOUNT

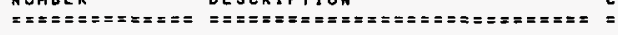

320006

STANDBY ELECTRICAL DISTRIBUTION

$320006.16 \quad$ ELECTRICAL

320006.1600050 STANDBY ELECTRICAL DISTRIBU- S01

TI ON EQUIPMENT, I HCLUDES

TI ON EQUIPMENT, I HCLUDES
STANDBY GENERATORS, MCC'S

SHITCHGEAR, LOAD CIRS, ETC.

320006.1600100 INSTALL STANDBY ELECTRICAL

DISTRIBUTION SYSTEH.

320006.1600110 THE ABOVE COSTS WERE

ESCALATED FROM "SOLID WASTE

TREATMENT FACILITY"

PARAMETRIC STUDY, DOCUMENT

320006.1600111 NUMBER WHC-EP-040́5

SUBTOTAL

ELECTR ICAL

SALES TAX 8.00\%

OH\&P (ON MARKUPS ONLY)

TOTAL

COST CODE 50116

NBS 320006

CESCALATION

$0.00 \%$ - CONTINGENCY $35.00 \%$ )

$1 \mathrm{LS}$

0

0

08032500

$0 \quad 2008125$

10040625

501

1 JOB

6200

241862

$0 \quad 181560$

o

0

105856

529278

501

0

0

0

0

0

0

$2,113,981$

6,200

241,862

$8,214,060$

657124

0

0

164281

$10,569,903$

657124 164281

6,200

241,862

0

871,184

o

$2,278,262$

6,200

241,862
$0_{8,871,184}$

0

0
$2,278,262$ 


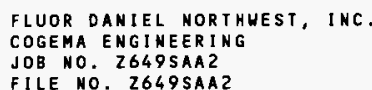

\section{ACCOUNT}

NUMBER DESCRIPTION

COST EQUIP

CODE QUANTITY MANHOURS LABOR USAGE

SUB- EQUIP- OH\&P, TOTAL
MATERIAL COHTRACT

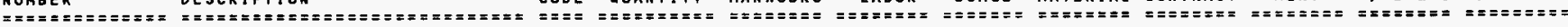

320007

UNINTERRUPTABLE POWER SOURCE

320007.16 ELECTRICAL

320007.1600100 INSTALL UNINTERRUPTABLE

POWER SUPPLY SYSTEM.

320007.1600110 THE ABOVE COSTS HERE

ESCALATED FROM "SOLID HASTE

TREATMENT FACILITY"

PARAMETRIC STUDY, DOCUMENT

320007.1600111 NUMBER WHC-EP-0405.

SUBTOTAL ELECTRICAL

SALES TAX $8.00 \%$

OH\&P (ON MARKUPS ONLY)

TOTAL

COST CODE 50116
HES 320007

$0.00 \%$ - CONTINGENCY $35.00 \%$ )

$1 \mathrm{JOB}$

1600

62416

501

o

0

o

$0 \quad 584842$

0

0

0

o 161815

809073

501

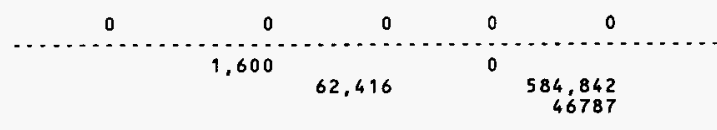

1,600

62,416

0

631,629

0

0

0

0

161,815

815

(ESCALATION

TOTAL WBS 320007 UNINTERRUPTABLE POWER SOURCE $11696 \quad 11696$

173,511

867,557
1,600

62,416

631,629 


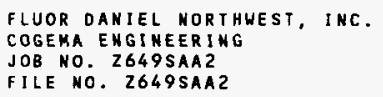

PAGE 15

\section{ACCOUNT}

NUMBER

DESCRIPTION

COST EQUIP

CODE QUANTITY MANHOURS LABOR USAGE

SUB - EQUIP- OH\&P TOTAL

NUMBER DESCRIPTION

320008 PROCESS EQUIPMENT DECON AND REPAIR

320008.15 MECHANICAL

EQUIPMENT \& REPAIR

501

1 Ls

o 0

o 5100000

o

$0 \quad 1275000$

6375000

320008,1500100 PROCUREMENT.

INSTALL MECHAHICAL PORTION

501

1 LS $\quad 31100 \quad 1375242$

0 $\quad 251175$

0

$0 \quad 406604 \quad 2033021$ \& REPAIR.

SUBTOTAL MECHANICAL

SALES TAX $8.00 \%$

OH\&P (OH MARKUPS ONLY)

TOTAL COST CODE 50115

COST CODE 50115
HBS 320008

SESCALATION

$0.00 X$ - CONTINGENCY

31,100

$$
31,100
$$

$1,375,242$

0

320008.16 ELECTRICAL

320008.1600100 INSTALL ELECTRICAL PORTION OF PROCESS EQUIPMENT DECON

501

1 LS

$20400 \quad 795804$

$0 \quad 404175$

0

$0 \quad 299995 \quad 1499974$

SUBTOTAL AND REPAIR.

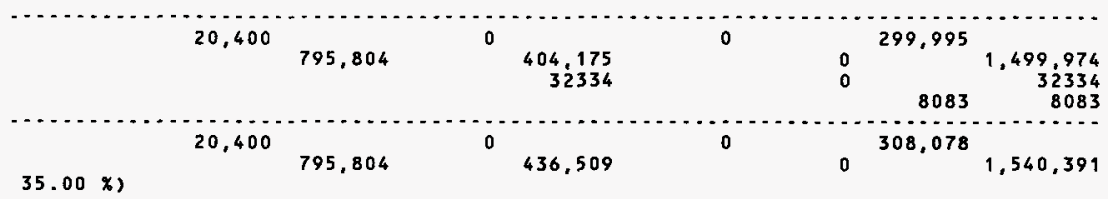

TOTAL WBS 320008 PROCESS EQUIPMENT DECON AND REPAIR

51,500

$2,171,046$
$6,215,778$
$2,096,706$

$10,483,530$ 
FLUOR OANIEL NORTHWEST, INC.

COGEMA ENGINEERING

JOB NO. Z649\$AA2

* * IEST - INTERACTIVE ESTIMATING * *

HTI TASK 7 PROCESS IMPACTS STUDY

CAPITAL COST ESTIMATE, REV 2

PHMCROQ - ESTIMATE DETAIL BY WBS, COST CODE

FILE NO. 2649SAA2
PAGE 16

DATE $02 / 12 / 99 \quad 15: 37: 47$

BY R.OHRT

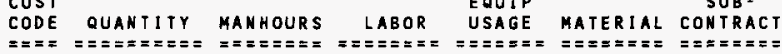

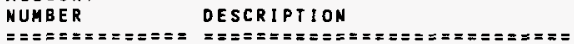

EQUIP -

EQUTP
HENT

OH\&P TOTAL

COMPRESSED AIR AND GAS

320009

320009.15
320009.1500100 MECHANICAL
INSTALL COMPRESSEO AIR AND GAS SYSTEM.

320009.1500110 THE ABOVE COSTS HERE ESCALATED FROM "SOLID WASTE TREATMENT FACILITY"

PARAMETRIC STUDY, DOCUMENT

320009.1500111 MUMBER HHC-EP-040́5.

SUBTOTAL MECHANICAL

SALES TAX $8.00 \%$

OH\&P (ON MARKUPS ONLY)

TOTAL

COST COOE 50115

NBS 320009

SESCALATION

$0.00 \%$ - CONTINGENCY $35.00 \%$

1508

4300

190146

0

0

35190

0

501

0

4.300

190,146

0

0

0

35

4,300

190,146

0

38,005

0

0

0

56334

281670
4,300

190,146 o

38.005
0

0

0

57.037

285,189 
FLUOR OANIEL HORTHWEST, INC.

COGEMA ENGINEERING

JOB HO. 2649SAA2

FILE NO. 2649SAA2

\section{ACCOUNT}

NUMBER

DESCRIPTION

* IEST - IMTERACTIVE ESTIMATING * *

HTI IASK 7 PROCESS IMPACTS STUDY

CAPITAL COST ESTIMATE, REV 2

PHMCRO8 - ESTIMATE DETAIL BY HBS, COST CODE
PAGE 17

DATE $02 / 12 / 99 \quad 15: 37: 47$

BY R.OHRT

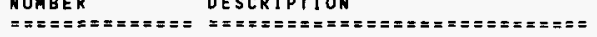

$\cos T$

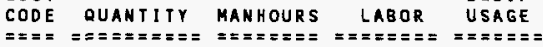

320010

PROCESS AIR

320010.15 MECHAMICAL

320010.1500100 INSTALL MECHANICAL PORTION OF PROCESS WATER SYSTEM.

320010.1500110 THE ABOVE COSTS UERE ESCALATED FROM "SOLID WASTE IREATHENT FACILITY" PARAMETR I C STUDY, DOCUMENT 320010.1500111 NUMBER WHC-EP-04Ó5.

SUBTOTAL MECHANICAL

SALES TAX $8.00 x$ OH\&P (ON MARKUPS OHLY)

TOTAL COST CODE 50115

WBS 320010 (ESCALATION

$0.00 \%$ - CONTINGENCY

$320010.16 \quad$ ELECTRICAL

320010.1600100 INSTALLELECTRICAL/INSTRUMENTATION PORTION OF THE

320010.1600110 THE ABOVE COSTS WERE ESCALATED FROM "SOLID WASTE TREATMENT FACILITY" PARAMETRIC STUDY, DOCUMENT 320010.1600111 NUMBER WHC-EP.0405.

SUBTOTAL ELECTRICAL

SALES TAX B.00\% OH\&P (ON MARKUPS ONLY)

TOTAL COST CODE 50116 WBS 320010 CESCALATION $0.00 X-$ CONTINGENCY

50

501

501

509

501

501
$35.00 \times 1$

$\begin{array}{ccccc}0 & 0 & 0 & 0 & 0 \\ 250 & & 0.753 & 0 & 24.225 \\ 1938\end{array}$

250

$$
\text { o }
$$

0

00

0

0

3,080

136,198

60,562
4844

3,080

136,198

65,406

$35.00 \%$

10

250

9753

$0 \quad 24225$

$$
0
$$

o

$\mathbf{0}$ $\begin{array}{llllll}1 \mathrm{JOB} & 3080 & 136198 & 0 & 60562\end{array}$

0

49190

245950

0

0

49,190

o

245,950

4844 1211

0

1211

50,401

252,006

0

8495

42473

0

0

0

0

8,495

0

484 1938
484 1938
484

979

44,895

0 
FLUOR DANIEL NORTHWEST, IHC.

COGEMA ENGINEERING

JOB NO. Z649SAA2

* IEST - INTERACTIVE ESTINATING *

HTI TASK 7 PROCESS IMPACTS STUDY

CAPITAL COST ESTIMATE, REV 2

PHMCRO8 - ESTIMATE DETAIL BY WBS/ COST CODE

COST
CODE GUANTITY MANHOURS LABOR LQUIP

COST
CODE GUANTITY MANHOURS LABOR LQUIP

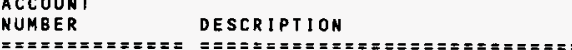

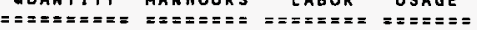

PAGE 18

DATE $02 / 12 / 99 \quad 15: 37: 47$

BY R.OHRT
NTRACT

MENT 1 B \& I DOLLARS

\section{RAW WATER \& FIREWATER}

320011.15 MECHANICAL

320011.1500100 INSTALL RAH HATER AND FIRE YATER SYSTEM.

320011.1500110 THE ABOVE COSTS WERE

ESCALATED FROM "SOLID WASTE

TREATMENT FACILITY"

PARAMETRIC STUDY, DOCUMENT

320011.1500111 HUMBER WHC-EP-0405.

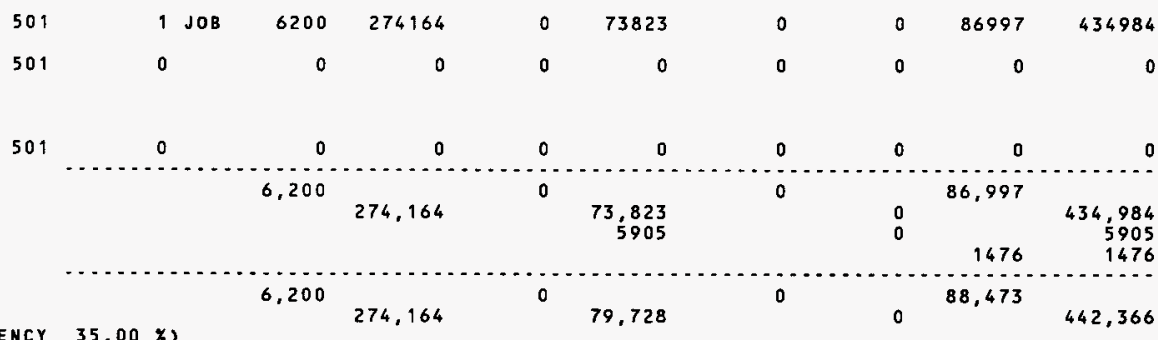

TOTAL MBS 320011 RAH HATER \& FIREUATER

6,200

274,164

o

79,728

0

88,473

442,366

SALES TAX $8.00 \%$

COST CODE 50115

UBS 320011

0.00\% - CONTINGENCY $35.00 \%$

$6,200 \quad 274,164$

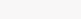




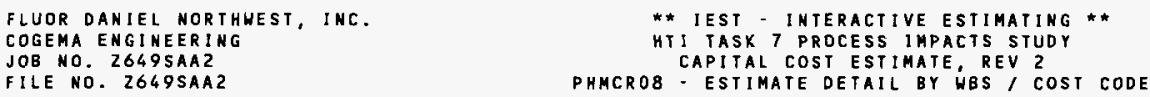

CODE QUANTITY MANHOURS LABOR USAGE

DESCRIPTION

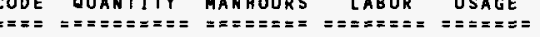

\section{SUB - \\ SUB -
STRAT}

PAGE 19

DATE $02 / 12 / 99 \quad 15: 37: 47$

BY R. OHRT

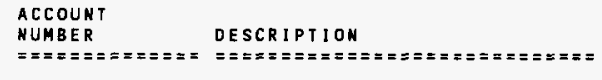

320012

DISTRIBUTED CONTROL SYSTEM

$320012.16 \quad$ ELECTRICAL

320012.1600050 DISTRIBUTED CONTROL SYSTEM ALLOWANCE FOR DCS HARDWARE SOFTHARE \& VENDOR SERVICES FOR CONTROL ROOH \& BLDG.

320012.1600100 FOR CONTROL ROOH \& BLDG SYSTEM (DCS)

320012.1600110 THE ABOVE COSTS HERE ESCALATED FROM "SOLID WASTE TREATMENT FACILITY"

PARAMETRIC STUDY DOCUMENT

320012.1600911 NUMBER WHC-EP-0405.

SUBTOTAL ELECTRICAL

SALES TAX $8.00 x$ OH\&P (ON MARKUPS ONLY)

TOTAL COST CODE 50116

HBS 320012

CESCALAT IOI

$0.00 \%$ - CONTINGENCY $35.00 \%$

501

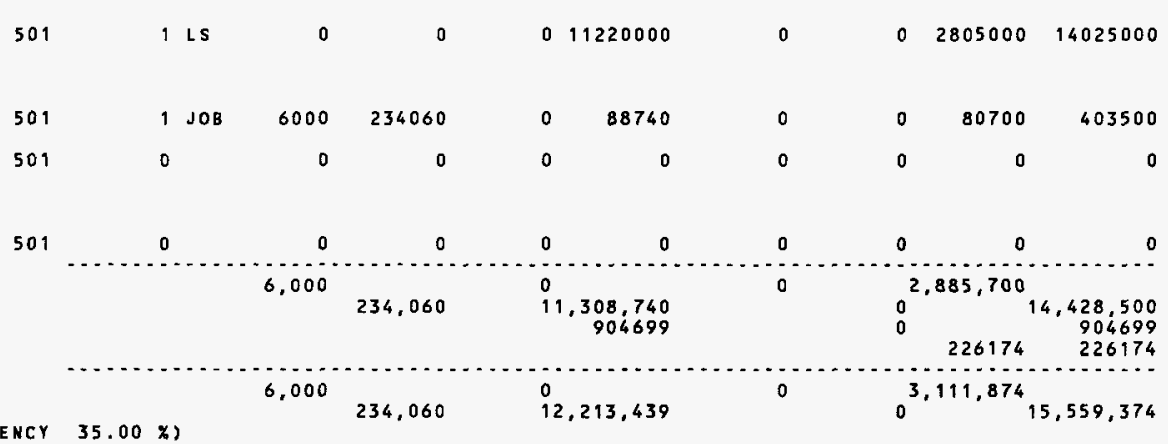

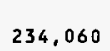

0 12,213,439
$0^{3,111,874}$ 


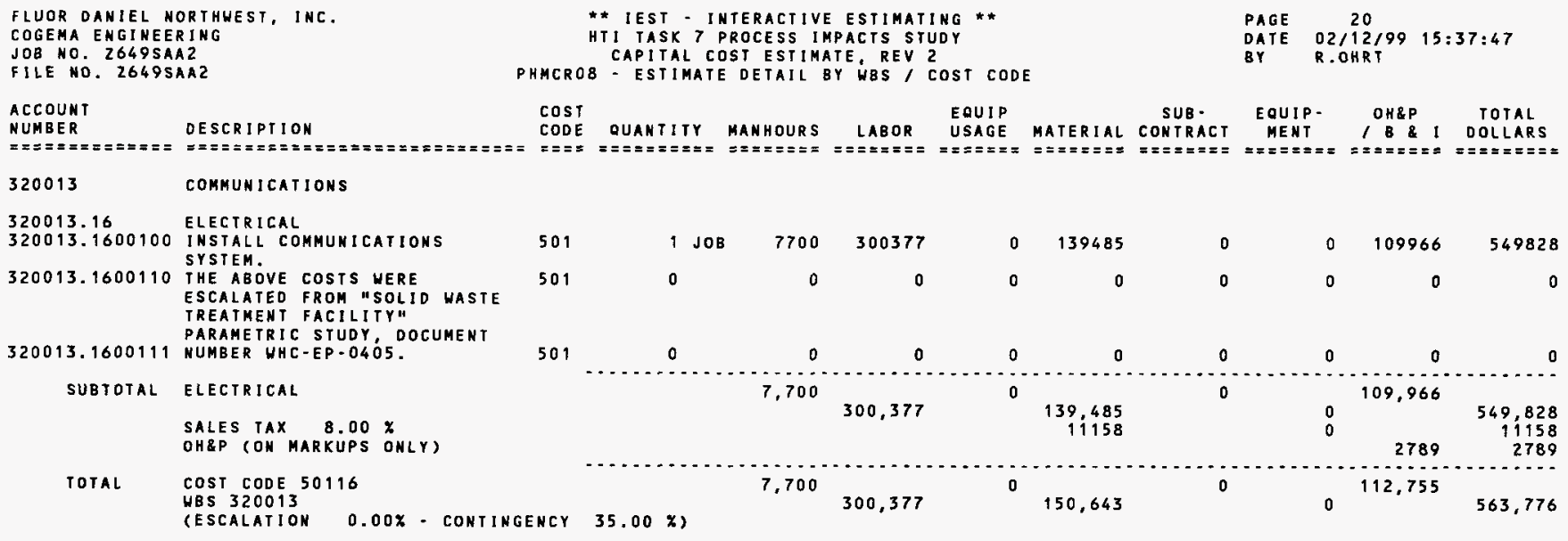

TOTAL WBS 320013 COMMUNICATIONS

7,700

300,377

150,643

12,755

563,776 
FLUOR DANIEL NORTHHEST, INC. COGEMA ENGINEERING

JOB NO. 2649SAA2

FILE HO. 2649SAA2

\section{ACCOUN T}

NUMBER

$$
\text { DESCR I P T ION }
$$

$== \pm===\pi======= \pm===$
ANALYIICAL FACILITIES

320014

MECHANICAL

320014.15

ANALYTICAL EQUIPMENT ALLOW- 50

ANCE - COMPUTER HARDHARE /

SOFTHARE VENDOR SERVICES

FOR CONTROL ROOM \& BUILDING

320014.1500100 INSTALL MECHANICAL PORTION

OF ANALYTICAL SYSTEM.

320014.1500110 THE ABOVE COSTS WERE

ESCALATED FROM "SOLID WASTE

TREATMENT FACILITY"

PARAHETRIC STUDY, DOCUMENT

320014.1500111 NUMBER WHC.EP-040́5.

SUBTOTAL MECHANICAL

SALES TAX $8.00 \%$

OH\&P (ON MARKUPS ONLY)

TOTAL COST CODE 50115

HBS 320014

CESCALATION

$0.00 \% \cdot$ CONTINGENCY

* IEST - interactive estimating *

HTI TASK 7 PROCESS IMPACTS STUDY

CAPITAL COST ESTIMATE, REV 2

PHMCROB - ESTIMATE DETAIL BY WBS/ COST CODE

$\cos T$

CODE OUANTITY MANHOURS LABOR USAGE

SUB - EQUIP-

OH\&P

TOTAL \begin{tabular}{ll} 
PAGE & \multicolumn{1}{|c}{21} \\
DATE & $02 / 12 / 99$ \\
BY & $15: 37: 47$ \\
R.OHRT
\end{tabular}

$=====+======================$ MATERIAL CON

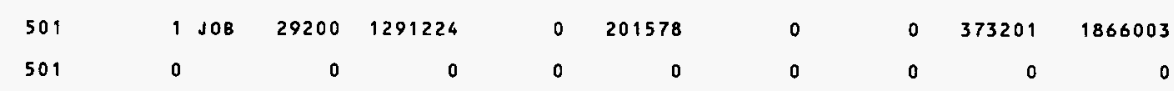

501

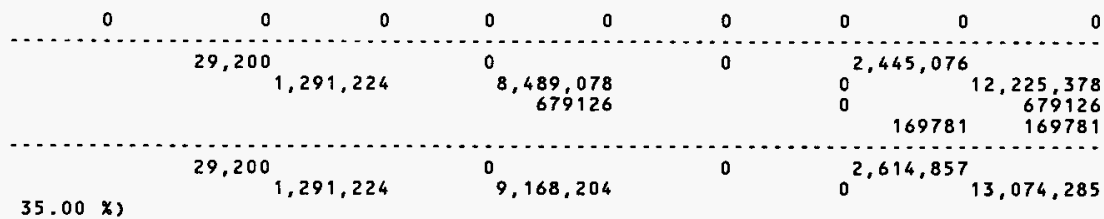

320014.16

ELECTRTCAL

320014.1600100 INSTALL ELECTRICAL/IHSTRUMENTATION FOR AHALYTICAL SYSTEM.

320014.1600110 THE ABOVE COSTS WERE ESCALATED FROH "SOLID WASTE TREATMENT FACILITYH

PARAMETRIC STUDY, DOCURENT

320014.1600111 NUMBER WHC-EP-040́5.

SUBTOTAL ELECTRICAL

SALES TAX $8.00 \%$ OH\&P (ON MARKUPS ONLY)

TOTAL COST COOE 50116

NBS 320014

CESCALATION

$0.00 \%$ - CONTINGENCY

50

$1 \mathrm{JOB}$

$7900 \quad 308179$

$0 \quad 227460$

o

$0 \quad 133910$

669549

50

o

0

o

0

0

0

0

0

o

501

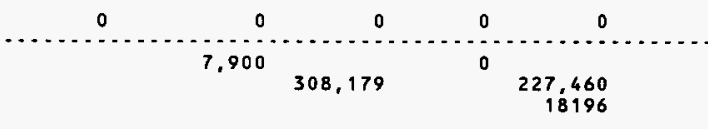

7,900

308,179

o

245,656

0

............

0

133,910

$4549 \quad 18196$

4549

$35.00 \% 3$ 
HNF-4098 Rev. 0

FLUOR DANIEL NORTHWEST, INC.

COGEMA ENGINEERING

JOB NO. 2649 SAAZ

FILE NO. Z649SAA2

\section{ACCOUNT}

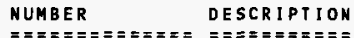

DESCR I PT ION

TOTAL WBS 320014 ANALYTICAL FACILITIES
* * IEST - INTERACTIVE ESTIMATING * *

HTI TASK 7 PROCESS IMPACTS STUDY

CAPITAL COST ESTIMATE, REV 2

PHMCROB - ESTIMATE DETAIL BY WBS/ COST CODE

COST QUATITY MANHOURS LABOR EQUIP
CODE USAGE

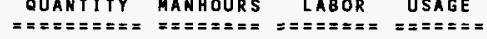

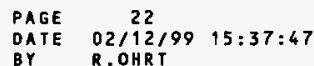

37,100

$1,599,403$
0

$9,413,861$
SUB MATERIAL CONTRACT
EQUIP- OH\&P TOTAL MENT $I$ B \& I DOLLARS

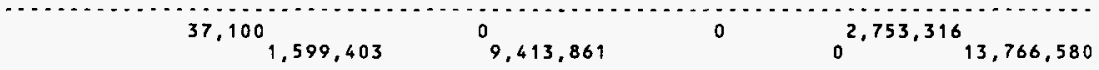


FLUOR DANIEL NORTHHEST, INC.

COGEMA ENGINEERING

JOB NO. Z649SAA2

* * IEST - INTERACTIVE ESTIMATING * *

HTI TASK 7 PROCESS IMPACTS STUDY

CAPITAL COST ESTIMATE, REV

FILE NO. 2649 SAA2

ACCOUNT

NUMBER DESCR I P I I ON

PHMCRO8 - ESTIMATE DETAIL BY WBS/ COST CODE

\section{COST EQUIP}

CODE QUANTITY MAKHOURS LABOR USAGE MATERIAL

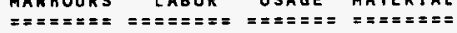

SUB

CONTRACT

$\begin{array}{lll}\text { PAGE } & 23 \\ \text { DATE } & 02 / 12 / 99 & 15: 37: 47\end{array}$

BY R. OHRT

320016

STACK \& FANHOUSE

320016.15 MECHANICAL

320016.1500050 STACK \& FANHOUSE ALLOWANCE, BASED ON PREVIOUS ESTIMATE 2466AAA2 DATED 09/18/97. PLUS AN ADDITIONAL AMOUNT OF 320016.1500051 \$2 MILLION FOR THE ADOED DUCTWORK REQUIRED FOR THE NEW CONFIGURATION.

SUBTOTAL MECHANICAL

SALES TAX $8.00 \%$ OH\&P (ON MARKUPS ONLY)

TOTAL

\section{COST CODE 50115}

WBS 320016

(ESCALATION

$0.00 \%$ - CONTINGENCY
501

501
$93477 \quad 3447432$

$0 \quad 7504661$

o

EQUIP-

MENT $I$ B \& I DOLLARS

$O H \& P$

TOTAL

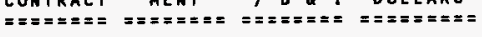

01

\section{0}

0

0

0

0

0

0

o

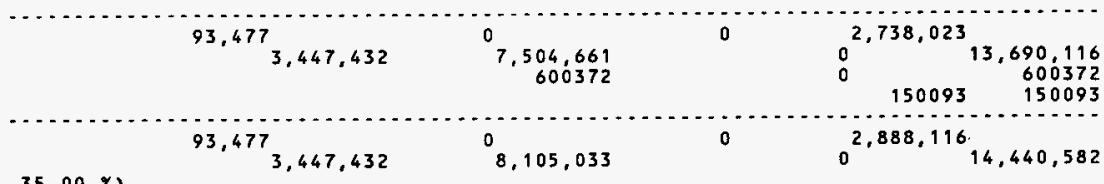

$35.00 \%)$

0

93,477

$3,447,432$
0

$8,105,033$
0
$0^{2,888,116}$ 


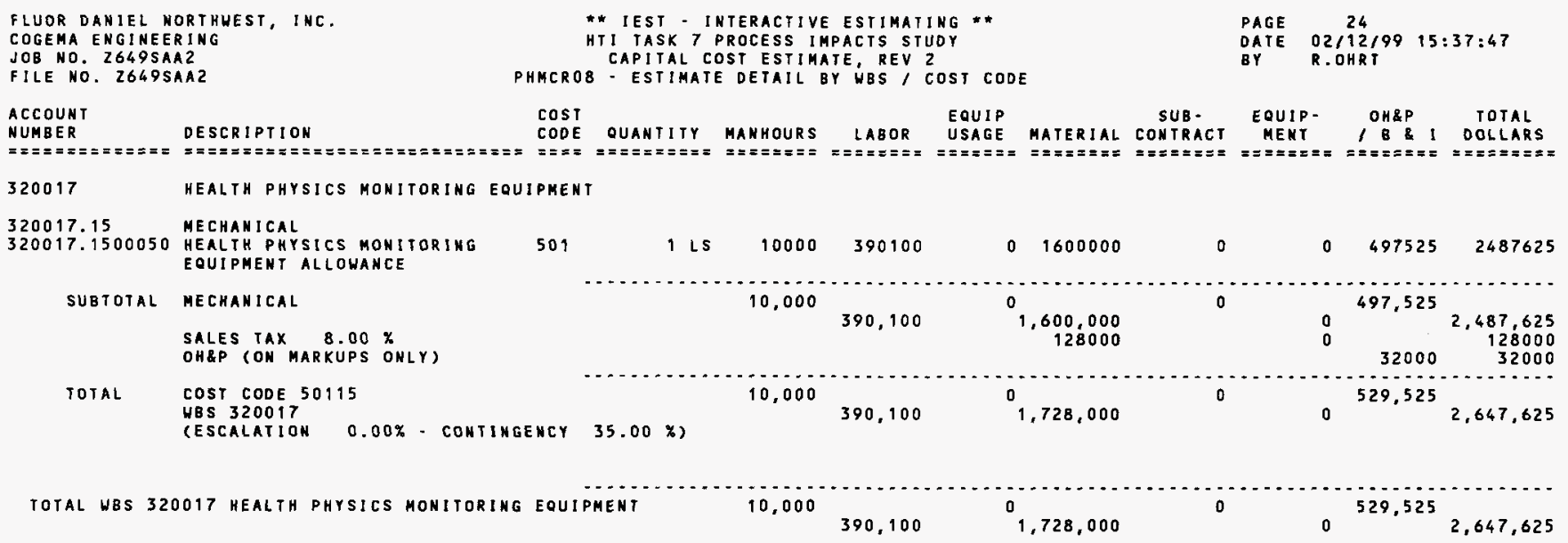




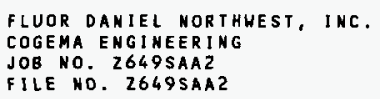

\section{ACCOUNT}

NUMBER

DESCRIPTION

* * IEST - INTERActIVE ESTIMATING * *

HTI TASK 7 PROCESS IMPACTS STUDY

CAPITAL COSTESTIMATE, REV 2

PAGE 25

DAIE $02 / 12 / 99 \quad 15: 37: 47$

BY R.OHRT

PHMCROB - ESTIMATE DETAIL BY WBS, COST CODE

\section{COST EQUIP} CODE QUANTITY MANHOURS LABOR USAGE MATERIAL CONTRACT MENT $/$ B I DOLLARS

SUB- EQUIP- OH\&P TOTAL

\section{2 CELL DRAINAGE/COLLECTION}

325002.15 MECHANICAL

325002.1500050 RADIOACTIVE LIQUID HASTE DRAIMAGE / COLLECTION SYSTEM PROCUREMENT.

325002.1500100 INSTALL MECHANICAL PORTION OF CELL DRAIMAGE/COLLECTION SYSTEM.

325002.1500110 THE ABOVE COSTS HERE ESCALATED FROM "SOLID WASTE TREATMENT FACILITY" PARAMETRIC STUDY, DOCUMENT 325002.1500111 NUMBER HHC-EP-040́5.

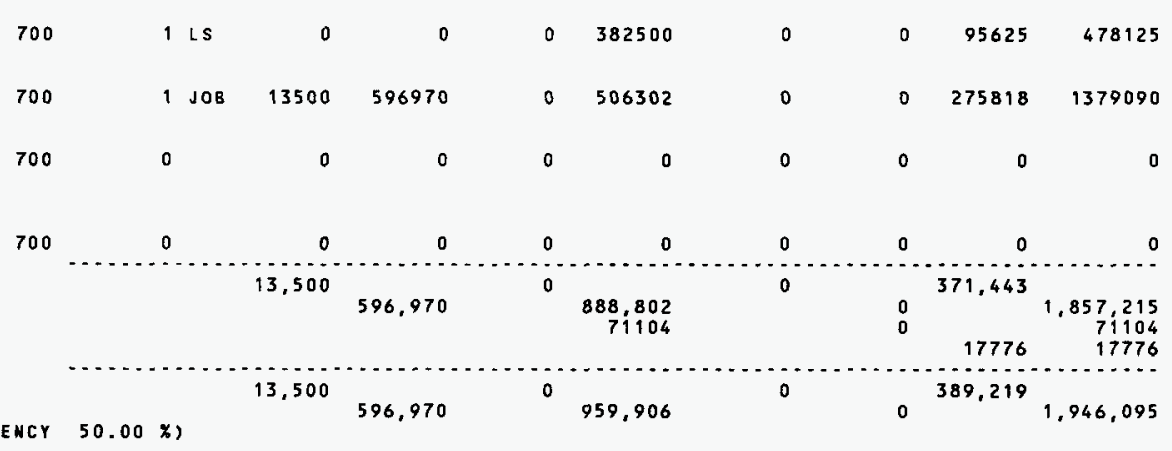

325002.16
325002.1600100 INSTALL ELECTRICAL/INSTRUINSTALL ELECTRICALIINSTR MENTATION PORTION OF THE
CELL DRAINAGE COLLECTION SYSTEM.

325002.1600110 THE ABOVE COSTS WERE ESCALATED FROM "SOLID WASTE TREATMENT FACILITY" PARAMETRIC STUDY, DOCUMENT

325002.1600111 NUMBER HHC-EP-040́5.

\section{SUBTOTAL ELECTRICAL}

SALES TAX $8.00 \%$ OH \&P (ON MARKUPS ONLY)

TOTAL COST COOE 70016 WBS 325002

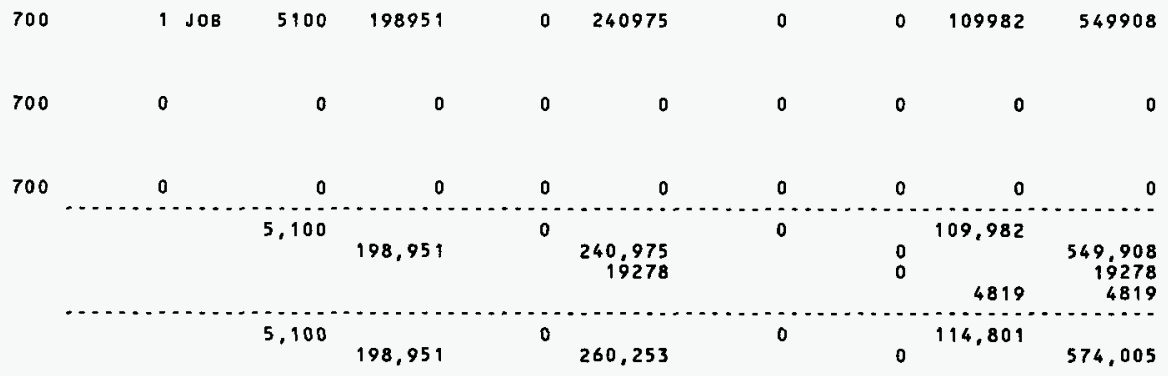


FLUOR DANIEL NORTHWEST, INC.

COGEMA ENGINEERING

JOB NO. 2649 SAA2

* * IEST - INTERACTIVE ESTIMATING * *

HTI TASK 7 PROCESS IMPACIS STUDY

CAPITAL COST ESTIMATE, REV 2

PHMCRO8 - ESTIMATE OETAIL BY HBS / COST CODE

\section{COST OUT OUATY MAMHOURS LQUIP}

CODE QUANTITY MANHOURS LABOR USAGE

DESCRIPTION

ACCOUNT

NUTBER = = = = = = = = = = = = = = = = = = = = = = =

$0.00 \%-$ CONIINGENCY

$50.00 \%)$
PAGE 26

DATE $02 / 12 / 99 \quad 15: 37: 47$

BY R.OHRT

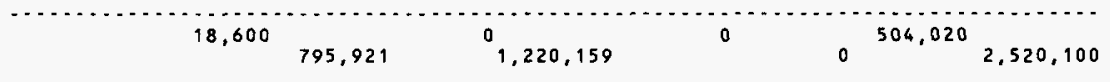




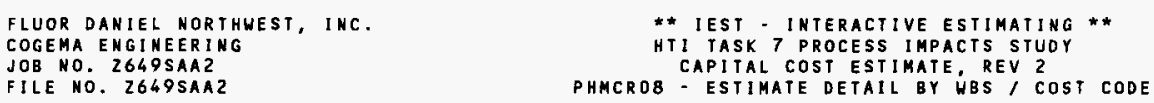

* IEST - INTERACTIVE ESTIMATING **

HTI TASK 7 PROCESS IMPACTS STUDY

CAPITAL COST ESTIMATE, REV 2

PHMCROB - ESTIMATE DETAIL BY WBS, COST CODE

\section{ACCOUNT}

NUMBER

DESCRIPTION

EQUIP

CODE QUANTITY MANHOURS LABOR USAGE

SUB

SUB - EQUIP. OHRP TOTAL

PAGE 27

DATE $02 / 12 / 99 \quad 15: 37: 47$

BY

R. OHRT

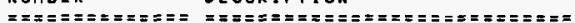

RAD SURVEY EQUIP. FOR WASHED SOLIOS

325003

MECHANICAL

325003.15

325003.1500050 RADIATION MONITORING

EOUIPMENT ALLOWANCE FOR

HARDWARE, SOFTWARE AHD

HARDWARE, SOFTWARE

325003.1500051 4 SEPARATE STATIONS TO SURVEY WASTE STREAHS CONT-

SURVEY WASTE STREAHS CONT-
AINING CAT 1 \& CAT 3 LLH.
325003.1500100 INSTALL MECHANICAL PORTION OF THE RADIATION SURVEY AND MONITORING SYSTEM.

325003.1500110 THE ABOVE COSTS UERE ESCALATED FROM "SOLID WASTE ESCRLATED FROM "SOLID PARAKETRIC STUDY, DOCUMENT 325003.1500111 NUMBER WHC-EP-040́5.

\section{SUBTOTAL MECHANICAL}

SALES TAX B.00\%

OHEP (ON MARKUPS ONLY)

TOTAL COST CODE 70015

\section{HBS 325003}

(ESCALATION

$0.00 \% \cdot$ CONTIHGEMCY

700

1 LS

0

$0 \quad 13937500$

$0 \quad 3484375$

17421875

700

0

o

o

0

0

0

0

0

o

700

$1 \mathrm{JOB}$

397980

D 143948

0

$0 \quad 135482$

677410

700

0

0

0

o

o

0

700

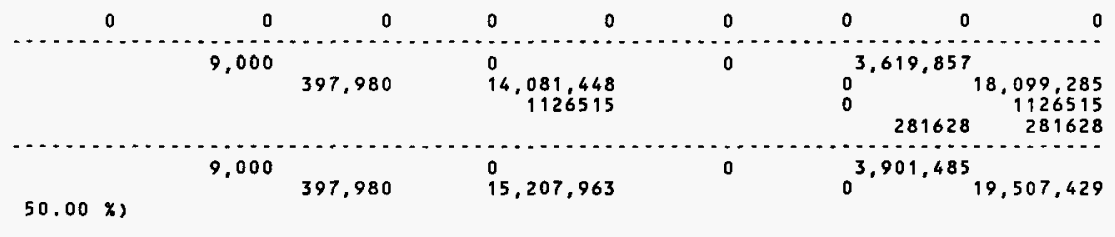

325003.16
325003.1600100 INSTALL ELECTRICAL/INSTRUELECTRICAL MENTATION PORTION OF THE RADIATION SURVEY AND RADIATION SURVEY AND

MONITORING SYSTEM.
325003.1600110 THE ABOVE COSTS WERE ESCALATED FROM "SOLID HASTE TREATMENT FACILITY" PARAMETRIC STUDY, DOCUMENT 325003.1600111 NUMBER WHC-EP-0405.

700

1,108

$23100 \quad 901131$

$0 \quad 446378$

$\mathbf{0}$

o

336877

1684386

700

0

0

0

0

0

0

0

0

700

0 0 0 0 0 0 0 0 23,100 901,131 0 446,378
35710 0 336,877 SALES TAX $8.00 \%$

23,10

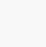

(2)




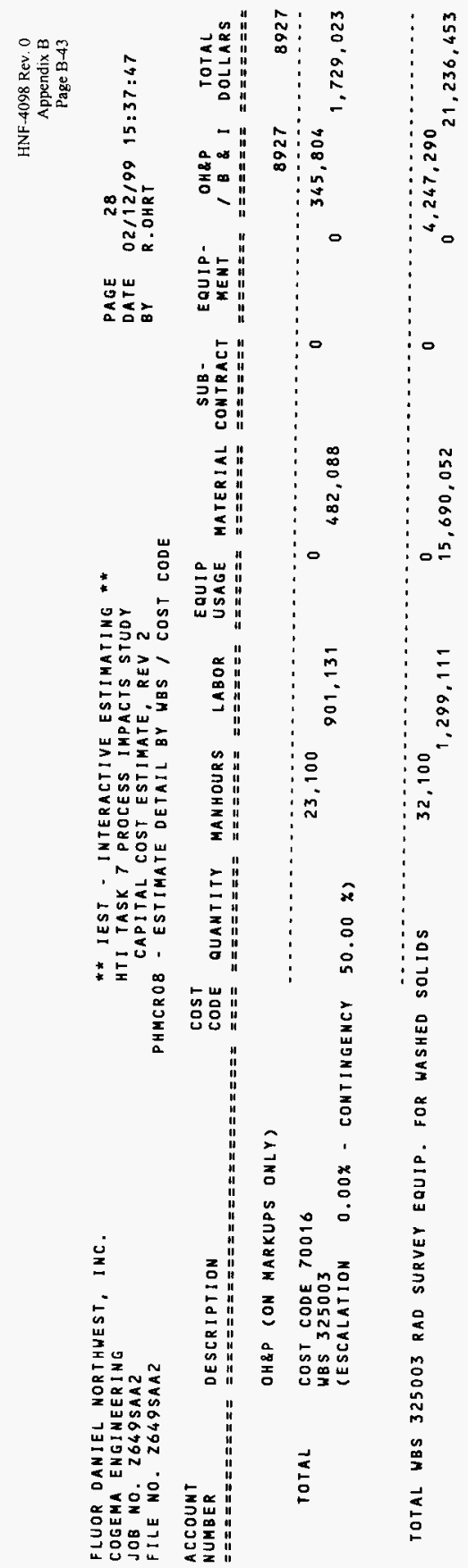


HNF-4098 Rev. 0

Appendix B

Page B-44

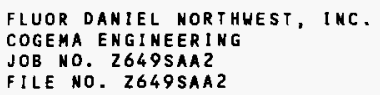

FILE NO. Z649\$AA2

PHMCROB - ESTIMATE DETAIL GY WBS / COST CODE

PAGE 29

DATE $02 / 12 / 99 \quad 15: 37: 47$

BY R.OHRT

\begin{tabular}{|c|c|c|c|c|c|c|c|c|c|c|c|}
\hline $\begin{array}{l}\text { ACCOUNT } \\
\text { NUMBER } \\
============\end{array}$ & 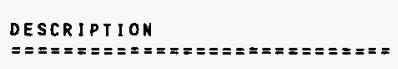 & $\begin{array}{l}\operatorname{COST} \\
\operatorname{CODE} \\
====\end{array}$ & $\begin{aligned} & \text { QUAN I I TY } \\
&========\end{aligned}$ & $\begin{array}{l}\text { RANHOURS } \\
=======\end{array}$ & $\begin{array}{c}\text { LABOR } \\
==== \pm===\end{array}$ & $\begin{array}{l}\text { EQUIP } \\
\text { USAGE } \\
====\equiv==\end{array}$ & $\begin{array}{l}\text { MATERIAL } \\
======= \pm\end{array}$ & $\begin{array}{l}\text { SUB- } \\
\text { CONTRACT } \\
=======\end{array}$ & $\begin{array}{l}\text { EQUIP- } \\
\text { MENT } \\
=======\end{array}$ & $\begin{array}{r}\text { OH\&P } \\
=======\end{array}$ & $\begin{array}{c}\text { IOTAL } \\
\text { OOLLARS } \\
==\approx=====\end{array}$ \\
\hline 325004 & PROCESS MONITORING INSTR. SYS & TEM & & & & & & & & & \\
\hline $\begin{array}{l}325004.16 \\
325004.1600050\end{array}$ & $\begin{array}{l}\text { ELECTRICAL } \\
\text { MIS PROCUREMENT ALLOHANCE - } \\
\text { COMPUTER HARDWARE/SOFTUARE } \\
\& \text { VENDOR SERVICES FOR } \\
\text { CONTROL ROOM \& BUILDING. }\end{array}$ & 700 & $1 \mathrm{LS}$ & 0 & 0 & 0 & 0 & 2167500 & 0 & 216750 & 2384250 \\
\hline 325004.1600100 & $\begin{array}{l}\text { INSTALL PROCESS MONITORING } \\
\text { INSTRUMENTATION SYSTEM (NIS) }\end{array}$ & 700 & 1 JOB & 300 & 11703 & 0 & 9818 & 0 & 0 & 5380 & 26901 \\
\hline 325004.1600110 & $\begin{array}{l}\text { THE ABOVE COSTS WERE } \\
\text { ESCALATED FROM "SOLID WASTE } \\
\text { TREATMEHT FACILITY" } \\
\text { PARAMETRIC STUDY, DOCUMENT }\end{array}$ & 700 & 0 & 0 & $\mathbf{0}$ & $\mathbf{0}$ & 0 & 0 & 0 & 0 & 0 \\
\hline 325004.1600111 & NUMBER WHC-EP- 0405 . & 700 & 0 & 0 & 0 & 0 & 0 & 0 & 0 & 0 & 0 \\
\hline SUBTOTAL & $\begin{array}{l}\text { ELECTRICAL } \\
\text { SALES TAX B.OO X } \\
\text { OH\&P (OH MARKUPS ONLY) }\end{array}$ & & & 300 & 11,703 & 0 & $9.818^{2}$ & & $\begin{array}{l}0 \\
0\end{array}$ & 222.130 & $\begin{array}{r}2,411,151 \\
785 \\
196\end{array}$ \\
\hline TOTAL & $\begin{array}{l}\text { COST CODE } 70016 \\
\text { WBS } 325004 \\
\text { SESCALATION } 0.00 \% \text { - CONTINGE }\end{array}$ & ENCY & $50.00 \%$ & 300 & 11,703 & 0 & $10,603^{2}$ & .500 & 0 & 222,326 & $2,412,132$ \\
\hline
\end{tabular}

TOTAL HBS 325004 PROCESS MONITORING INSTR. SYSTEM

300

11,703

$10,603^{2,167,500}$
222,326

$2,412,132$ 
FLUOR OANIEL NORTHWEST, INC.

COGEMA ENGINEERING

JOB NO. Z649SAA2

FILE NO. 2649SAA2

\section{ACCOUNT}

* IEST - INTERACTIVE ESTIMATIHG * *

HTI TASK 7 PROCESS IMPACTS STUDY

CAPITAL COST ESTIMATE, REV 2

PHMCROB - ESTIMATE DETAIL BY HBS/ COST CODE

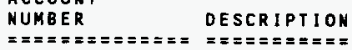

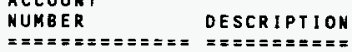

PAGE 30

DATE $02 / 12 / 99 \quad 15: 37: 47$

BY R.OHRT

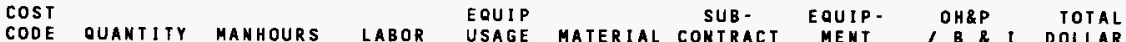

325005 AQUEOUS MAKE-UP

$325005.15 \quad$ MECHANICAL

325005.1500050 STORAGE AND MIXING TANKS FOR 700 ACID ANO CAUSTIC. 2 STORAGE TANKS AT 50,000 GAL AND 2

MIXING TANKS AT 10,000 GAL.

325005,1500100 INSTALL MECHANICAL PORTION INSTALL MECHANICAL PORTION
OF CHEMICAL RECEIPT ANO

MAKE-UP SYSTEM.
325005.1500110 THE ABOVE COSTS WERE ESCALATED FROM "SOLID HASTE TREATMENT FACILITY"

PARAMETRIC STUDY DOCUMENT

325005.1500111 NUMBER WHC-EP-040́5.

SUBTOTAL MECHANICAL

SALES TAX $8.00 \%$ OH\&P (ON MARKUPS ON(Y)

TOTAL COST CODE 70015

HBS 325005

SESCALATION

$0.00 \%$ - CONTINGENCY

700

0

0

$0 \quad 255000$

0

o

63750

318750

700

$1 \mathrm{JOB}$

$14600 \quad 645612$

$0 \quad 453900$

0

0

274878

1374390

700

0

0

0

0

0

0

0

0

o

700

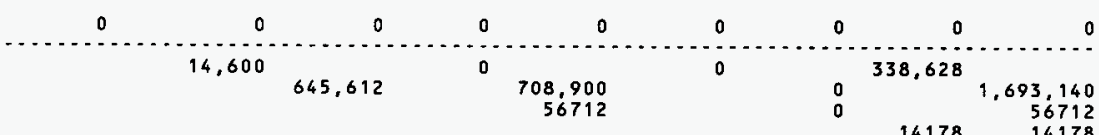

14,600

$50.00 x)$

14,600

645,612

o

14178

56712
14178

$\begin{array}{cc}14178 & 14178\end{array}$

325005.16 ELECTRICAL

325005.1600100 INSTALL ELECTRICAL/INSTRUMENTATION FOR CHEMICAL

RECEIPT AND MAKE-UP SYSTEM.

325005.1600110 THE ABOVE COSTS WERE

ESCALATED FROM "SOLID WASTE TREATMENT FACILITY"

PARAMETRIC STUDY, DOCUMENT

PARAMETRIC STUDY,
325005.1600111 NUMBER WHC-EP-0405.

\begin{tabular}{|c|c|c|c|c|c|c|c|c|c|}
\hline 700 & $1 \mathrm{JOB}$ & 11200 & 436912 & 0 & 316583 & 0 & 0 & 188374 & 941869 \\
\hline 700 & 0 & 0 & 0 & 0 & 0 & 0 & 0 & 0 & 0 \\
\hline 700 & 0 & 0 & 0 & 0 & 0 & 0 & 0 & 0 & 0 \\
\hline & & .00 & 436,912 & 0 & $\begin{array}{r}316,583 \\
25326\end{array}$ & 0 & $\begin{array}{l}0 \\
0\end{array}$ & $\begin{array}{r}188,374 \\
6331\end{array}$ & $\begin{array}{r}941,869 \\
25326 \\
6331\end{array}$ \\
\hline & & 11,200 & 436,912 & 0 & 341,909 & 0 & 0 & 194,705 & 973,527 \\
\hline
\end{tabular}

SUBTOTAL ELECTRICAL

SALES TAX 8.0O X OH\&P (ON MARKUPS DNLY)

TOTAL COST CODE 70016 WBS 325005

65.612

o

.......



NUMBER DESCRIPIION

CODE OUANTITY MANHOURS LABOR USAG

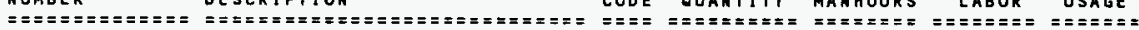

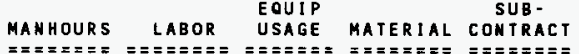

PAGE $\quad 31$

DATE $02 / 12 / 99 \quad 15: 37: 47$

BY R.OHRT

\section{(ESCALATION $0.00 \%$ - CONTIHGENCY $50.00 \%$ )}

TOTAL HBS 325005 AQUEOUS MAKE-UP

25,800

$$
1,082,524
$$

o
EQUIPMENT
OH\&P TOTAL B \& I DOLLARS
1 DOLP
$1,082.524 \quad 01,107,521$ 
FLUOR DANIEL NORTHWEST, INC.

COGEMA ENGINEERINO

JOB NO. 2649SAAZ

FILE NO. 2649SAA2

\section{ACCOUNT}

NUMBER

DESCRIPIIOH

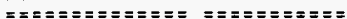

\section{6}

BRIDGE CRANES

325006.11 EQU I P MEN T

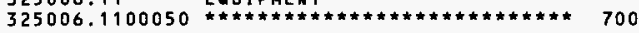

PROCESS AREA BRIDGE CRANE

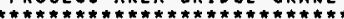

325006.1100055 MUCLEAR SERVICE BRIDGE CRANE 700 OVER PROCESS AREA SPANNIMG

100 FT WITH A 500 FT RUN

30 TON AND 5 TON HOOKS HITH

325006.110006030 FT LIFT. TO BE USED FOR

MAINTENANCE, SET UP AND

REMOVAL OF SKIDS ETC.

325006.1100065 QUOTE PER AMERICAN CRANE \& 700

EQUIPMENT CORPORAIION. $01 / 07 / 99$.

325006.1100070 SHIPPING

325006.1100075 INSTALLATION

325006,1100150 t*t*ata*

BRIDGE CRANE IN WASTE RECEIVING AREA

30 FT HIDE $\times 180$ FT TRAVEL, 700 WITH 5 TON ELECTROMAGNET AND 10 TON GRAPPLE.

325006.1100160 QUOTE PER AMERICAN CRANE\& EQUIPMENT CORPORATION, $01 / 07 / 99$.

325006.1100165 SHIPPING

325006.1100170 1NSTALLATION

\section{SUBTOTAL EQUIPMENT}

SALES TAX 8.00\% OH\&P (ON MARKUPS ONLY)

TOTAL

COST CODE 70011

UBS 325006

(ESCALATION $0.00 \%$ - CONTIHGENCY $50.00 \%$ )

100
* IEST - INTERACIIVE ESTIMATING *

HT I IASK 7 PROCESS IMPACTS SIUDY

CAPITAL COST ESTIMATE, REV 2

PHMCROB - ESTIMATE DETAIL BY WBS / COST CODE

MANTITY MANHOURS LABOR USAGE

SUB -

PAGE 32

DATE $02 / 12 / 99 \quad 15: 37: 47$ R. OHRT

\begin{tabular}{|c|c|c|c|c|c|c|c|c|c|}
\hline $\begin{array}{l}\text { CODE } \\
====\end{array}$ & $\begin{array}{l}\text { QUANTITY } \\
======= \pm\end{array}$ & $\begin{array}{l}\text { MANHOURS } \\
=======\end{array}$ & $\begin{aligned} & \text { LABOR } \\
&=======\end{aligned}$ & $\begin{array}{c}\text { USAGE } \\
======\end{array}$ & $\begin{array}{l}\text { MATERIAL } \\
==\equiv====\end{array}$ & $\begin{array}{l}\text { CONTRACT } \\
==\approx=\equiv===\end{array}$ & $\begin{array}{c}\text { MENT } \\
== \pm==\approx==\end{array}$ & $=======$ & $\begin{array}{c}\text { DOLLARS } \\
===\approx=\equiv=\equiv=\end{array}$ \\
\hline 700 & 0 & 0 & 0 & 0 & 0 & 0 & 0 & 0 & 0 \\
\hline 700 & $1 E A$ & 0 & 0 & 0 & 910000 & 0 & 0 & 227500 & 1137500 \\
\hline 700 & 0 & 0 & 0 & 0 & o & 0 & 0 & 0 & 0 \\
\hline 700 & 0 & 0 & 0 & 0 & 0 & 0 & 0 & 0 & 0 \\
\hline $\begin{array}{l}700 \\
700 \\
700\end{array}$ & $\begin{array}{ll}1 & E A \\
1 & E A \\
0 & \end{array}$ & $\begin{array}{r}0 \\
10000 \\
0\end{array}$ & $\begin{array}{r}0 \\
367200 \\
0\end{array}$ & $\begin{array}{l}0 \\
0 \\
0\end{array}$ & $\begin{array}{r}30000 \\
0 \\
0\end{array}$ & $\begin{array}{l}0 \\
0 \\
0\end{array}$ & $\begin{array}{l}0 \\
0 \\
0\end{array}$ & $\begin{array}{r}7500 \\
91800 \\
0\end{array}$ & $\begin{array}{r}37500 \\
459000 \\
0\end{array}$ \\
\hline 700 & $1 \mathrm{EA}$ & 0 & D & 0 & 790000 & 0 & 0 & 197500 & 987500 \\
\hline 700 & 0 & 0 & 0 & 0 & 0 & 0 & 0 & 0 & D \\
\hline $\begin{array}{l}700 \\
700\end{array}$ & $\begin{array}{ll}1 & E A \\
1 & E A\end{array}$ & $\begin{array}{r}0 \\
6000\end{array}$ & $\begin{array}{r}0 \\
220320\end{array}$ & $\begin{array}{l}0 \\
0\end{array}$ & $\begin{array}{r}20000 \\
0\end{array}$ & $\begin{array}{l}0 \\
0\end{array}$ & $\begin{array}{l}0 \\
0\end{array}$ & $\begin{array}{r}5000 \\
55080\end{array}$ & $\begin{array}{r}25000 \\
275400\end{array}$ \\
\hline
\end{tabular}

\begin{tabular}{|c|c|c|c|c|c|c|c|c|c|}
\hline $\begin{array}{l}\text { CODE } \\
====\end{array}$ & $\begin{array}{l}\text { QUANTITY } \\
======= \pm=\end{array}$ & $\begin{array}{l}\text { MANHOURS } \\
=======\end{array}$ & $\begin{array}{c}\text { LABOR } \\
=======\end{array}$ & $\begin{array}{c}\text { USAGE } \\
======\end{array}$ & $\begin{array}{l}\text { MATERIAL } \\
== \pm \approx====\end{array}$ & $\begin{array}{l}\text { CONTRACT } \\
==z====\end{array}$ & 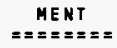 & $========$ & $\begin{array}{c}\text { DOLLARS } \\
==\approx= \pm== \pm=\end{array}$ \\
\hline 700 & 0 & 0 & 0 & 0 & 0 & 0 & 0 & 0 & 0 \\
\hline 700 & $1 E A$ & 0 & 0 & 0 & 910000 & 0 & 0 & 227500 & 1137500 \\
\hline 700 & 0 & 0 & 0 & 0 & $\mathbf{0}$ & 0 & 0 & 0 & 0 \\
\hline 700 & 0 & 0 & 0 & 0 & 0 & 0 & 0 & 0 & 0 \\
\hline $\begin{array}{l}700 \\
700 \\
700\end{array}$ & $\begin{array}{ll}1 & E A \\
1 & E A \\
0 & \end{array}$ & $\begin{array}{r}0 \\
10000 \\
0\end{array}$ & $\begin{array}{r}0 \\
367200 \\
0\end{array}$ & $\begin{array}{l}0 \\
0 \\
0\end{array}$ & $\begin{array}{r}30000 \\
0 \\
0\end{array}$ & $\begin{array}{l}0 \\
0 \\
0\end{array}$ & $\begin{array}{l}0 \\
0 \\
0\end{array}$ & $\begin{array}{r}7500 \\
91800 \\
0\end{array}$ & $\begin{array}{r}37500 \\
459000 \\
0\end{array}$ \\
\hline 700 & $1 E A$ & 0 & o & 0 & 790000 & 0 & 0 & 197500 & 987500 \\
\hline 700 & 0 & 0 & 0 & 0 & 0 & 0 & 0 & 0 & 0 \\
\hline $\begin{array}{l}700 \\
700\end{array}$ & $\begin{array}{ll}1 & E A \\
1 & E A\end{array}$ & $\begin{array}{r}0 \\
6000\end{array}$ & $\begin{array}{r}0 \\
220320\end{array}$ & $\begin{array}{l}0 \\
0\end{array}$ & $\begin{array}{r}20000 \\
0\end{array}$ & $\begin{array}{l}0 \\
0\end{array}$ & $\begin{array}{l}0 \\
0\end{array}$ & $\begin{array}{r}5000 \\
55080\end{array}$ & $\begin{array}{r}25000 \\
275400\end{array}$ \\
\hline
\end{tabular}

$\begin{array}{llllllllll}700 & 1 & \text { EA } & 0 & 0 & 0 & 20000 & 0 & 0 & 5000\end{array}$

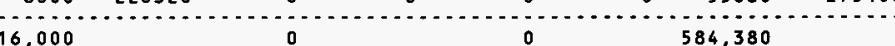

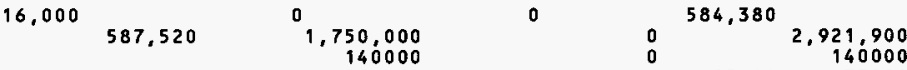

$16,000 \quad 0 \quad 619,380$

$3,096,900$

TOTAL WBS 325006 BRIDGE CRANES

16,000

587,520

0

$1,890,000$

0

619,380

$3,096,900$ 


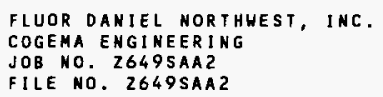

\section{ACCOUNT}

NUHBER

DESCRIPTION

PHMCRQ8 - ESTIMATE DETAIL BY HBS/ COST COOE

PAGE 33

DATE $02 / 12 / 99 \quad 15: 37: 47$

BY R.OHRT

COST EQUIP SUB- EQUIP- OH\&P TOTAL COOE QUANTITY MANHOURS LABOR USAGE MATERIAL CONTRACT MENTT/ B I DOLLARS

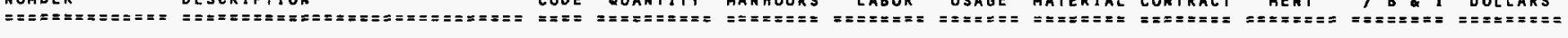

325008 ROBOTICS

$325008.11 \quad$ EQUIPHENT

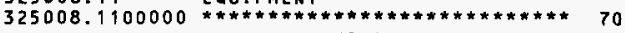

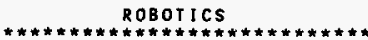

TOTAL

1 Ls

0

0

20000000

2000000

$\begin{array}{rlllllll}7 \text { LS } & 0 & 0 & 0 & 0 & 020000000 & 0 & 2000000 \\ 22000000\end{array}$

TOTAL WBS 325008 ROBOTICS

$0 \quad 0$

0

0

0

$20,000,000$

0

o

$20,000,000$

2,000,000

$0^{2}$

00

0

o

0

$2,000,000$

$22,000,000$ 
FLUOR DANIEL NORTHWEST, INC.

COGEMA ENGINEERING

JOB NO. Z649SAA?

FILE NO. 2649SAA2

\section{ACCOUNT}

NUMBER DESCRIPIION

325010

325010.15

15 MECHANICAL

325010.1500050 PROCESS VESSEL VENT EQUIP. MENT - SCRUBBER, EXHAUSTER BLOWER, HEATER, DEMISTER, BLOWER, HEATER, DE
PUMPS AND FILTERS.

325010.1500100 INSTALL MECHANICAL PORTION OF PROCESS VESSEL VENT SYSTEM.

SUBTOTAL MECHANICAL

SALES TAX $8,00 \%$ OH\&P (ON MARKUPS ONLY)

TOTAL COST CODE 70015 WBS 325010 (ESCALATION $0.00 \mathrm{X}$ - CONIINGEHCY

700

* IEST - INTERACTIVE ESTIHATING * *

HTI TASK 7 PROCESS IMPACTS STUDY

CAPITAL COST ESIIMATE, REV 2

PHMCROB - ESTIMATE DETAIL BY WBS / COST CODE

1 LS

0

0

700

$1<s$

$30200 \quad 1335444$
PAGE 34

DATE $02 / 12 / 99 \quad 15: 37: 47$

BY R.OHRT

COST
CODE QUANTITY MANHOURS LABOR UQUIP

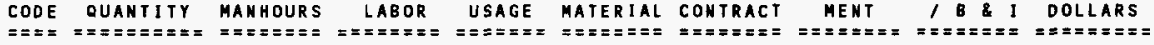
ELECTRICAL

325010.16

325010.1600100 INSTALL ELECTRICAL PORTION 700 OF PROCESS VESSEL VENT

$0 \quad 7777500$

$0 \quad 1944375$

9721875

$0 \quad 1530000$

0

$0 \quad 716361$

3581805 SYSTEM.

SUBTOTAL ELECTRICAL

SALES TAX $8.00 \%$

OH\&P (ON MARKUPS OHLY)

TOTAL

COST CODE 70016

WBS 325010

(ESCALATION

$0.00 \%$ - CONIINGENCY

0

$9,307,500$

744600

0

$1,335,444$

30,200

$1,335,444$

$10,052,100$

0

$50.00 \%$

1 LS $\quad 53300 \quad 2079233$

1224000

$\begin{array}{llll}0 & 0 & 825808 & 4129041\end{array}$

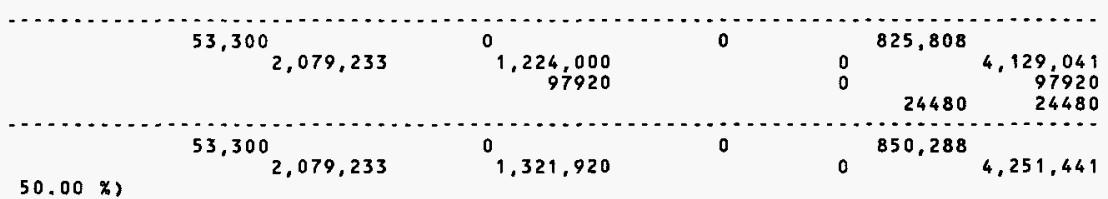

TOIAL WBS 325010 PROCESS VESSEL VENT

83,500

$3,414,677$

$11,374,020$

0

$3,697,176$

$18,485,871$ 
FLUOR DANIEL NORTHHEST, INC.

COGEMA ENGINEER ING

JOB NO. 2649SAA2

FILE NO. Z649SAA2

\section{ACCOUNT}

NUMBER

DESCRIPT I ON

$==\mathbf{=}=$

325011

$== \pm=== \pm==0+2$

MISC SERVICE PIPING

325011.15 MECHANICAL

325011.1500100 ADDITIONAL ALLOWANCE FOR PROCESS PIPING. ASSUME .1 LF/SF (X 140,000 SF) $=14000 \mathrm{LF}$

325011.1500110 ABOVE COSTS HERE PRORATED ESCALATED FROM "SOLIO WASTE TREATMENT FACILITY"

PARAMETRIC STUDY, DOCUMENT

325011.1500111 NUMBER HHC-EP-040́5.

SUBTOTAL MECHANICAL

SALES TAX $8.00 \%$ OH\&P (ON MARKUPS ONLY)

TOTAL

\section{COST CODE 70015}

WBS 325011

$0.00 \% \cdot \operatorname{CONTINGENCY}$
* * IEST - INTERACTIVE ESTIMATING * *

HTI TASK 7 PROCESS IMPACTS STUDY

CAPITAL COST ESTIMATE, REV 2

PHMCRO8 - ESTIMATE DETAIL BY WBS, COST CODE
PAGE 35

DATE $02 / 12 / 99 \quad 15: 37: 47$

BY R.OHRT COST
CODE QUANTITY MANHOURS LABOR USAGE MATERIAL CONTRACT MENT I OH\&P

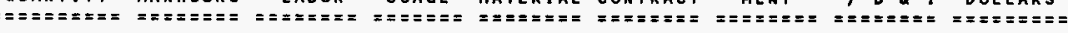

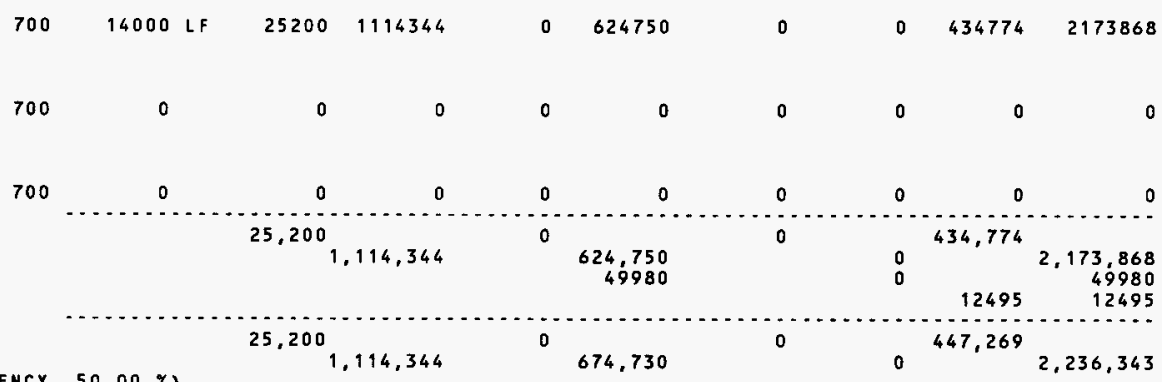


PAGE 36

DATE $02 / 12 / 99 \quad 15: 37: 47$

BY

FILE NO. Z649SAAL

\section{COST EQUIP \\ CODE QUANTITY MANHOURS LABOR USAGE} HUMBER DESCRIPTION

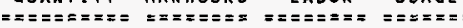

SUB -
MATERIAL CONTRAC

EQUIP. OH\&P TOTAL

325012 MATERIAL HANDLING

325012.14 CONVEYING SYSTEMS

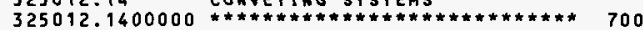

MATERIAL HANDLING SYSTEM

325012.1400002 APPROXIMATELY 840 LF OF 700

CONVEYOR IN HULTIPLE RUHS,

AND 140 BASKETS 2.2 ' $X 2.21$
$X 31 L$ SST HIPAYLOAD OF $1000 \%$

SUBTOTAL CONVEYING SYSTEMS

SALES TAX $8.00 \%$ OH\&P (ON MARKUPS ONLY)

TOTAL COST CODE 70014

HBS 325012

(ESCALATION

$0.00 \%$ - CONTINGENCY

0

1 LS

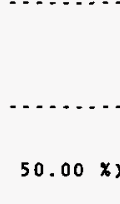

5,000

183,600

0

$15,300,000$

1224000

5,000

183,600

0

$16,524,000$

0

0

15300000

0

$0 \quad 3870900 \quad 19354500$

IOTAL WBS 325012 MATERIAL HANOLING

5,000

183,600
0

$16,524,000$ o

$4,176,900$

$20,884,500$ 
FLUOR DANIEL NORTHWEST, INC.

COGEMA ENG INEER ING

JOB NO. 2649SAA2

* IEST - INTERACTIVE ESTIMATING * *

HT I IASK 7 PROCESS IMPACTS SIUDY

CAPITAL COST ESTIMATE, REV?

PHMCROB - ESTIMATE DETALL BY WBS/ COST CODE

FILE NO. 2649SAAZ
PAGE 37

DATE $02 / 12 / 99 \quad 15: 37: 47$

R.OHR I
ACCOUNT

NUMBER

DESCR I PT ION

325014

325014.15

325014.1500000 MECHAMICAL

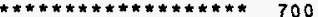

WASH STATION

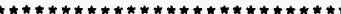

325014.15000022 REQ'D, 1 METER DEEP $X 1.5 M \quad 700$ WIDE $X$ SM LONG POOL. ALL SST W/200 GPM RECIRC. PUMP \& 85 GPM TRANSFER PUMP, ALLOHANCE

SUBTOTAL MECHANICAL

SALES TAX $8.00 \%$ OH\&P (ON MARKUPS ONLY)

TOTAL

COST CODE 70015

WBS 325014 (ESCALATION

$0.00 \%$ - CONTINGENCY
COST EQUIP

CODE QUANTITY MANHOURS LABOR USAGE

MATERIAL CONTRACI

SUB -

EQUIP - $\quad O H \& P$

OH\&P TOTAL

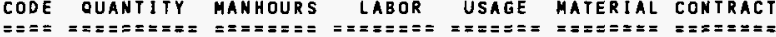

MENT

1 B \& 1 DOLLARS

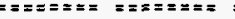

1 Ls
0

2000

88440

0

400000

0

122110
0

88,440

2,000

88,440

o
0

32000

122,110

432,000

o

130,110

o

32000

$50.00 \%)$

2,000

88,440

0

432.000

0

130,110

0 


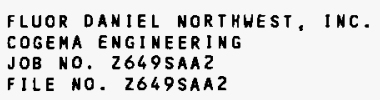

PAGE

BY

$02 / 12 /$ R. OHRT

\begin{tabular}{l} 
COST \\
CODE QUANTITY MANHOURS LABOR LQUIP \\
\hline
\end{tabular}

ACCOUNT
NUMBER DESCRIPIION

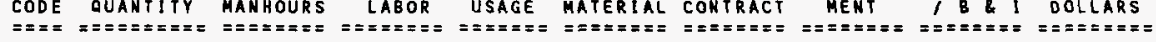

\section{6 \\ DRYER}

325016.15 MECHANICAL

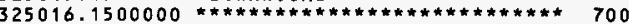
DRYER

$* * * * * * * * * * * * * * * * * * * * * * * * * * * *$
INSULATED UNIT, 56 FT LONG $X 700$ 12 FI HIGH X 6 FT HIDE WITH HEAT INPUT OF 2 MILLION BTU/HR.

325016.1500010 INSTALL DUCT, ASSUME 230 . 700 OF 18" DIA SST 16GA.

325016.1500020 INSTALL ELECTRICAL CABLE

325016,1500100 PRICE BASED ON QUOTATION BY STEVE GEE AT KLEENAIR PROD. $1-800-275-5152$.

SUBTOTAL MECHANICAL

SALES TAX $8.00 \%$

OH\&P (ON MARKUPS ONLY)

TOTAL

COST CODE 70015

WBS 325016

CESCALATIOH

$0.00 \%$ - CONTINGENCY $50.00 \%$ )
1 EA

0

o

0

2300

84456

0

1 LS

1 LS

690

14356

0

0

o

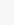

124,259

10,350
828

460.000

460,000

3,358

124,259

11,178

460,000

60,000

124,259

0

11,178

460.000

\section{3,358}

0

0

67114

TOTAL WBS 325016 DRYER
3,358

3,358

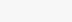




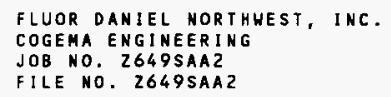

\section{ACCOUNT}

NUMBER

DESCRIPTION

PHMCRO8 - ESTIMATE DETAIL BY HBS/ COST CODE

PAGE 39

DATE $02 / 12 / 99 \quad 15: 37: 47$

BY R.OHRT

\section{COST EOUIP}

CODE QUANTITY MANHOURS LABOR USAGE

SUB - EQUIP -

QUIP- OH\&P

OH8P TOTAL

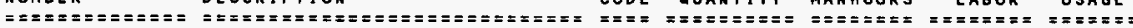

MATERIAL $\operatorname{con} \operatorname{sict}$

325018.15 MECHANICAL

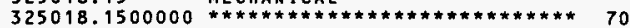
SHIELDED WASTE CONTAINERS

325018,1500002 4 FT HOTH

$\begin{array}{lllllllllll}700 & 0 & 0 & 0 & 0 & 0 & 0 & 0 & 0 & 0\end{array}$
FT LONG WITH 4" THK STEEL WALLS, COMPLETE WITH HARDWARE FOR LIFTING/UNLOADING. 325018.1500003 ALLOWANCE.
SUBTOTAL MECHANICAL

TOTAL

COST CODE 70015

WBS 325018 (ESCALATION

$0.00 \%$ - CONTINGENCY
700 0 0

0 0

0 0 0 0

$\begin{array}{lllll}0 & 0 & 12,500,000 & 1,250,000\end{array}$

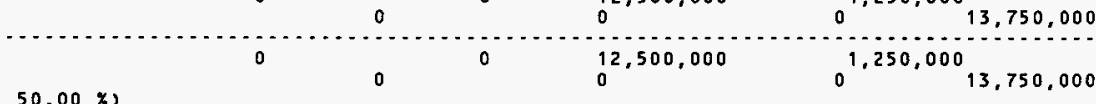

$1,250,000$

TOTAL WBS 325018 SHIELOED WASTE CONTAINERS
-

0
$12,500,000$
$1,250,000$

$13,750,000$ 


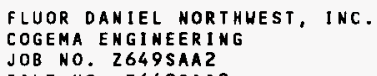

SUBTOTAL EQUIPMENT

SALES TAX $8.00 X$ OHEP (OH MARKUPS ONLY)

TOTAL
* IEST - INTERACTIVE ESTIMATING *

HTI TASK 7 PROCESS IMPACTS STUDY

CAPITAL COSTESTIMATE, REV 2

PHMCROS - ESTIMATE DETAIL BY WBS/ COST CODE
PAGE 40

DATE $02 / 12 / 99 \quad 15: 37: 47$

BY R.OHRT

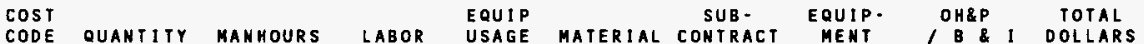

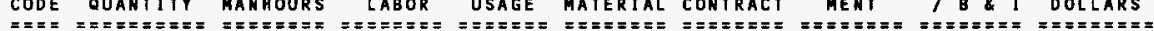

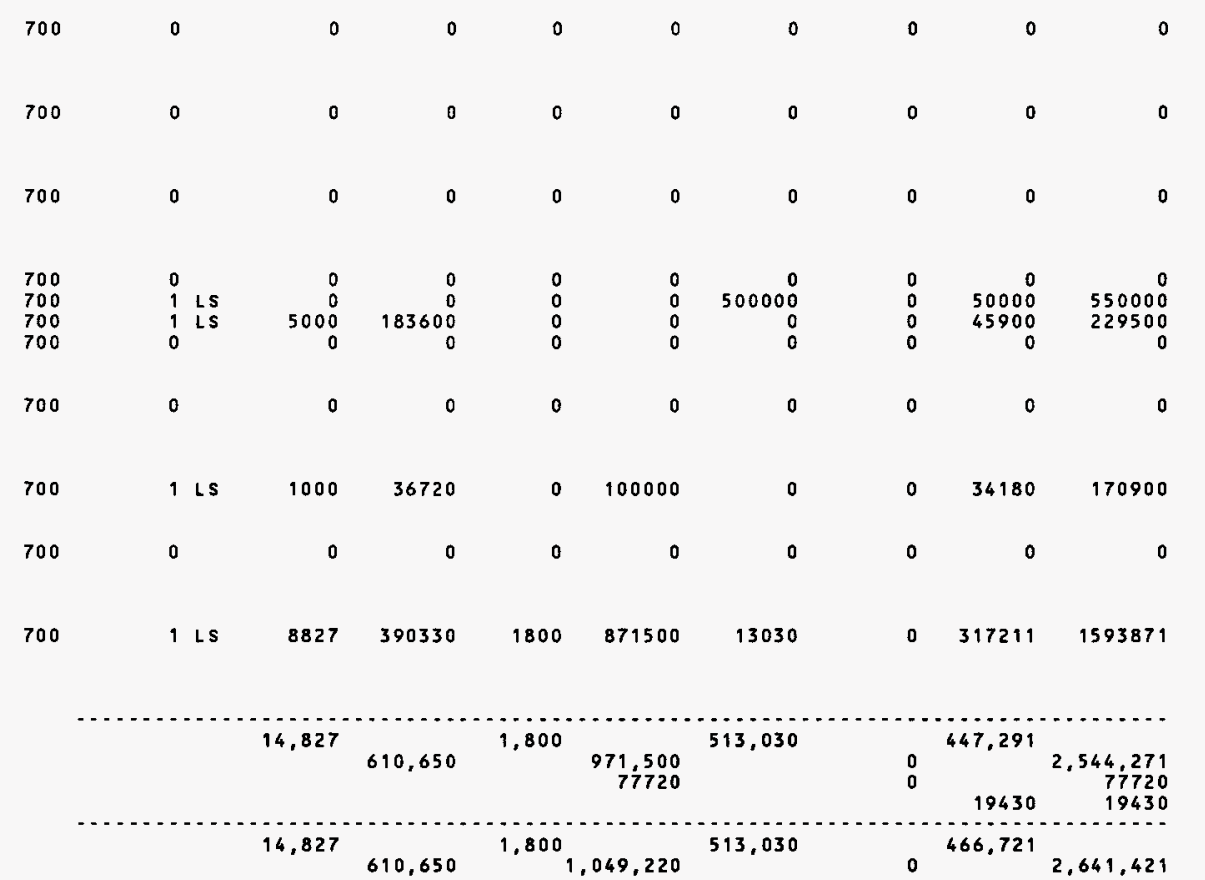


FLUOR DANIEL NORTHWEST, INC. COGEMA ENGI HEERING

JOB NO. 26495 AA2

FILE ND. 2649SAA2

** IEST - INTERACTIVE ESTIMATING *

HTI TASK 7 PROCESS IMPACIS STUDY

CAPITAL COSTESTIMATE, REV 2

PHMCRO8 - ESTIMATE DETAIL BY WBS / COST CODE

\section{ACCOUNT}

NUMBER

DESCRIPTION

COST EOUIP

CODE OUANTITY MANHOURS LABOR USAGE

MATERIAL CONTRACT

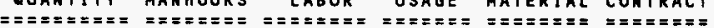

$0.00 \%$ - CONTINGENCY $50.00 \%$ )

SESCALATION

TOTAL WBS 325019 WASTE RECEIVING AREA

$14.827 \quad 610.650$

1,800

513,03

PAGE 41

BY

41

610,650

$1,049,220$

51030

EQUIP -

Q DOTAL

MENT

R.OHRT 
FLUOR DANIEL NORTHHEST, INC.

COGEMA ENGINEERING

JOB NO. 2649SAA2

* IEST - INTERACTIVE ESTIMATING * *

HTI TASK 7 PROCESS IMPACTS STUDY

CAPITAL COST ESTIMATE, REV 2

PHMCROB - ESTIMATE DETAIL BY WBS / COST CODE

FILE NO. 2649SAA2
PAGE 42

DATE $02 / 12 / 99 \quad 15: 37: 47$

BY R.OHRT

CODE QUANTITY MANHOURS LABOR USAGE

DESCRIPTION

MATERIAL CONTRACT

EQUIP- OH\&P TOTAL

MENT $I$ B \& I DOLLARS

NUMBER

SHREDDER

325023

$325023.11 \quad$ EQUIPMENT

年

SHREDDER

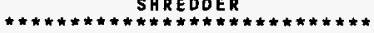

4 TON / HR CAPACITY

325023.1100002 SHREDDER UNIT TO REDUCE ALL

METAL TO 1-2" SHARDS AND

HAVE 1 " THICK PLATE CUTTING

CAPACITY.

325023.1100054 SHREDDER - ALLOUANCE

SUBTOTAL EQUIPMENT

SALES TAX $8.00 \%$

OH\&P (ON MARKUPS ONLY)

TOTAL

COST CODE 70011

WBS 325023

(ESCALATION

$0.00 \%$ - CONTINGENCY

700

$=== \pm==\approx==$

$=\mathbf{=}=\boldsymbol{x}=\mathbf{=}=$ $=== \pm==$

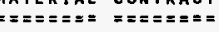

$\begin{array}{ccccccccc}700 & 0 & 0 & 0 & 0 & 0 & 0 & 0 & 0 \\ 700 & 0 & 0 & 0 & 0 & 0 & 0 & 0 & 0\end{array}$

700

1 EA

2868750

0

$0 \quad 740872$

3704360

................

$\begin{array}{llllll}2,580 & 94,738 & 0 & 0 & 740,872 & 0\end{array}$ $229500 \quad 0 \quad 3,704,360$

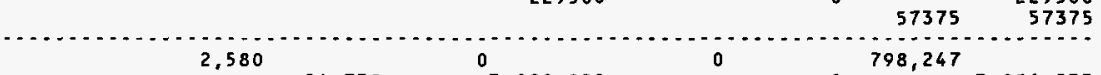

$50.00 \%)$

94,738

$3,098,250$

0

$3,991,235$

TOTAL WBS 325023 SHREDDER

0

$3,098,250$
0
798,247 
FLUOR DANIEL NORTHUEST, INC.

COGEMA ENGINEERING

JOB NO. 2649SAA2

* IEST - INTERACTIVE ESTIMATING * *

HT I TASK 7 PROCESS IMPACTS STUDY

CAPITAL COST ESTIMATE, REV 2

PHMCROB - ESTIMATE DETAIL BY WBS / COST CODE
PAGE 43

OATE $02 / 12 / 99 \quad 15: 37: 47$

BY

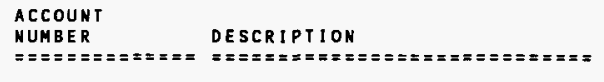

CODE QUANTITY MANHOURS LABOR USAGE

SUB -
MATERIAL CONTRACT

UB -

EQUIP- OH\&P TOTAL MENT, B \& I DOLLARS

325024

ACID DIGESTER

325024.15 MECHAMICAL

$325024.1500000 * * * * * * * * * * * \hbar * * * * * * * * * * * * * * * * 700$

$A C I D$ DIGESTER
$\star * * * * * * * * * * * * * * * * * * * * * * * * *$

$\begin{array}{cccccccccc}700 & 0 & 0 & 0 & 0 & 0 & 0 & 0 & 0\end{array}$

325024.1500002 LEACH TOWER WITH AUGER LIFT. 700 MULII-HEARTH FURNACE DESIGN OF 5 I DIA X 12' HIGH.

325024.15000036 TOH/HR SOLIDS, 15 GAL/MIN 700 ACID FEED. (ALLOUANCE)

SUBTOTAL MECHANICAL

SALES TAX $8.00 \%$ OH\&P (ON MARKUPS ONLY)

TOTAL

COST CODE 70015 WBS 325024 SESCALATION

$0.00 \%$ - CONTINGENCY $50.00 x$ )

\section{0}

660960

$0 \quad 300000$

0

0

o

0

18,000

660,960

300,000

24000

18,000

660,960

324,000

o

0 240240

1201200
18,000

660,960
0

324.000
0
266,240

0

$1,231.200$ 


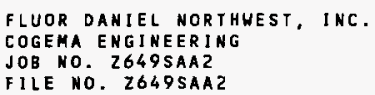

\section{ACCOUNT}

MUMBER

DESCRIPTION

* IEST - INTERACTIVE ESTIMATING **

HTI TASK 7 PROCESS IMPACTS STUDY

CAPITAL COST ESTIMATE, REV

PHMCROB - ESTIMATE DETALL BY WBS / COST CODE

EQUIP

CODE QUANTITY MANHOURS LABOR USAGE

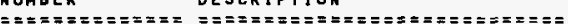
CODE ROTARY DRUM FILTER

325025 MECHANICAL

325025.15

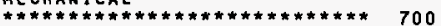
ROTARY DRUM FILTER

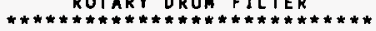

SUBTOTAL

MECHAN 1 CAL

SALES TAX $8.00 \%$ OH\&P (ON MARKUPS ONLY)

TOTAL COST CODE 70015

WBS 325025

(ESCALATIDN

0.00\% - CONTINGENCY

$\begin{array}{llllllllll}700 & 0 & 0 & 0 & 0 & 0 & 0 & 0 & 0 & 0 \\ 700 & 2 \text { EA } & 0 & 0 & 0 & 0 & 1500000 & 0 & 150000 & 1650000\end{array}$

\begin{tabular}{|c|c|c|c|c|c|c|c|c|c|}
\hline $\begin{array}{l}700 \\
700 \\
700 \\
700\end{array}$ & $\begin{array}{ll}1 & E A \\
1 & E A \\
1 & E A \\
1 & E A\end{array}$ & $\begin{array}{l}600 \\
120 \\
240 \\
240\end{array}$ & $\begin{array}{r}22032 \\
4406 \\
10613 \\
9362\end{array}$ & $\begin{array}{r}0 \\
1500 \\
0 \\
0\end{array}$ & $\begin{array}{r}3000 \\
0 \\
1500 \\
1500\end{array}$ & $\begin{array}{l}0 \\
0 \\
0 \\
0\end{array}$ & $\begin{array}{l}0 \\
0 \\
0 \\
0\end{array}$ & $\begin{array}{l}6258 \\
1477 \\
3028 \\
2716\end{array}$ & $\begin{array}{r}31290 \\
7383 \\
15141 \\
13578\end{array}$ \\
\hline & & 1,200 & 46,413 & 1,500 & $\begin{array}{r}6,000 \\
480\end{array}$ & & ${ }_{0}^{0}$ & $\begin{array}{r}163,479 \\
120\end{array}$ & $\begin{array}{r}1,717,392 \\
480 \\
120\end{array}$ \\
\hline & & 1,200 & 46,413 & 1,500 & 6,480 & 00 & 0 & 163,599 & $1,717,992$ \\
\hline
\end{tabular}




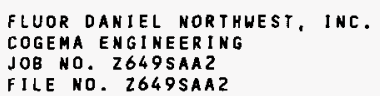

COST EQUIP

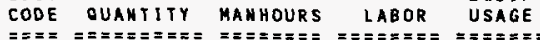

NUMBER DESCRIPTION

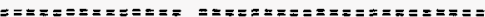

\section{PAGE 45 \\ DATE $02 / 12 / 99 \quad 15: 37: 47$ \\ BY R.OHRT}

325026 CENTRIFUGE

325026.15 MECHANICAL

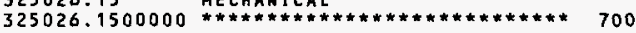
CENTRIFUGE $* * * * * * * * * * * * * * * * * * * * * * * * * * * *$

325026.1500002 CERTRIFUGE UITH FEED RATE 700 OF 50 GPM OF LIQUID HITH

325026.1500010 ARACE SOLIDS. ESCALATED FROM "SOLID WASTE TREATHENT FACILITYU PARAMETRIC STUDY, DOCUMEHT 325026.1500011 NUMBER HHC-EP-04Ó5.

SUBTOTAL MECHANICAL

SALES TAX $8.00 \%$ OH\&P (ON MARKUPS ONLY)

TOTAL COST CODE 70015 WBS 325026 (ESCALATION

$0.00 \%$ - CONTINGENCY $50.00 \%$ )

SUB -

EQUIP- OH\&P TOTAL

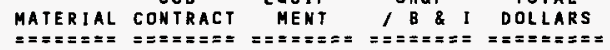

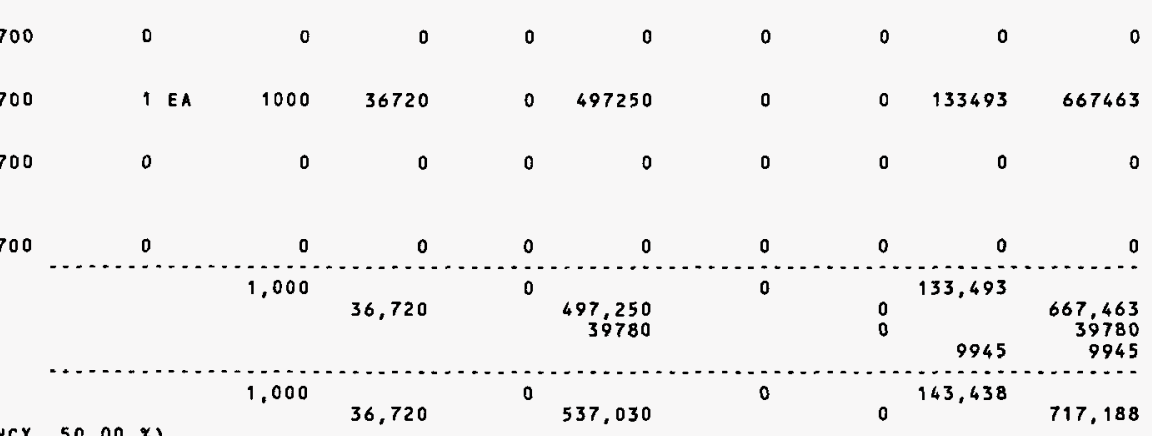

0

0

143,438 
FLUOR DANIEL NORTHUEST, IHC.

COGEMA ENGINEERING

JOB NO. 2649SAA2

** IEST - INTERACTIVE ESTIMATING * *

HTI TASK 7 PROCESS IMPACTS STUOY

CAPITAL COST ESTIMATE, REV 2

PHMCR08 - ESTIMATE OETAIL BY WBS, COST CODE

FILE NO. 2649SAA
PAGE 46

DATE $02 / 12 / 99 \quad 15: 37: 47$

BY

$\operatorname{COST}$

COST OUATITY MANROURS LABOR EQUIP MSAGE MATERIAL CONTRACT
CODE QUAT

DESCRIPTION

EOUTP. OH\&P TOTAL MENT $/$ B \& 1 DOLLARS NUMBER EVAPORATOR

325028 MECHANICAL

325028.15

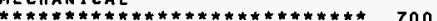
EVAPORATOR

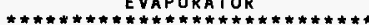

325028.1500000

325028.1500002 UNIT TO EVAPORATE 1750 GAL/ HR OF WATER FROM A SOLUTION

HR OF WATER FROM A SOLUTION
OF 2OX DISSOLVED SOLIDS.
325028.1500010 ABOVE COSTS WERE PRORATED \& ESCALATED FROM "SOLID WASTE TREATMENT FACILITY"

PARAMETRIC STUDY, DOCUMENT

325028.1500011 MUMBER HHC-EP-040́5.

700

700

0

0

0

0

0

0

0

700

$$
0
$$

$\begin{array}{ll}0 & 0 \\ 0 & 0\end{array}$

$0 \quad 12622500$

0

$1262250 \quad 13884750$

SUBTOTAL

MECHANICAL

TOTAL

COST CODE 70015

UBS 325028

$0.00 \%$ - CONTINGENCY $50.00 x$ )

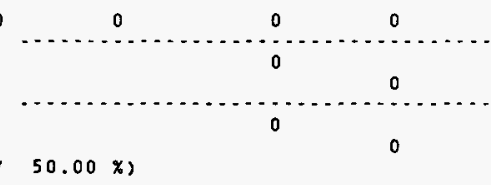

0

0

0

0

0

(ESCALATION

. . . . . . . . . . . .

0

o

0

o

0

0

0

$12,622,500$

0

$1,262,250$

0

$12,622,500$

$13,884,750$

TOTAL WBS 325028 EVAPORATOR

$12,622,500$

$0,262,250$

$13,884,750$

$1,262,250$ 
FLUOR DANLEL NORTHWEST, INC.

COGEMA ENGINEERING

JOB NO. 2649SAA2

FILE NO. 26495AA?

\section{ACCOUNT}

NUMBER

DESCRIPTION

$= \pm \pi==$

325029

GRINOING MILL

325029.15 MECHANICAL

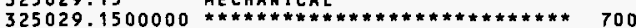
GRINDING MILL

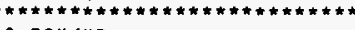
10 TON/HR

325029.1500002 FULLY AUTOGENOUS GRINDING MILL, APPROX 12'DIA X 10'L, 375-HP MOTOR, INCLUDES MOTOR, LINER, FEED AND

325029.1500003 DISCHARGE CHUTES QUOTE PER FFE MINERALS, BETHLEHEM, PA (610) 264-6171.

325029.1500004 SUPPORTS FOUNDATION AND INSTALLATION

SUBTDTAL MECHANICAL

SALES TAX 8.00\% OH\&P (ON MARKUPS ONLY)

TOTAL.

\section{COST CODE 70015}

NBS 325029 (ESCALATION

$0.00 \%$ - CONTINGENCY

700

700
* * IEST - INTERACTIVE ESTIMATING * *

HT I TASK 7 PROCESS IMPACTS STUDY

CAPITAL COST ESTIMATE REV 2

PHMCROB - ESTIMATE DETAIL BY WBS / COST CODE
PAGE 47

DATE $02 / 12 / 99 \quad 15: 37: 47$

BY R.OHRT
COST EQUIP SUB- EQUIP- OH\&P TOTAL CODE QUANTITY MANHOURS LABOR USAGE MATERIAL CONTRACT MENT $/$ B $I$ DOLLARS

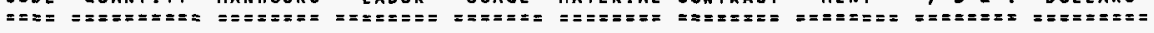

0

0

0

0

0

o

0

o

$0 \quad 1000000$

0

0

250000

1250000

1

$1 \mathrm{LS}$

0

0

o

0

0

0

0

0

-...............

10000367200
$\ldots \ldots \ldots$

10,000

367,200

0 100000

0

0

116800

584000

0

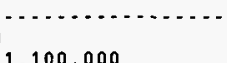

$10,000367,200$

$50.00 x)$

$1,188,000$

0

366,800

$\begin{array}{ll}0 & 1,834,000 \\ 0 & 88000\end{array}$ $22000 \quad 88000$ 22000.22000 388,800 $1.944,000$
10,000

367,200
0

188,000
0

-

388,800 
FLUOR DANIEL NORTHWEST, INC.
COGEMA ENGINEERING
JOB NO. Z649SAA2

FILE NO. Z649SAA2

\section{ACCOUNT}

NUMBER

DESCR IPTION

\# IEST - INTERACTIVE ESTIMATING *

HTI TASK 7 PROCESS IMPACIS STUDY

CAPITAL COST ESTIMATE, REV 2

PHMCRO8 - ESTIMATE DETAIL BY HBS/ COST CODE

EQUIP
PAGE 48

DATE $02 / 12 / 99 \quad 15: 37: 47$

BY R.OHRT

CODE QUANTITY MANHOURS LABOR USAGE MATERIAL CONTRACT MENT I B \& 1 DOLLARS

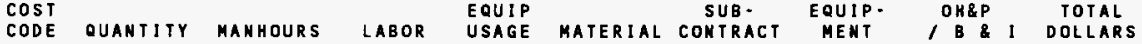

UQB - EQUIP.

TOTAL

325030

STAG ING TANKS

325030.15

325030.15
325030.1500000 MECHANICAL
$3 * * * * * * * * * * * * * * * * * * * * * * * * * * \quad 700$ SIAGING TANKS

325030.1500002 PER QUOTE FROM STEEL STRUCT- 700 URES, INC. ( 800$) 774-4774$. HORIZONTAL STORAGE TANK, 180 " OD X 72 ' LONG, 304 'SST,

325030.1500003 IHCLUDES LIFTING LUGS, 4 4" NOZZLES, 2 - 12" NÓZZLES AND 2 - 18 " MANWAYS. 80,000 LB .

325030.1500005 SHIPPING COST FOR TANKS.

325030.1500006 SET TANKS, 100,000 GAL EA.

325030.1500010 EXCAVATE HOLE FOR VAULT, BACKFILL AND HAUL.

325030.1500015 FORM AND POUR VAULT, 40' $x$ 80. $X 20^{\circ}$ DEEP, 2 FT HALLS AND COVER BLOCKS.

325030.1500020 PUMPS, 2 MIXING AHO 2 TRANSFER PUMPS, 50-100 GPM.

SUBTOTAL MECHANICAL

SALES TAX $8.00 \%$ OH\&P (ON MARKUPS ONLY)

TOTAL

COST CODE 70015

UBS 325030 (ESCALATION

0.00X - CONTIHGENCY

$\begin{array}{lllllll}0 & 0 & 0 & 0 & 0 & 0 & 0\end{array}$

2 EA

0

0

$0 \quad 500000$

0

$0 \quad 125000$

625000

700

0

o

0

0

o

0

o

o

o

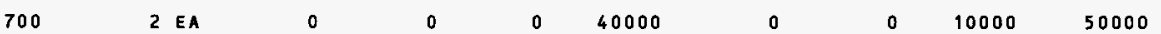

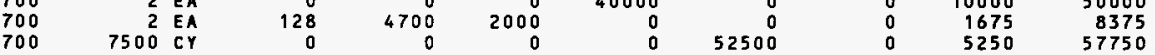

415000

$0 \quad 41500$

456500

700

1 LS

$200 \quad 7344$

$0 \quad 5000$

0

0 3086

15430

-.....................

328

12,044

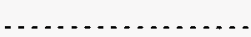

- .

186,51

$1,213,055$

$\begin{array}{rrr}5,000 & 0 & 1,213,055 \\ 4600 & 0 & 43600\end{array}$

32

$\begin{array}{lllll}328,044 & 2,000 & & 467,500 & 197,411\end{array}$

10900

10900

$1,267,555$

\begin{abstract}
TOTAL WBS 325030 STAGING TAHKS
\end{abstract}


FLUOR DANIEL NORTHHEST, INC.

COGEMA ENGINEER ING

JOB NO. Z649SAA2

FILE MO. Z649SAAZ

\section{ACCOUNT}

NUMBER

$\begin{array}{ll}\text { DESCRIPIION } & \text { COS } \\ \text { COD }\end{array}$

* IEST - INTERACTIVE ESTIMATING * *

HII TASK 7 PROCESS IMPACTS STUOY

CAPITAL COST ESTIMATE, REV 2

PHMCRO8 - ESTIMATE DETAIL BY WBS / COST CODE
PAGE 49

DATE $02 / 12 / 99 \quad 15: 37: 47$

R.OHR

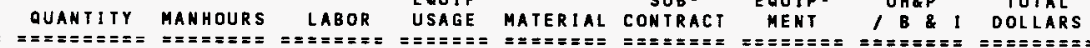

\section{MATERIAL CONTRACT MQUIP-}

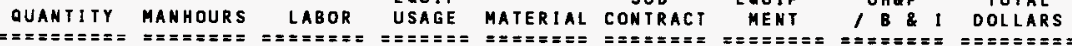

OH\&P, TOTAL

325031

CAT 1 LOADING STATION

325031.11 EQUIPMENT

325031.1100000

FOUR - COMPARTMENT AREA FOR DELIVERING AND PICKING UP

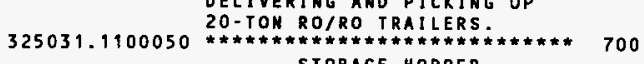
STORAGE HOPPER

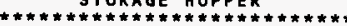

325031.1100055 THE HOPPER IS APPROX $50 \mathrm{FT}$

LONG, 20 FT WIDE ANO $20 \mathrm{FT}$

DEEP WITH SPRAY RING, SLOPED

FLOOR HITH VIBRATORY PAN

325031.1100060 FEEDER

325031.1100080 FABRICATION ALLOHANCE,

ASSUMING 40,000 LB AMO

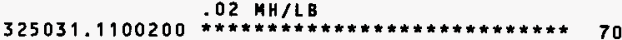

DECON AND RAD SURVEY EQUIP-

MENT IN THIRD COMPARTMENT

325031.1100205 THIS COST HAS BEEN TAKEN FROM A SIMILAR STUOY FOR THE AX TANK FARM ERCLOSURE STRUCTURE AHD ESCALATED.

SUBTOTAL EQUIPMENT

SALES TAX $8.00 \%$ OH\&P (ON MARKUPS ONLY)

TOTAL

COST CODE 70011
WBS 325031

IESCALATION

$0.00 \%$ - CONTINGERCY
o

0

0

o

0

0

0

\section{0}

0

700

700

700

700

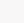

i L

0

1 LS

$8827 \quad 390330$

1800

871500

13030

o 317211

1593871

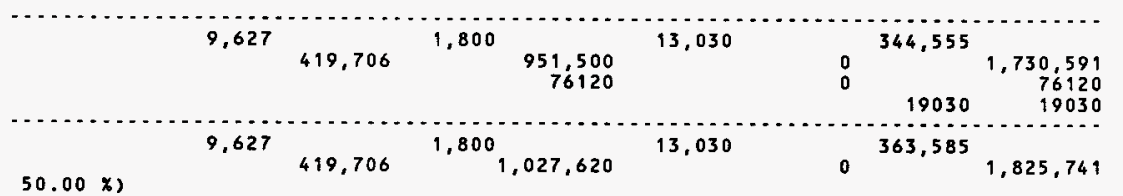

9.627

419.706

1,800

$1,027,620$

13,030

363,585 
FLUOR DANIEL NORTHWEST, INC.

COGEMA ENGINEERING

JOB NO. 2649 SAA2

FILE NO. Z649SAA2

\section{ACCOUNT}

NUMBER

DESCR IPT ION

* IEST - INTERACTIVE estimatimg * *

HT I TASK 7 PROCESS IMPACTS STUDY

CAPITAL COST ESTIMATE, REV 2

PHMCROB - ESTIMATE DETAIL BY WBS, COST CODE
PAGE 50

DATE $02 / 12 / 99 \quad 15: 37: 47$

BY R.OKRT

COST EQUIP SUB - EQUIP. OH\&P TOTAL

CODE QUANTITY MANHOURS LABOR USAGE MATERIAL CONTRACT MENT I B \& I DOLLARS

325032

CAT 3 CONCRETING/LOADING STATION

325032.15 MECHANICAL

$325032.1500000 * * * * * * * * * * * * * * * * * * * * * * * * * * * * 700$

CAT 3 CONCRETING/LOADING

$$
\text { STATION }
$$

325032.1500002 FOR BULK CONTAIHERS OF

PALLET SIZE TO ADD AND MIX

CEMENT AGENTS TO TARGET

MATERIAL. 4 CYIHR CAPACITY.

SUBTOTAL MECHANICAL

SALES TAX $8.00 \%$

OH\&P (ON MARKUPS ONLY)

TOTAL

COST CODE 70015

UBS 325032

(ESCALATION 0.00X - CONTINGENCY $50.00 x$ )

0

0

0

0

0

700

$1 \mathrm{LS}$

$1500 \quad 66330$

$0 \quad 187500$

o

0

63458

317288

325032.16 ELECTRICAL

325032.1600002 ELECTRICAL PORTIOH OF LOADING STATION, CONTROLS

700

1,500
1,500
$50.00 \quad(x)$

0

187,500

0

63,458

15000

\section{SUBTOTAL ELECTRICAL}

SALES TAX 8.00\%

OH\&P (ON MARKUPS ONLY)

TOTAL COST CODE 70016

HBS 325032

UBS 325032

$0.00 \%$ - CONTINGENCY

000

202,500

1000

o

1225

6126

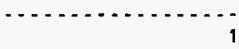

100

3,901

0

1,000

0

80

100

3,901

0

1.080

.

0

1,600

70,231

0

203,580

0

68,453

342,264 
FLUOR DANIEL NORTHUEST, INC.

COGEMA ENGINEERIHG

JOB NO. Z649SAA2

FILE NO. 2649 SAA2

ACCOUNT

HUMB ER

DESCRIPI ION

* * IEST - INTERACTIVE ESTIMATING * *

HTI TASK 7 PROCESS IMPACTS STUDY

CAPITAL COST ESTIMATE, REV 2

PHMCROB - ESTIMATE DETAIL BY WBS/ COST CODE

CODE QUANTITY

SUB-
HATERIAL CONTRACT

$\begin{array}{lcl}\text { PAGE } & 51 \\ \text { DATE } & 02 / 12 / 99 & 15: 37: 47\end{array}$

BY R, OHR T

\section{$325033 \quad$ JUMPERS}

325033.15 MECHANICAL

325033.1500000

$* * * * * * * * 700$

JUMPERS

$* * * * * * * * * * * * * * * * * * * * * * * * * * * *$

325033.1500001 MECHANICAL JUMPERS ALLOHANCE 700

FOR IN CELL EOUIPMEMT

700

ABOVE COSTS WERE PRORATED \& 700

325033.1500010 ABOVE COSTS WERE PRORATED
ESCALATED FROM "SOLID WASTE
TREATMENT FACILITY"
PARAMETRIC STUDY, DOCUMENT

325033.1500010 ABOVE COSTS WERE PROR
ESCALATED FROM "SOL
TREATMENT FACILITY"
PARAMETRIC STUDY, DOC

325033.1500010 ABOVE COSTS WERE PRORATED
ESCALATED FROM "SOLIO HASTE
TREATMENT FACILITY"
PARAMETRIC STUDY, DOCUMEHT

00

0

50 EA

0

700

\section{SUBTOTAL MECHANICAL}

TOTAL

\section{COST CODE 70015}

WBS 325033

IESCALATION

$0.00 \%$ - CONTIHGENCY

$325033.16 \quad$ ELECTRICAL

325033.1600001 ELECTRICAL JUMPERS ALLOWANCE 700

FOR IN CELL EQUIPMENT

325033.1600010 ABOVE COSTS WERE PRORATED \& 700

ESCALATED FROM "SOLID HASTE

TREATMENT FACILITY"

PARANETRIC STUDY, DOCUMENT

325033.1600011 NUMBER WHC-EP-04D́5.

SUBTOTAL ELECTRICAL

TOTAL

COST CODE 70016

WBS 325033

CESCALATION

$0.00 \%$ - CONTINGEHCY
700

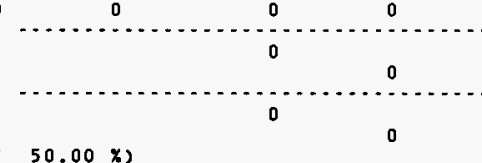

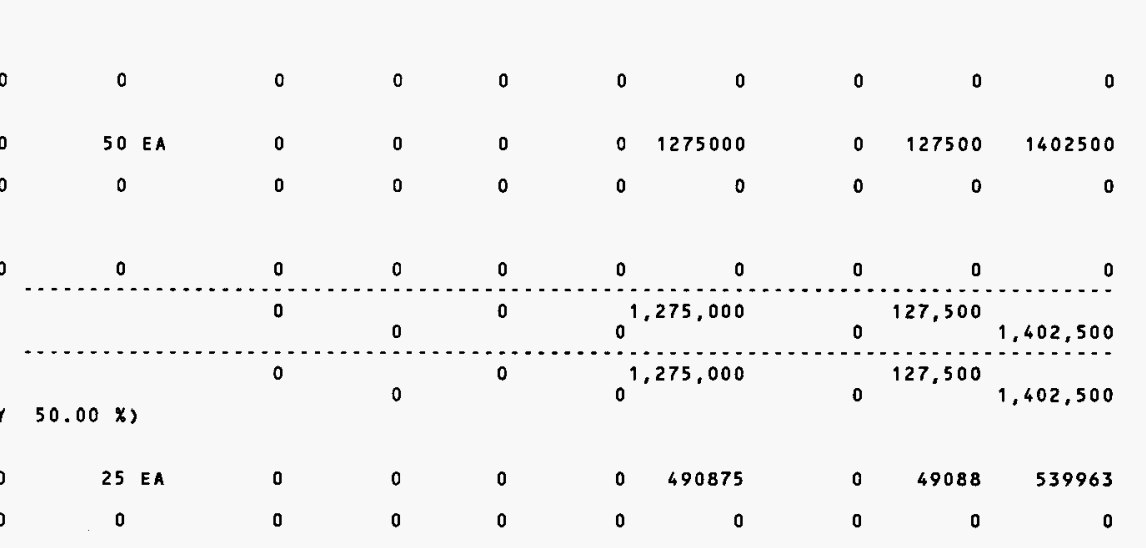

TOTAL WBS 325033 JUMPERS

0

0
0

0

$1,765,875$

176,588

$1,942,463$ 


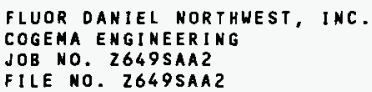

\section{ACCOUNT}

NUMBER

\section{DESCR IPI ION}

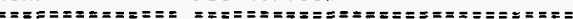

340000

PROJECT MANAGEMENT

340000.19 PROJECT MANAGEMENT

PROJECT MANAGEMENT

BASED ON 15\% OF CONSTRUCIION

SUBTOTAL PROJECT MANAGEMENT

TOTAL

COST CODE 00019

HBS 340000

(ESCALATION

O. DOK - CONT INGENCY
* IEST - INTERACTIVE ESTIMATING * *

HTI TASK 7 PROCESS IMPACTS STUDY

CAPITAL COST ESTIMATE, REV ?

PHMCROB - ESTIMATE DETAIL BY HBS, COST CODE

CODE QUANTITY MANHOURS LABOR USAGE

USAGE MATERIAL

SUB $=\geq \equiv== \pm=$ $\cos (\cos )$

PAGE 52

DATE 02/12/99 15:37:47

BY R.OHRT

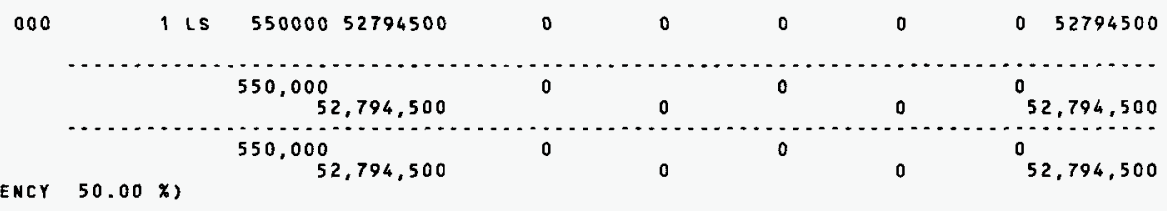

TOTAL WBS 340000 PROJECT MANAGEMENT

550,000

$52,794,500$
0

0
0

0
0 
FLUOR DANIEL NORTHWEST, INC.

COGEMA ENGINEERING

JOB NO. 2649SAA2

FILE NO. Z649SAA2

ACCOUNT

NUMBER

DESCR I PTION

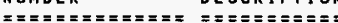

* * IEST - IHTERACT IVE ESTIMATING * *

HTI TASK 7 PROCESS IMPACTS SIUDY

CAPITAL COST ESTIMATE, REV 2
PHMCROB - ESTIMATE DETAIL BY WBS / COST CODE

\section{$\cos T$}

CODE

QUANTITY MANHOURS LABOR

\section{EQUIP}

USAGE MATERIAL CONTRACT

$======$

PAGE 53

DATE $02 / 12 / 99 \quad 15: 37: 47$

BY R.OHRT
$4,122,339$

$256,839,390$
126,974 $120,260,070$
$52,009,435$$$
70^{2}
$$ 
HNF-4098, Rev. 0

APPENDIX C

OPERATING COST ESTIMATE

FOR

AX TANK FARM THROUGH PROPOSED NEW TREATMENT FACILITY

C-1 
FLUOR DAHIEL NORTHWEST, INC.

COGEMA ENGINEER ING

JOB NO. Z649SABZ

FILE NO. 2649SAB2
* * IEST - INTERACTIVE ESTIMATING * *

HTI TASK 7 PROCESS IMPACTS STUDY

DPERATING COST ESTIMATE, REV 2

PHMCRO1 - PROJECT COST SUMMARY
PAGE 1 OF 8

DATE 02/12/99 15:52:25

BY R.OHRT

\begin{tabular}{|c|c|c|c|c|c|}
\hline $\begin{array}{l}\text { SQRT } \\
==\approx===\end{array}$ & 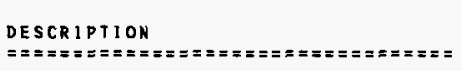 & $\begin{array}{l}\text { ESCALATED } \\
\text { TOTAL COST } \\
===========\end{array}$ & $=====$ & $\begin{array}{l}\text { IGENCY } \\
\text { TOTAL } \\
====\equiv=====\end{array}$ & $\begin{array}{c}\text { TOTAL } \\
\text { OOLLARS } \\
==\approx=\approx x==\equiv==\end{array}$ \\
\hline LMHC & LOCKHEED MARTIN HANFORD CORP. & $9,160,000$ & 65 & $5,930,000$ & $15,090,000$ \\
\hline WMH & WASTE MANAGEMENT HANFORD & $4,880,000$ & 35 & $1,710,000$ & $6,590,000$ \\
\hline
\end{tabular}

SUBTOTAL

SITE

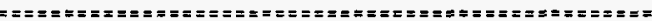

\begin{tabular}{|c|c|c|c|}
\hline $14,040,000$ & 54 & $7,640,000$ & $21,680,000$ \\
\hline 320,000 & 35 & 110,000 & 430,000 \\
\hline
\end{tabular}

$14,360,000$

54

$7,750,000$

$22,110,000$

PROJECT TOTAL

$14,360,000,100$

$22,110,000$

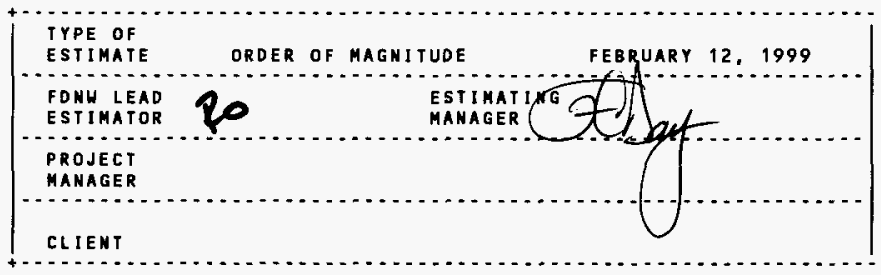

REMARKS :

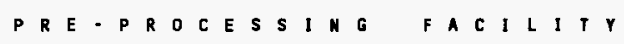

OPERATING COS TS

(ROUNDED/ADJUSTED TO THE NEAREST" $10,000 / 100,000 "$ - PERCENTAges Not Recalculated to Reflect Rounding) 
FLUOR DANIEL NORTHWEST, INC COGEMA ENGINEER ING

JOB HO. $26495 \mathrm{SAB} 2$

FILE NO. 2649 SAB 2

HBS DESCRIPTION

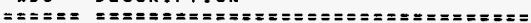

340001 COLD START-UP - 130 DAYS

340002 STANDBY PERIOD - 20 DAYS

340003 PROCESS ANC. EQUIP DEBRIS - 10 DAY

340004 MAINTENANCE PERIO0 - 20 DAYS

340005 STANDBY PERIOD - 245 DAYS

340006 PROCESSING TAHK DEBRIS - 60 DAYS

340007 DECONIDEMOB PROC EQUIP - 120 DAYS

341000 CONSUMABLES

342000 DISPOSAL COSTS

SUBTOTAL 34 LMHC OPERATING COSTS

PROJECT TOTAL
* * IEST - INTERACIIVE ESTIMAIING * *

HTI IASK 7 PROCESS IMPACTS STUDY

OPERATING COST ESTIMATE, REV 2

PHMCRO2 - WORK BREAKDOWN STRUCTURE (WBS) SUMMARY
PAGE 2 OF 8

DATE $02 / 12 / 99 \quad 15: 52: 28$

BY R. OHRT

\begin{tabular}{|c|c|c|c|c|c|c|c|c|}
\hline $\begin{array}{l}\text { ESTIMATE } \\
\text { SUBTOTAL } \\
== \pm===\end{array}$ & $===\underset{X}{E S C I}$ & $\begin{array}{l}\text { ALATION } \\
\text { TOTAL } \\
======\end{array}$ & 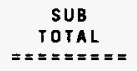 & 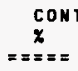 & $\begin{array}{l}\text { HGENCY } \\
\text { TOTAL } \\
=======\end{array}$ & $\begin{array}{c}\text { SUB } \\
\text { IOTAL } \\
========\end{array}$ & $\begin{array}{c}\text { SITE } \\
\text { ALLOCAT'N } \\
========\end{array}$ & $\begin{array}{c}\text { TOTAL } \\
\text { DOLLARS } \\
========\end{array}$ \\
\hline $\begin{array}{r}2087887 \\
77246 \\
274947 \\
277006 \\
946261 \\
2335709 \\
1662035 \\
1348423 \\
5030517\end{array}$ & $\begin{array}{l}0.00 \\
0.00 \\
0.00 \\
0.00 \\
0.00 \\
0.00 \\
0.00 \\
0.00 \\
0.00\end{array}$ & $\begin{array}{l}0 \\
0 \\
0 \\
0 \\
0 \\
0 \\
0 \\
0 \\
0\end{array}$ & $\begin{array}{r}2087887 \\
77246 \\
274947 \\
277006 \\
946261 \\
2335709 \\
1662035 \\
1348423 \\
5030517\end{array}$ & $\begin{array}{r}35 \\
35 \\
100 \\
35 \\
35 \\
100 \\
100 \\
35 \\
34\end{array}$ & $\begin{array}{r}730760 \\
27036 \\
274919 \\
96952 \\
331191 \\
2335475 \\
1661868 \\
471948 \\
1708002\end{array}$ & $\begin{array}{r}2818647 \\
104282 \\
549866 \\
373958 \\
1277452 \\
4671184 \\
3323903 \\
1820371 \\
6738519\end{array}$ & $\begin{array}{r}0 \\
0 \\
0 \\
0 \\
0 \\
0 \\
425602 \\
0\end{array}$ & $\begin{array}{r}2818647 \\
104282 \\
549866 \\
373958 \\
1277452 \\
4671184 \\
3323903 \\
2245973 \\
6738519\end{array}$ \\
\hline 14040031 & 0.00 & 0 & 14040031 & 54 & 7638154 & 21678185 & 425602 & 22103788 \\
\hline $\begin{array}{l}==== \\
40,031\end{array}$ & 0.00 & $\begin{array}{c}== \\
0\end{array}$ & $4,040,031$ & $==$ & $7,638,154$ & 678,185 & 425,602 & 88 \\
\hline
\end{tabular}


FLUOR DANIEL NORTHEEST, INC. COGEMA ENGINEERIN

JOB NO. 2649 SAB2

FILE NO. Z649SAB2
** IEST - INTERACTIVE ESTIMATING **

HTI TASK 7 PROCESS IMPACTS STUDY OPERATING COST ESTIMATE, REV 2 PHMCRO3 - ESTIMATE BASIS SHEET
PAGE 3 DF 8

DATE $02 / 12 / 99 \quad 10: 06: 08$

1. Estimate PURPOSE

ORDER OF MAGNITUDE ESTIMATE: THIS ESTIMATE HILL TO BE USED FOR BUDGETING PURPOSES ONLY.

2. ESTIMATE TECHAICAL BASIS

A. THIS ESTIMATE HAS BEEN PREPARED FOR HTI TASK 7 PROCESS IMPACTS STUDY AS REQUESTED BY COGEMA ENGINEERING.

B. THIS ESTIMATE HAS BEEN BASED ON A CUSTOMER PROVIDED SCHEDULE LISTING CREW AND DURATION FOR EACH ACTIVITY.

3. ESTIMATE METHODOLOGY

A. DIRECT COSTS:

DIRECT COSTS ARE SHOWH FOR THE LISTED CREHS BASED ON THE OPERATION SCHEDULE PROVIDED BY THE CUSTOMER.

THE LABOR RATES FOR LOCKHEEO MARTIN HANFORD CORP. AND WASTE MANAGEMENT HANFORD HAVE BEEN PROVIDED BY FDNH PROJECT

MANAGEMENT FOR INCLUSION IHTO THIS ESTIMATE.

B. DIRECT COST FACTORS:

(1) SALES TAX HAS BEEN APPLIED TO ALL MATERIALS AND EQUIPMENT PURCHASES AT 8X.

(2) PHMC SUBCONIRACTOR STANDARD LABOR RATES ARE THOSE LISTED IN IHE FINANCIAL DATA SYSIEM (FDS) FOST 321R REPORT ORGAHIZATION RATES PLUS ADDERS.

C. SITE ALLOCATIONS FACTORS:

SITE ALLOCATION FACTORS ARE DEVELOPED AHD PROVIDED BY FLUOR DANIEL HANFORD (FDH) FOR ESTIMATIMG USE.

the above factors are applied to estimated COSTS as SHOHh in the PhMCROG REPORT.

(1) FDH G\&A HASTE DISPOSAL a $15.7 \%$.

4. ESCALATION

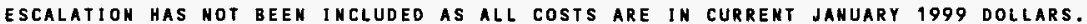

5. CONT INGENCY

A. DEFINITION OF CONTINGENCY AS PROVIDED BY DOE

"CONTIMGENCY COVERS COSTS THAT MAY RESULT FROM INCOMPLETE DESIGN, UNFORESEEM AHD UNPREDICTABLE CONDITIONS, OR UNCERTAINTIES WITHIN THE DEFINED PROJECT SCOPE. THE AMOUNT OF CONTINGEMCY WILL DEPEND ON THE STATUS OF DESIGN,

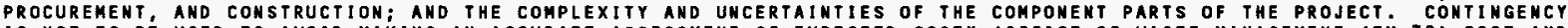

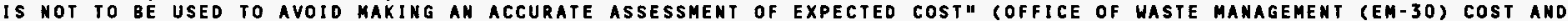
SCHEDULE GUIDE

B. CONTINGENCY ALLOHAHCE GUIDELINES

the doe guideline contingency allonance for a planing estimate under experimental conditions is up to iodox. 
FLUOR DANIEL NORTHUEST, INC.

COGEHA ENGINEERING

JOB NO. Z649SAB2

FILE NO. Z649SAB?

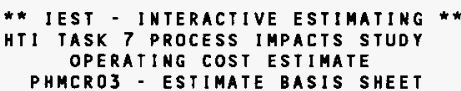

PAGE 4 OF 8

DATE $02 / 12 / 99 \quad 10: 06: 08$

BY R.OHRT

\section{METHODOLOGY}

CONTIMGENCY IS EVALUATED AT THE LOWEST HORK BREAKDOWN STRUCTURE (HBS) LEVEL WITHIN IHE COST ESTIMATE DETAILS. IT IS SUMMARIZED AT UPPER WBS LEVELS AND REPORTED ON THE SUMMARY REPORTS.

D. ANALYSIS

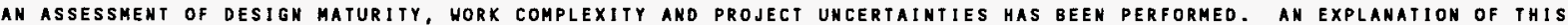
ASSESSMENT AND CONTINGENCY RATES WHICH HAVE BEEN ADDED TO THE COST OF WORK ARE AS FOLLOWS:

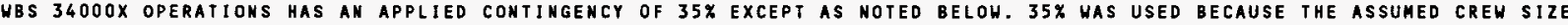
MAY PROVE TO BE TOO OPTIMISTIC AND ACTUAL CONDITIONS MAY WARRANT ADDITIONAL PERSOHNEL.

A $100 \%$ CONTIHGENCY WAS APPLIED TO THE PROCESSIHG AND DECONTAMINATION ACTIVITIES BECAUSE THESE PORTIONS HAVE THE POSSIBILITY OF DOUBLIMG SHOULD DEBRIS NEED TO BE REPROCESSED SECOND OR MAYBE THIRD TIME TO ACHIEVE ACCEPTABLE LEVELS. DECONIAMINAIION/DEMOB, SIMILARLY, COULD EXPERIENCE COST GROHTH EXCEEDING ESTIMATED AMOUNTS BECAUSE AT THIS TIME IT IS NOT KNOWN WHAT RADIATION LEVELS HILL BE EXPERIENCED OR WHAT THE EQUIPMENT CONFIGURATIONS HILL BE THAT HOULD REQUIRE DECONTAMINATION.

6. ROUNDING

THE PROJECT COST SUMMARY REPORT IS SUMMARIZED AND ADJUSTED/ROUNDED AS FOLLOHS :

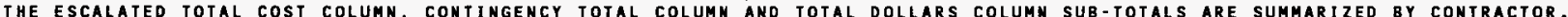
THE COLUMN SUBTOTALS ARE ADJUSTED/ROUNDED TO THE NEAREST $\$ 1,000 / \$ 10,000$. THE PROJECT TOTAL SUMMARY LINE TOTALS ARE AD JUSTED/ROUNDED TO THE MEAREST $\$ 10,000 / \$ 100,000$.

7. REMARKS

MAJOR ASSUMPTIONS WHICH HAVE BEEN MADE IN THE PREPARATION OF THIS ESTIMATE ARE AS FOLLONS:

A.) IT HAS BEM ASSUMED THAT ALL EQUIPMENT CAN BE DECONTAMIMATED AND/OR REUSED, NO DISPOSAL COSTS HAVE BEEN INCLUDED FOR CONTAMINATED EQUIPMENT.

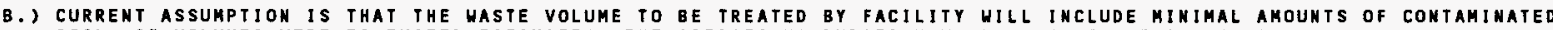
SOIL. IF VOLUMES WERE TO EXCEED ESTIMATES, THE OPERATIONS DURATION WOULD HEED TO BE INCREASED.

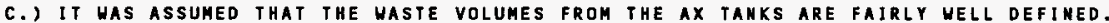

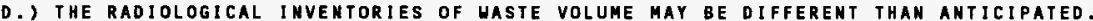

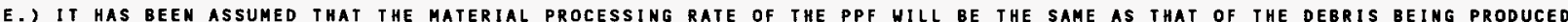
AT TANK FARMS. THUS NO INTERIM STORAGE FACILITY OR EXCESS IHVENTORY OF SHIELDED BOXES HERE IMCLUDED IN THE ESTIMATE.

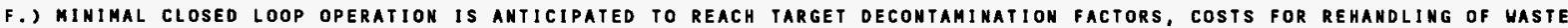
STREAM ARE TO BE ADDRESSED AS CONTINGENCY FACTOR 
HNF-4098 Rev, 0

FLUOR DANIEL NORTHHESI, INC.

COGEMA ENGINEERING

JOB NO. $26495 A B Z$

FILE NO. 2649 SAB2

HBS

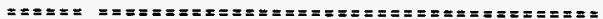

340001 COLD START-UP - 130 DAYS

340002 STANDBY PERIOO - 20 DAYS

340003 PROCESS ANC. EQUIP DEBRIS - 10 DAYS

340004 RAINTENANCE PERIOD - 20 DAYS

340005 STANDBY PERIOD - 245 DAYS

340006 PROCESSIMG TANK DEBRIS - 60 DAYS

340007 DECON/DEMOB PROC EQUIP - 120 DAYS

341000 CONSUMABLES

342000 DISPOSAL COSTS

SUBTOTAL 34

LHHC OPERATING COSTS

PROJECT TOTAL
* * IEST - INTERACTIVE ESTIMATING * *

HTI TASK 7 PROCESS IMPACTS STUDY

OPERATING COST ESTIMATE, REV 2

PHMCROS - CONSTRUCTION MANAGEMENT/OTHER COST SUMMARY

$\begin{array}{lcl}\text { ESTIMATE } & \text { CONSTRUCTION MANAGEMENT } & \text { OIHER } \\ \text { SUBTOTAL } & \mathbb{X} & \text { COSTS }\end{array}$

SUBTOTAL

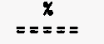

TOTAL

2087887

77246

274947

277006

946261

2335709

1662035

1662035

1348423
5030517

0.00

0.00

0.00

0.00

0.00

0.00

0.00

0.00

0.00

0.00

14040031
COSTS

$==== \pm==$

0
0
0
0
0
0
0
0
0
0

PAGE 6 OF 8

DATE O2/12/99 15:52:32

BY R.OHR
SUB

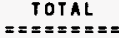

77246

274947

277006

046261

2335709

1662035

1662035

1348423

5030517

14040031 
FLUOR DANIEL NORTHHEST, INC.

COGEMA ENGINEERING

JOB NO. Z649SAB2

* * IEST - INTERACTIVE ESTIMATING * *

HT I TASK 7 PROCESS IMPACIS STUOY

OPERATING COST ESTIMATE, REV 2 PHMCROG - SITE ALLOCATIONS BY WBS

FILE NO. 2649 SAB2
PAGE 7 OF 8

DATE 02/12/99 15:52:14

BY R.OHRT
WBS DESCRIPIION

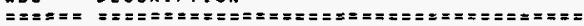

340001 COLO START-UP - 130 DAYS

340002 STANDBY PERIOD - 20 DAYS

340003 PROCESS ANC EQUIP DEBRIS - 10 DAYS

340004 MAINTENANCE PERIOD - 20 DAYS

340005 STANDBY PERIOD - 245 DAYS

340006 PROCESSING TANK DEBRIS. 60 DAYS

340007 DECONIDEMOB PROC EQUIP - 120 DAYS

349000 CONSUMABLES

342000 DISPOSAL COSTS

SUBTOTAL 34

LHHC OPERATING COSTS

PROJECT TOTAL
ESTIMATE

SUBTOTAL

$=== \pm== \pm=$

DYN

EQ. USAGE

FDH GFS/G\&A

2087887

77246

274947

277006

946261

2335709

1662035

1348423

5030517

14040031

$=\Sigma==\mathbf{=}$

$=======$

FDH MPR

.P. / S. C.

$F$

$\angle A B O R$

DH MPR/G\&A

MATERIAL

SITE ALLOC

$14,040,031$

0
0
0
0
0
0
0
0
0
0

0
0
0
0
0
0
0
0
0
0

$\begin{array}{rr}0 & 0 \\ 0 & 0 \\ 0 & 0 \\ 0 & 0 \\ 0 & 0 \\ 0 & 0 \\ 0 & 0 \\ 315261 & 315261 \\ 0 & 0 \\ 315261 & 315261\end{array}$


FLUOR DANIEL NORTHUEST, INC.

COGEMA ENGIMEERING

JOB NO. Z6495ABZ

FILE NO. Z649SAB2

WBS OESCRIPTIOH

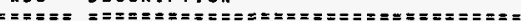

340001 COLD START-UP - 130 DAYS

340002 STANDBY PERIOD - 20 DAYS

340003 PROCESS ANC. EQUIP DEBRIS - 10 DAYS

340004 MAINTENANCE PERIOD - 20 DAYS

340005 STANDBY PERIOD - 245 DAYS

340006 PROCESSING TAKK DEBRIS - 60 DAYS

340007 DECON/DEKOB PROC EQUIP - 120 DAYS

341000 CONSUMABLES

342000 DISPOSAL COSTS

SUBTOTAL 34 LMHC OPERATING COSTS

PROJECT TOTAL
\# * IEST - INTERACT IVE ESTIMATING **

HTI TASK 7 PROCESS IMPACTS STUDY

DPERATING COST ESTIMATE, REV 2

PHMCRO7 - SITE ALLOCATION ESCALATION/CONTINGEHCY REPORT
PAGE 8 OF 8

$15: 52: 34$

BY R. OHR T

\begin{tabular}{|c|c|c|c|c|c|c|}
\hline $\begin{array}{l}\text { SITE ALLOC } \\
\text { SUBTOTAL } \\
=========\end{array}$ & $== \pm=$ & $\begin{array}{l}\text { LLATION } \\
\text { IOIAL } \\
======\pi=\end{array}$ & $\begin{array}{c}\text { SUB } \\
\text { TOIAL } \\
========\end{array}$ & $==\stackrel{\operatorname{con} T}{\underset{x}{*}==}$ & $\begin{array}{l}\text { I WGENCY } \\
\text { TOIAL } \\
=======\end{array}$ & $\begin{array}{c}\text { TOTAL } \\
\text { OOLLARS } \\
========\end{array}$ \\
\hline $\begin{array}{r}0 \\
0 \\
0 \\
0 \\
0 \\
0 \\
0 \\
315261 \\
0 \\
0\end{array}$ & $\begin{array}{l}0.00 \\
0.00 \\
0.00 \\
0.00 \\
0.00 \\
0.00 \\
0.00 \\
0.00 \\
0.00\end{array}$ & $\begin{array}{l}0 \\
0 \\
0 \\
0 \\
0 \\
0 \\
0 \\
0 \\
0\end{array}$ & $\begin{array}{r}0 \\
0 \\
0 \\
0 \\
0 \\
0 \\
0 \\
315261 \\
0 \\
0\end{array}$ & $\begin{array}{r}0 \\
0 \\
0 \\
0 \\
0 \\
0 \\
0 \\
35 \\
0\end{array}$ & $\begin{array}{r}0 \\
0 \\
0 \\
0 \\
0 \\
0 \\
0 \\
0 \\
110341 \\
0\end{array}$ & $\begin{array}{r}0 \\
0 \\
0 \\
0 \\
0 \\
0 \\
0 \\
425602 \\
0\end{array}$ \\
\hline 315261 & 0.00 & 0 & 315261 & 35 & 110341 & 425602 \\
\hline
\end{tabular}


FLUOR DAHIEL NORTHUEST, INC.

COGEMA ENGINEERING

JOB NO. Z649SABZ

FILE NO. Z649SAB2
* * IEST - INTERACTIVE ESTIMATING * *

HTI TASK 7 PROCESS IMPACIS STUDY

OPERATING COST ESTIMATE, REV?

PHMCRO8 - ESTIMATE DETAIL BY WBS / COST CODE
PAGE

OATE $02 / 12 / 99 \quad 15: 52: 36$

BY
EQUIP

NUMBER DESCRIPTION

COLD START - UP - 130 DAYS

340001

340001.06

ENVIRONMENTAL WORK

$340001.0610000 * * * \pi * * * * * \hbar * * * * * * * * * * * * * * * * * * 700$

NORMAL OPERATION - DAY
$* * * * * * * * * * * * * * * * * * * * * * * * * * *$

340001.0610001

HOURS BELOW ARE FOR 1 DAY SHIFT FOR 130 DAYS

340001.06100101 TRAFFIC MASTER FOR INCOMING TRUCKS

340001.06100122 RPT'S FOR

IHCOMING TRUCKS

340001.0610014 2 DECON OPERATORS FOR
340001.0610016 INCOMING TRUCKS
34 PLANT OPERATORS

340001.06100142 DECON OPERATORS
340001.0610016 INCOMING TRUCKS

340001.06100168 PLANT OPERATORS
340001.06100183 COHTROL ROOM OPERATORS

340001.06100221 TRAFFIC MASTER FOR

OUT GOING TRUCKS

340001.06100242 RPT'S FOR

QUT GOING TRUCKS

340001.06100262 DECON OPERATORS FOR

340001.0610030 OUT GOING IRUCKS

340001.0610032 1 CONTROL ROOM SUPERVISOR

340001.0610034 1 PACKAGING SUPERVISOR

340001.06100362 ELECTRICAL/INSTR CRAFTSMEN

340001.06100381 MECHANICAL CRAFTSMAN

340001.0610040 I FITTER CRAFTSMAN

340001.06100421 CRAFT SUPERVISOR

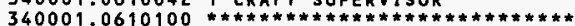

NORMAL OPERATION - GRAVEYARD

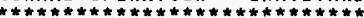

340001.06101021 CRAFT SUPERVISOR

340001.06101041 EXPEDITER

340001.06101061 MILLWRIGHT

340001.06101081 FITTER

340001.06101102 ELECTRICAL/INSTRUMENTATION

$340001.0610200 * * * * * * * * * * * * * * * * * * * * * * * * * * * *$
700

0

0

700

130 DAY

130 DAY

2080

130 DAY

2080

130 DAY

130 DAY

130 DAY

130 DAY

130 DAY

130 DAY

130 DAY

130 DAY

130 DAY

130 DAY

130 DAY

0

8320

3120

1040

2080

2080

1040

1040

1040

2080

1040

1040

1040

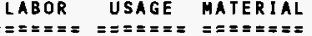

$== \pm= \pm== \pm$

700

700

700
700

700
700

700

700

130 DAY

130 DAY

130 OAY

130 DAY

0

1040

1040

1040

49691
99382

0
0
0
0
0
0
0
0
0
0
0
0
0
0
0
0
0

0
0
0
0
0
0

99382

49691
99382
99382
397530
149074
49691
99382
99382
64813
64813
64813
99382
49691
49691
49691
0

49691
0991
99382
0

MORMAL OPERATION - OFFICE SUB- EQUIP- OH\&P
CNTRACT MENT

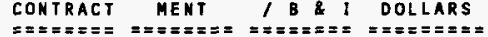

0

0

0

$\left(\frac{100}{2}\right.$


FLUOR DANIEL NORTHHEST, INC.

COGEMA ENGINEERING

JOB NO. Z649SAB2

FILE NO. Z649SAB2

\section{ACCOUNT}

NUMBER

DESCRIPTION

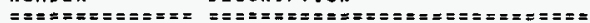

340001.06102021 MAHAGER

340001.06102041 SECRETARY

340001.06102061 JANITOR

340001.06102081 EXPEDITER

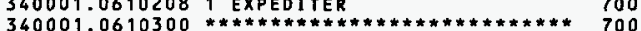

NORMAL OPER. - HVAC MAINT.

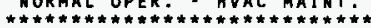

340001.06103012 POWER OPERATORS PER SHIFT 700 FOR A TOTAL OF 2 I SHIFTS PER HEEK.

SUBTOTAL ENVIRONMENTAL WORK

TOTAL

COST CODE 70006

UBS 340001 (ESCALATION

$0.00 \%$ - CONTINGENCY

$35.00 x$
** IEST - INTERACTIVE ESTIMATING * *

HTI TASK 7 PROCESS IMPACTS STUDY

OPERATING COST ESTIMATE, REV 2

PHMCROB - ESTIMATE DETAIL BY NBS $/$ COST CODE
PAGE 2

DATE $02 / 12 / 99 \quad 15: 52: 36$

BY R. OHRT

COST EQUIP SUB - EOUIP. OH\&P TOTAL

CODE QUANTITY MANHOURS LABOR USAGE MATERIAL CONTRACT MENT I B I DOLLARS

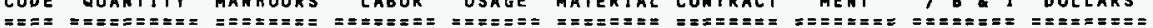

\begin{tabular}{|c|c|c|c|c|c|c|c|c|c|c|}
\hline $\begin{array}{l}700 \\
700 \\
700 \\
700 \\
700\end{array}$ & $\begin{array}{r}130 \\
130 \\
130 \\
130 \\
0\end{array}$ & $\begin{array}{l}\text { DAY } \\
\text { DAY } \\
\text { DAY } \\
\text { DAY }\end{array}$ & $\begin{array}{r}1040 \\
1040 \\
1040 \\
1040 \\
0\end{array}$ & $\begin{array}{r}64813 \\
29817 \\
49691 \\
49691 \\
0\end{array}$ & $\begin{array}{l}0 \\
0 \\
0 \\
0 \\
0\end{array}$ & $\begin{array}{l}0 \\
0 \\
0 \\
0 \\
0\end{array}$ & $\begin{array}{l}0 \\
0 \\
0 \\
0 \\
0\end{array}$ & $\begin{array}{l}0 \\
0 \\
0 \\
0 \\
0\end{array}$ & $\begin{array}{l}0 \\
0 \\
0 \\
0 \\
0\end{array}$ & $\begin{array}{r}64813 \\
29817 \\
49691 \\
49691 \\
0\end{array}$ \\
\hline \multirow[t]{4}{*}{700} & 130 & DAY & 4368 & 208703 & 0 & 0 & 0 & 0 & 0 & 208703 \\
\hline & & & 4,928 & & 0 & & 0 & $\because$ & 0 & $\ldots$ \\
\hline & & & & 87,887 & & 0 & & o & & $.087,887$ \\
\hline & & & 4.928 & 87887 & 0 & 0 & 0 & 0 & 0 & 087887 \\
\hline
\end{tabular}

44,928

$2,087,887$
0

0

(20)

0 $2,087,887$ 
FLUOR DANIEL NORTHUEST, INC.

COGEMA ENGINEERING

JOB NO. Z649SAB2

* IEST - IHTERACTIVE ESTIMATING * *

HII TASK 7 PROCESS IMPACTS STUDY

OPERATING COSI ESTIMATE, REV 2

FILE NO. Z649SAB2

PHMCROB - ESTIMATE DETAIL BY UBS / COST CODE

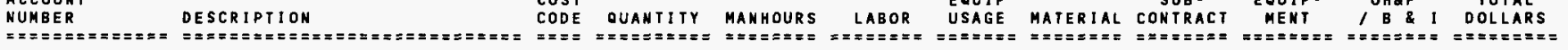

PAGE 3

DATE $02 / 12 / 99 \quad 15: 52: 36$

BY R.OHRT

COST EQUIP SUB- EOUIP- OH\&P TOTAL

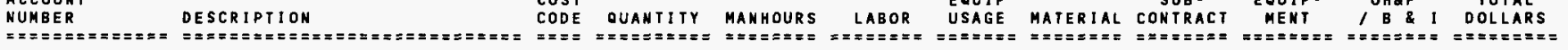

340002

STANDBY PERIOD - 20 DAYS

340002.06 ENVIRONMENTAL WORK

$340002.0610300 * * * * * * * * * * \hbar * * * * * * * * * * * * * * * * * 700$ STANDBY PHASE - HVAC MAINT.

340002.06103012 POWER OPERATORS PER SHIFT 700 FOR A TOTAL OF 21 SHIFTS PER

$340002.0630000 * * * * * * * * * * * * * * * * * * * * * * * * * * * * 700$ STANDBY PHASE - DAY SHIFT

340002.06300021 RPT FOR GENERAL SUPPORT

1 DECON OPERATOR FOR GEHERAL 700 SUPPORT

340002.06300061 CONTROL RMIEQUIPMENT OPER. 340002.0630008 I MANAGER

340002.06300101 SECRETAR

340002.06300121 JANITOR

\section{SUBTOTAL ENVIRONMENTAL WORK}

TOTAL COST CODE 70006

UBS 340002

CESCALA

$0.00 \%-$ CONTINGENCY

700
700
700
700

20 DAY

0

$672 \quad 32108$

0

20 DA

20 DAY

20 DAY

20 DAY

0

0

0

0

(0)

0

0

o

0

32108

$1,632 \quad 77,246$

0

1,6320

77.246

$35.00 \times)$

$\begin{array}{llllllll}160 & 7645 & 0 & 0 & 0 & 0 & 0 & 7645\end{array}$

$\begin{array}{llllllll}160 & 7645 & 0 & 0 & 0 & 0 & 0 & 7645\end{array}$

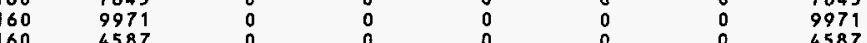

$\begin{array}{llllllll}160 & 4587 & 0 & 0 & 0 & 0 & 0 & 4587\end{array}$

00000076

0

0 77,246

0

0

0

77.246

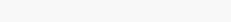

TOTAL WBS 340002 STANDBY PERIOD - 20 DAYS

1,632

77.246

0

0

0

0

77,246 
FLUOR DANIEL NORTHWEST, INC.

CDGEMA ENGINEERING

JOB NO. 2649 SAB2

* IEst - Interactive estimating *

HTI TASK 7 PROCESS IMPACTS STUDY

PHMCROS - ESTIMATE DETAIL BY WBS/ COST CODE
OPERATING COST ESTIMATE, REV ?

PAGE

BY

$02 / 12 / 99 \quad 15: 52: 36$

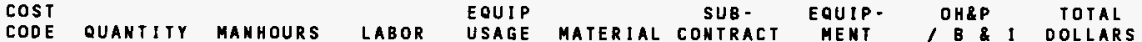

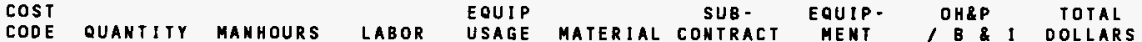

DESCRIPTION

CODE QUANTITY MANHOURS LABOR USAGE MATERIAL CONTRACT

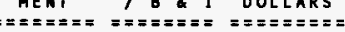

PROCESS ANC. EQUIP DEBRIS - 10 DAYS

340003

ENVIRONMENTAL WORK

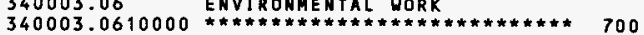

PROCESS ANCILLARY EQUIPMENT

DEBRIS - OAY AND SHING SHIFT

340003.0610001

HOURS BELON ARE FOR 2 SHIFTS DAY AND SHING FOR 10 DAYS

340003.06100101 TRAFFIC MASTER FOR I HCONING TRUCKS

340003.06100122 RPT IS FOR

I MCOMING TRUCKS

340003.06100142 DECON OPERATORS FOR

I MCONING TRUCKS

340003.06100168 PLANT OPERATORS

340003.06100183 CONTROL ROOM OPERATORS

340003.06100221 TRAFF1C MASTER FOR

OUT GOING TRUCKS

340003.06100242 RPT'S FOR

OUT GOING TRUCKS

340003.06100262 DECON OPERATORS FOR

OUT GOING TRUCKS

340003.06100301 SHIFT SUPERVISOR

340003.06100321 CONTROL ROOM SUPERVISOR

340003.06100341 PACKAGING SUPERVISOR

340003.06100362 ELECTRICAL/INSTR CRAFTSMEN

340003.06100381 MECHANICAL CRAFTSMAN

340003.06100401 FITTER CRAFTSMAM

340003.06100421 CRAFT SUPERVISOR

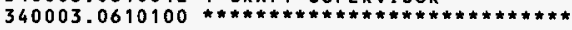

MAINTENANCE DURING ANCILLARY

EQUIP. PROCESS - GRAVEYARD

340003.06101021 CRAFT SUPERVISOR

340003.06101041 EXPEDITER

340003.06101061 MILLUR IGHT

340003.0610108

1 FITTER

340003.0610110

ELECTR

700

0

10 DAY

10 DAY

320

10 DAY

320

15290

10 DAY

1280

10 DAY

61158
22934

7645

10 DAY $320 \quad 15290$

10 DAY

15290

10 DAY $\quad 160 \quad 9971$

10 DAY $160 \quad 9971$

10 DAY $\quad 160 \quad 9971$

10 DAY $\quad 320 \quad 15290$

10 DAY $\quad 160 \quad 7645$

10 DAY $160 \quad 7645$

10 DAY

0

7645

700

160
0

0

10 DAY

10 DAY

10 DAY

10 DAY

10 DAY

0

$\begin{array}{rr}80 & 0 \\ 80 & 0 \\ 80 & 3822 \\ 80 & 3822 \\ 160 & 7645 \\ 0 & 0\end{array}$

OFFICE DURING ANCILLARY

$\begin{array}{rl}0 & 0 \\ 0 & 0 \\ 822 & 0 \\ 822 & 0 \\ 645 & 0 \\ 0 & 0\end{array}$

0

0

7645

15290

15290

61158

22934

7645

15290

15290

9971

9971
9971

15290

15290
7645

7645

7645
0

0
0
822
3822
645
0


FLUOR DANIEL NORTHUEST, INC.

COGEMA ENGINEERING

JOB NO. Z649SAB2

FILE NO. Z649SAB2

\section{ACCOUNT}

NUMBER

DESCRIPTION

\section{EQUIPMENT PROCESSING}

340003.0610202 I MANAGER

340003.06102041 SECRETARY

340003.0610206 I JANITOR

340003.06102081 EXPEDITER

$340003.0610300 * * * * * * * * * * * * * * * * * * * * * * * * * * * * *$

HVAC MAINT. OURING ANCILLARY EQUIPMENT DEBRIS PROCESSIHG

340003.06103012 POHER OPERATORS PER SHIFT FOR A TOTAL OF 21 SHIFTS PER WEEK.

SUBTOTAL EHVIRONMENTAL WORK

TOTAL

COST CODE 70006

NBS 340003

CESCALATION

$0.00 \%=$ CONTINGENCY
* * IEST - INTERACTIVE ESTIMATING * *

HTI TASK 7 PROCESS IMPACTS STUDY

DPERATING COST ESTIMATE, REV 2

PAGE

DATE $02 / 12 / 99 \quad 15: 52: 36$

BY R. OKRT
COST EQUIP SUB - EQUIP- OH\&P TOTAL

CODE QUAHTITY MANHOURS LABOR USAGE MATERIAL CONTRACT MENT / B I DOLLARS

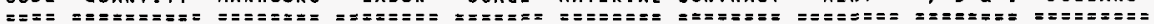

$\begin{array}{llll}10 & & & \\ 10 & \text { DAY } & 80 & 4986 \\ 10 \text { DAY } & 80 & 2294 \\ 10 \text { DAY } & 80 & 3822 \\ 0 & & 80 & 3822\end{array}$

700

10 DAY

336

16054

0

0

0

0

0

16054
0

274,947

0

0

274,947

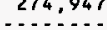

274,947

TOTAL WBS 340003 PROCESS ANC. EQUIP DEBRIS - 10 DAYS

5,776

274,947
0
0
0

274,947 
FLUOR DANIEL NORTHWEST, INC.

COGEMA ENGIMEER ING

JOB NO. 2649 SAB2

FILE NO. 2649 SAB2

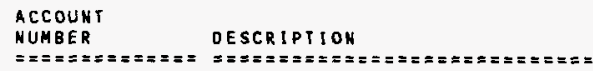

* IEST - INTERACTIVE ESTIMATIMG * *

HTI TASK 7 PROCESS IMPACTS STUDY

OPERATING COST ESTIMATE, REV 2

PHMCROB - ESTIMATE DETAIL BY WBS/ COST CODE

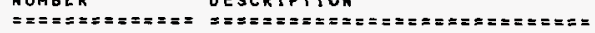

USAGE
PAGE 6

DATE $02 / 12 / 99 \quad 15: 52: 36$

BY R.OHRT

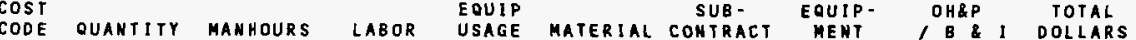

340004 MAINTENANCE PERIOD - 20 DAYS

340004.06

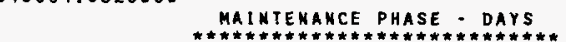

340004.06200104 RPT'S FOR GENERAL 700

MAINTEMANCE SUPPORT

340004.06200124 DECON OPERATORS FOR

GENERAL MAINTEMAMCE SUPPORT

340004.06200144 CONTROL ROOM AND EQUIPMENT DPERATORS

$340004.0620016 \%$ SHIFT SUPERVISOR

340004.06200189 CONTROL ROOM SUPERVISOR

340004.06200201 PACKAGING SUPERVISOR

340004.06200224 ELECT/INSTRU. CRAFTSMEN

340004.06200242 MECH/MILLWRIGHT CRAFISMEN

340004.06200262 FITTER CRAFTSMEN

340004.06200282 CRAFT SUPERVISORS

$340004.0620100 * * * * * * * * * * * * * * * * * * * * * * * * * * * *$

MAIHTENANCE PHASE - OFFICE

340004.06201021 MAHAGER

340004.06201041 SECRETARY

340004.06201061 JANITOR

340004.06201082 EXPEDITERS

700
700

MAINT. PHASE - HVAC MAINT:

340004.06203022 POHER OPERATORS PER SHIFT 700 FOR A TOTAL OF 21 SHIFTS PER WEEK.

SUBTOTAL ENVIRONMENTAL WORK

TOTAL

\section{COST CODE 70006
NBS 340004}

CESCALATION

$0.00 \%$ - CONTINGENCY $35.00 x$ )

$0 \quad 0 \quad 0$

o

o

20 Dar

640

30579

20 DAY

640

30579

20 DAY

30579

20 DAY

20 DAY

20 DAY

20 DAY

20 DAY

20 DAY

CONTRACT

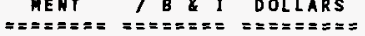

0

$$
640
$$

9971

160

160

640
320
320

15290

15290

700

320

15290

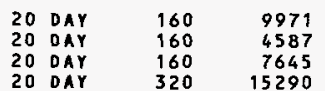

20 DAY

0

15290

20 DAY

$672 \quad 32108$

0

0

32108

o

30579

30579

30579

9979

9971

39885

15290

15290

15290
0

- . . . . . . . . . . . .

0

0

0

277,006

5,472

0

0

0

0

277.006

TOTAL WBS 340004 MALNTENANCE PER:OD - 20 DAYS

5,472

277,006

0

(n)

o

0

o

0

277,006 
FLUOR DANIEL NORTHUEST, INC. COGEMA ENGINEERING

FILE NO. 2649SAB2

\section{ACCOUNT}

NUMBER

DESCRIPT IOH

* IEST - INTERACTIVE ESTIHATING **

HTI TASK 7 PROCESS IMPACTS STUDY

OPERATING COST ESTIMATE, REV 2

PHMCRO8 - ESTIMATE DETAIL BY HBS/ COST CODE JOB NO. 2649 SAB2

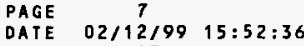 \\ BY R.OHRT}

EOUIP. OHEP TOTAL COST
COOE OUANTITY MANHOURS LABOR USAGE MATERIAL CONTRACT EQUIP- OOHEP

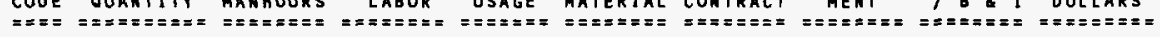

340005

STANDBY PERIOD - 245 DAYS

340005.06 ENVIRONMENTAL WORK

$340005.0610300 * * * * * * * * * * * * * * * * * * * * * * * * * * * * 700$ STANDBY PHASE - HVAC MAIMT.

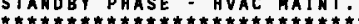

340005.06103012 POWER DPERATORS PER SHIFT FOR A TOTAL OF 21 SHIFTS PER WEEK.

340005.0630000 年 STANDBY PHASE - DAY SHIFT

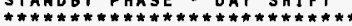

340005.06300021 RPT FOR GENERAL SUPPORT

700 SUPPORT

340005.06300061 COHTROL RM/EQUIPMENT OPER 340005.0630008 T MANAGER

340005.06300101 SECRETARY

340005.06300121 JANITOR

\section{SUBTOTAL ENVIRONMENTAL WORK}

TOTAL

COST CODE 70006

HBS 340005 (ESCALATION

$0.00 \%$ - CONTINGENCY
0

0

245 DAY $8232 \quad 393325$

0

0

o

o

0

0

0

0

0

0

0

o

0

0

0

0

700
700

$\begin{array}{ll}1960 & 93649\end{array}$

$\begin{array}{llllll}0 & 0 & 0 & 0 & 0 & 93649 \\ 0 & 0 & 0 & 0 & 0 & 93649\end{array}$

700

700
700

700

245 DAY

1960

93649

245 DAY $\quad 1960 \quad 93649$

245 DAY $1960 \quad 122147$

245 DAY

$1960 \quad 56193$

$1960 \quad 93649$

245 DAY

19,992

946,261

19,992

946,26

$35.00 \%)$

649

$\begin{array}{llllll}0 & 0 & 0 & 0 & 0 & 93649\end{array}$

$\begin{array}{rrrrrr}0 & 0 & 0 & 0 & 0 & 93649 \\ 0 & 0 & 0 & 0 & 0 & 122947\end{array}$

$\begin{array}{llllll}0 & 0 & 0 & 0 & 0 & 56193 \\ 0 & 0 & 0 & 0 & 0 & 93640\end{array}$

0

o

946,261

0

0

o

0

$\mathbf{0}$

946,261
393325

TOTAL UBS 340005 STANOBY PERIOD - 245 DAYS

19,992

946,261 o

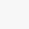

0
0

946,261 
FLUOR DANIEL NORTHEEST, INC. COGEMA ENGINEERING

JOB NO. Z649SABZ

* IEST - INTERACTIVE ESTIMATING * *

HTI TASK 7 PROCESS IMPACTS STUDY

OPERATING COST ESTIMATE, REV 2

PHMCROB - ESTIMATE OETAIL BY UBS/ COST CODE
PAGE

DATE
BY
02/12/99 $15: 52: 36$
R.OHRT
COST EQUIP

CODE QUANTITY MANHOURS LABOR USAGE

NUMBER DESCRIPIION

SUB -

CONTRACT

EQUIP-

OH\&P

TOTAL

PROCESSING TANK OEBRIS - 60 DAYS

ENVIROHMENTAL NORK

$340006.0610000 * * * * * \hbar * * * * * * * * * * * * * * * * * * * * * * 700$ PROCESS TAHK DEBRIS

340006.0610001

HOURS BELOW ARE FOR 3 SHIFTS PER DAY FOR 60 DAYS.

340006.06100101 TRAFFIC MASTER FOR INCOMING TRUCKS

340006.06100122 RPT'S FOR

INCOMING TRUCKS

340006.06100142 DECON OPERATORS FOR

INCOHING TRUCKS

340006.06100168 PLANT OPERATORS

340006.06100183 CONTROL ROOM OPERATORS

340006.06100221 TRAFFIC MASTER FOR OUT GOING TRUCKS

340006.06100242 RPT'S FOR

OUT GOING TRUCKS

340006.06100262 DECON OPERATORS FOR OUT GOING TRUCKS

340006.06100301 SHIFT SUPERVISOR

340006.06100321 CONTROL ROOM SUPERVISOR

340006.06100341 PACKAGING SUPERVISOR

340006.06100362 ELECTRICAL/INSTR CRAFTSHEN

340006.06100381 MECHANICAL CRAFTSMAN

340006.06100401 FITTER CRAFTSMAM

340006.06100421 CRAFT SUPERYISOR

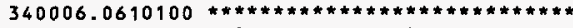

MAINTEKANCE DURING ANCILLARY

EQUIP. PROCESS - GRAVEYARD

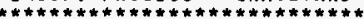

340006.06101021 CRAFT SUPERYISOR

340006.0610104 1 EXPEOITER

340006.06101061 MILLURIGHT

340006.06101081 FITTER

340006.06101102 ELECTRICAL/INSTRUMENTATION

$340006.0610200 * * * * * * * * * * * * * * * * * * * * * * * * * * * *$

OFFICE DURING AHCILLARY

700
700
700
700
700
700
700
700
700
700
700
700
700
700
700
700


700
700
700
700
700
700

68803

$2880 \quad 137606$

137606

60 DAY

2880

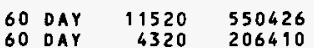

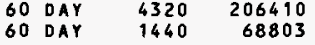

60 DAY $2880 \quad 137606$

60 DAY

2880

137606

60 DAY

60 DAY

60 DAY

60 DAY

60 DAY

60 DAY

0

$1440 \quad 89741$

$1440 \quad 89741$

$1440 \quad 89741$

$2880 \quad 137606$

$1440 \quad 68803$

$1440 \quad 68803$

60 DAY

60 DAY

60 DAY

60 DAY

60
1440

$1440 \quad 68803$ 
FLUOR DANIEL NORTHHEST, IHC. COGEMA ENGINEERING

JOB NO. 2649SAB2

* * IEST - INTERACTIVE ESTIMATING * *

HT 1 TASK 7 PROCESS IMPACTS STUOY

OPERATING COST ESTIMATE, REV ?

PHMCRO8 - ESTIMATE DETAIL BY HBS / COST CODE

FILE NO. 2649\$AB2
PAGE 9

DATE $02 / 12 / 99 \quad 15: 52: 36$

BY

. OHR T

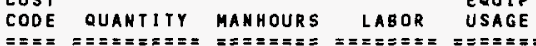

DESCRIPTION

SUB -

EQUIP -

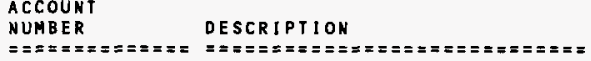

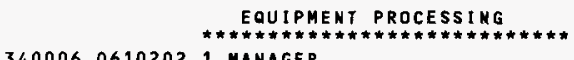

021 MANAGER

340006.06 .102041 SECRETAR

340006.0610206 I JANITOR

340006.06102081 EXPEDITER

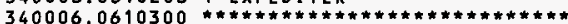

HVAC MAINT. DURING ANCILLARY

EQUIPMENT DEBRIS PROCESSIHG

340006.06103012 POWER OPERATORS PER SHIFT FOR A TOTAL OF 21 SHIFTS PER

WEEK.

SUBTOTAL ENVIRONMENTAL WORK

TOTAL

COST CODE 70006

WBS 340006

(ESCALATION

0.00X * CONTINGENCY

\begin{tabular}{|c|c|c|c|c|}
\hline $\begin{array}{l}700 \\
700 \\
700 \\
700 \\
700\end{array}$ & $\begin{array}{l}60 \\
60 \\
60 \\
60 \\
0\end{array}$ & $\begin{array}{l}\text { DAY } \\
\text { DAY } \\
\text { DAY } \\
\text { DAY }\end{array}$ & $\begin{array}{l}480 \\
480 \\
480 \\
480\end{array}$ & $\begin{array}{r}29914 \\
13762 \\
22934 \\
22934\end{array}$ \\
\hline
\end{tabular}

60 DAY

2016

96324

MATERIAL CONTRACT

OHEP TOTAL

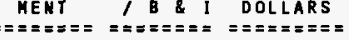

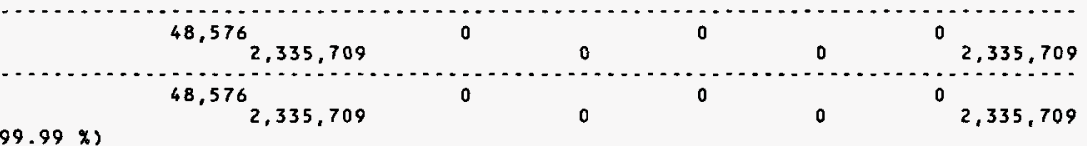

TOTAL WBS 340006 PROCESSING TANK DEBRIS - 60 DAYS

48,576

$2,335,709$

0

$2,335,709$ 
FLUOR DANIEL NORTHWEST, INC.

COGEMA ENGINEER ING

JOB NO. 2649SAB2

FILE NO. 2649SAB2
* * IEST - INTERACTIVE ESTIMATING * *

HTI TASK 7 PROCESS IMPACTS STUDY

PHMCRO8 - ESTIMATE DETAIL BY WBS / COST CODE
OPERATING COST ESTIMATE, REV 2

PAGE 10

DATE 02/12/99 15:52:36

BY

QUANTITY MANHOURS LABOR UQUIP USAGE MATERIAL CONTRACT EQUIP. OHEP I TOIAL

OUANTIY MANHOURS SUB- EQUIP. OH\&P D TOIAL . OHRT

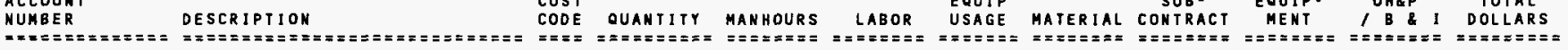

340007

DECON/DEMOB PROC EQUIP - 920 DAYS

340007.06 ENVIROMMEKTAL NORK

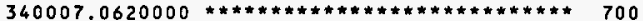
MAINTENANCE - DAY SHIFT 340007.06200104 RPT'S FOR GEHERAL

MAINTENANCE SUPPORT

$\begin{array}{ll}340007.0620012 & \text { MAINTENANCE SUPPORT } \\ & \text { GENON OPERATORS FOR } \\ & \end{array}$ 4 CONTROL ROOM AND EQUIPMENT 700

340007.06200161 SHIFT SUPERVISOR

340007.06200181 CONTROL ROOM SUPERVISOR

340007.06200201 PACKAGING SUPERVISOR

340007.06200224 ELECT/1WSTRU. CRAFTSMEN

340007.06200242 MECH/MILLHRIGHT CRAFTSMEN

340007.06200262 FITTER CRAFTSMEH

340007.06200282 CRAFT SUPERVISORS

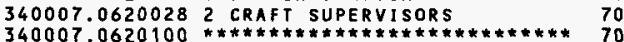

MAINTENANCE PHASE - OFFICE

340007.06201021 MANAGER

340007.06201041 SECRETARY

340007.06201061 JANITOR

340007.06201082 EXPEDITERS

$340007.0620300 * * * * * * * * * * * * * * * * * * * * * * * * * * * * 700$

MAINT. PHASE - MVAC MAINT.

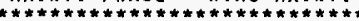

340007.06203022 POUER OPERATORS PER SHIFT FOR A TOTAL OF 21 SHIFTS PER WEEK.

\section{SUBTOTAL ENVIRONMENTAL WORK}

TOTAL COST CODE 70006

HBS 340007

(ESCALATION

$0.00 \%$ - CONTINGENCY
120 DAY

120 DAY

120 DAY

120 DAY

120 DAY

120 DAY

120 DAY

120 DAY

120 DAY

120 DAY

0

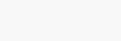

120 DAY

$\begin{array}{llrl}120 & \text { DAY } & 960 & 59827 \\ 120 & \text { DAY } & 960 & 27523 \\ 120 & \text { DAY } & 960 & 45869 \\ 120 & \text { DAY } & 1920 & 91738\end{array}$

0

0

$\begin{array}{rr}0 & 0 \\ 3840 & 183475 \\ 3840 & 183475 \\ 3840 & 183475 \\ 960 & 59827 \\ 960 & 59827 \\ 960 & 59827 \\ 3840 & 239309 \\ 1920 & 91738 \\ 1920 & 91738 \\ 1920 & 91738 \\ 0 & 0 \\ & \\ 960 & 59827 \\ 960 & 27523 \\ 960 & 45869 \\ 1920 & 91738 \\ 0 & 0 \\ & \end{array}$

120 DAY

$4032 \quad 192649$

0

0

0
0

0
0
0

0

0
0
0

700

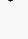

0
0
0
0
0
0
0
0
0
0
0
0

0
0
0
0
0

0
0

0

183475

183475

183475

59827

59827

59827
239309

239309

91738

91738

91738
0

59827

27523

45869

91738
0

192649

$1,662.035$

0

$1,662,035$

0

o

1.662,035 
FLUOR DANIEL NORTHHEST, INC.

COGEMA ENGINEERING

JOB NO. 2649 SAB2

FILE NO. $26495 \mathrm{SAB} 2$

ACCOUNT

HUMBER

DESCRIPTION

PHMCROS - ESTIMATE DETAIL BY WBS I COST CODE

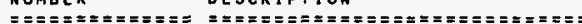

\section{CONSUMABLES}

341000.06

ENVIRONMENTAL WORK

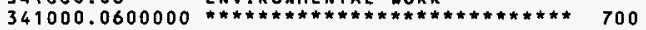

CONSUMABLES
$* * * * * * * * * * * * * * * * * * * * * * * * * * * *$

341000.0600002 NITRIC ACID, 57\% SOLUTION

341000.0600004 CAUSTIC, $50 \dot{X}$ SOLUTION

341000.0600006 PORTLAND́ CEMENT

SUBTOTAL ENVIRONMENTAL WORK
SALES TAX $8.00 \%$

TOTAL COST CODE 70006

WBS 341000

(ESCALATION

$0.00 \%$ - CONTINGENCY

TOTAL HBS 341000 CONSUMABLES
0

0
* IEST - INTERACTIVE ESTIMATING *

HTI TASK 7 PROCESS IMPACTS STUOY

OPERATING COST ESTIMATE, REV 2

$\cos T$

CODE QUANTITY MANHOURS LABOR USAGE $=======================$

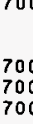

700
700
700

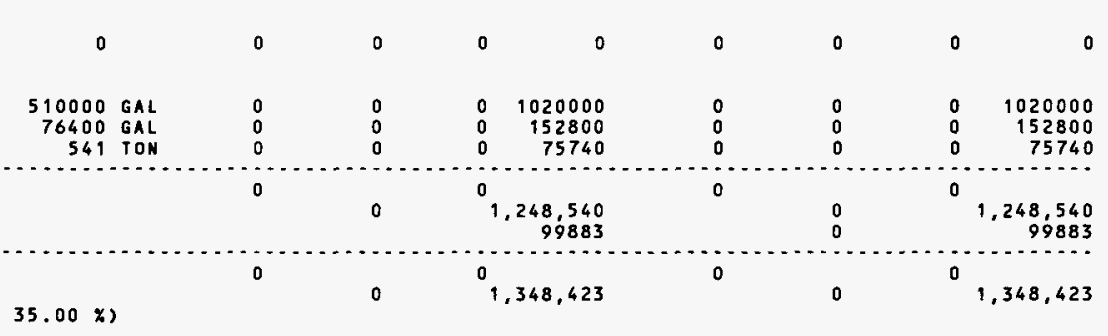

0

0

SUB -

PAGE

DATE 02/12/99 15:52:36

BY

R. OHRT

EQUTP- OH\&P TOTAL MENT $\quad 6 \&$ I DOLLARS

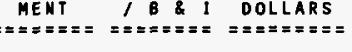

1

348,42
0 
FLUOR DANIEL NORTHWEST, INC.

COGEMA ENGINEERIHG

JOB NO. Z649SAB2

* * IEST - INTERACTIVE ESTIMATING * *

HTI IASK 7 PROCESS IMPACTS STUDY

OPERATING COST ESTIMATE, REV 2

FILE NO. $26495 \mathrm{SAB} 2$

$\begin{array}{ll}\text { ACCOUNT } & \text { OESCRIPIION } \\ \text { NUMBER } & \text { OESCIPION }\end{array}$

EQUIP
PAG

DAT

BY

12

$02 / 12 / 99 \quad 15: 52: 36$

R.OHRT

CODE QUANTITY MANHOURS SUB -

EQUIP- DHEP TOIAL

EQRE

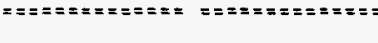

362000 DISPOSAL COSTS

342000.06 ENVIROHHENTAL WORK

$342000.0600000 * * 0^{2}$ DISPOSAL COSTS

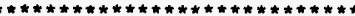

342000.0600002 CATEGORY 1 LLH TO ERDF 700 AT \$6O/TON.

PHMC GRA AT 15.7\% AND GFS 700

342000.0600004 AT PHOTION.
ATM $5.2 \%$ AT $15.7 \%$ AND
$21.7 \%$ OR \$13.02/TON.

342000.0600004 AT \$6O/TON.
PHMC GRA AT $15.7 \%$ AND
AT $5.2 \%$ F OR TOTAL O
$21.7 X$ OR \$13.02/TON.

342000.0600010 CATEGORY 3 LLW TO LLBG 700

AT $\$ 51.83 / C F$.

342000.0600012 PHMC G\&A AT 15.7\% AND GFS 700 AT $5.2 \%$ FOR A TOTAL OF

$21.7 X$ OR $\$ 11.25 / C F$.

342000.0600100 342000.0600102 3 TEAMSTERS

3 LABORERS

3 FLATBEDS WASTE WATER TREATMENT AT 200 ETF, ASSUME 1.2 MILLION GAL. PRODUCT OF STREAM 151

EVAPORATOR CONDENSATE.

342000.0600201 ACCORDIHG TO MARK BOWMAN AT WMH, THERE WOULD BE NO
INTERNAL CHARGE FOR THE PROCESSING.

SUBTOIAL ENVIRONHENTAL HORK SALES TAX $8.00 \%$

TOTAL COST CODE 70006 HBS 342000 $0.00 X$ - CONTINGENCY

\begin{tabular}{|c|c|c|c|c|c|c|c|c|c|}
\hline 0 & - & 0 & 0 & 0 & 0 & 0 & 0 & 0 & 0 \\
\hline 6360 & TaN & 0 & 0 & 0 & 0 & 381600 & 0 & 0 & 381600 \\
\hline 6360 & TON & 0 & 0 & 0 & 0 & 82807 & 0 & 0 & 82807 \\
\hline 70000 & CF & 0 & 0 & 0 & 0 & 3628100 & 0 & 0 & 3628100 \\
\hline 0000 & $C F$ & 0 & 0 & 0 & 0 & 787500 & 0 & 0 & 787500 \\
\hline $\begin{array}{r}60 \\
60 \\
60 \\
* *\end{array}$ & $\begin{array}{l}\text { DAY } \\
\text { DAY } \\
\text { DAY } \\
\text { GAL }\end{array}$ & $\begin{array}{r}1512 \\
1512 \\
0 \\
0\end{array}$ & $\begin{array}{r}72243 \\
72243 \\
0 \\
0\end{array}$ & $\begin{array}{r}0 \\
0 \\
4080 \\
0\end{array}$ & $\begin{array}{r}0 \\
0 \\
1800 \\
0\end{array}$ & $\begin{array}{l}0 \\
0 \\
0 \\
0\end{array}$ & $\begin{array}{l}0 \\
0 \\
0 \\
0\end{array}$ & $\begin{array}{l}0 \\
0 \\
0 \\
0\end{array}$ & $\begin{array}{r}72243 \\
72243 \\
5880 \\
0\end{array}$ \\
\hline
\end{tabular}

0

0

0

0

0

0

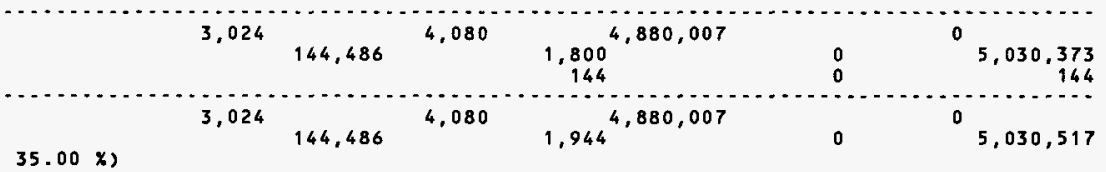

TOTAL NBS 342000 DISPOSAL COSTS

3,024

4,080

$4,880,007$

$5,030,517$ 
FLUOR DANIEL NORTHWEST, INC.

COGEMA ENGINEERING

JOB NO. Z649SAB?

* * IEST - INTERACTIVE ESTIMATING * *

HTI TASK 7 PROCESS IMPACTS STUDY

OPERATING COST ESTIMATE, REV 2

PHMCROS - ESTIMATE DETAIL BY WBS / COST CODE

COST EQUIP

CODE OUANTITY MANHDURS LABOR USAGE

DESCRIPTION

\section{ACCOUNT}

NUMBER

USAGE
$=====$

\section{SUB -}
PAGE 13
DATE $02 / 12 / 99 \quad 15: 52: 36$
BY R.OHRT

\section{EQUIP- OH\&P TOTAL}

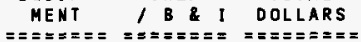

REPORT TOTAL

162,232

$7,805,577$

$4,0801,350,367^{4,880,007}$

o

0

$14,040,031$ 


\section{DISTRIBUTION SHEET}

\begin{tabular}{|c|c|c|c|c|c|}
\hline \multirow{2}{*}{$\begin{array}{l}\text { To } \\
\text { DISTRIBUTION }\end{array}$} & \multirow{2}{*}{\multicolumn{3}{|c|}{$\begin{array}{l}\text { From } \\
\text { D. L. Becker }\end{array}$}} & \multicolumn{2}{|c|}{ Page 1 of 1} \\
\hline & & & & \multicolumn{2}{|c|}{ Date $3-17-99$} \\
\hline \multirow{2}{*}{\multicolumn{4}{|c|}{$\begin{array}{l}\text { Project Title/Work Order } \\
\text { AX Tank Farm Process Impacts Study, HNF-4098, Rev. } 0\end{array}$}} & \multirow{2}{*}{\multicolumn{2}{|c|}{$\begin{array}{l}\text { EDT No. } 619524 \\
\text { ECN No. }\end{array}$}} \\
\hline & & & & & \\
\hline Name & MSIN & $\begin{array}{l}\text { Text } \\
\text { With All } \\
\text { Attach. }\end{array}$ & Text Only & $\begin{array}{l}\text { Attach./ } \\
\text { Appendix } \\
\text { Only }\end{array}$ & $\begin{array}{l}\text { EDT/ECN } \\
\text { Only }\end{array}$ \\
\hline $\begin{array}{l}\text { CENTRAL FILES } \\
\text { PROJECT FILES - HTI } \\
\text { DOE READING ROOM }\end{array}$ & $\begin{array}{l}\text { B1-07 } \\
\text { R1-41 } \\
\mathrm{H} 2-53\end{array}$ & $\begin{array}{l}x \\
x \\
x\end{array}$ & & & \\
\hline $\begin{array}{l}\text { D.L. BECKER } \\
\text { T.M. BROUNS } \\
\text { H.L. BUDWEG } \\
\text { T.J. CONRADS } \\
\text { V.F. FITZPATRICK } \\
\text { E.A. FREDENBURG } \\
\text { J.S. GARFIELD } \\
\text { J.C. HENDERSON } \\
\text { D.L. NICHOLS } \\
\text { R.W. POWELL } \\
\text { D.C. RAMSOWER } \\
\text { W.R. ROOT } \\
\text { P.A. SCOTT } \\
\text { J.C. SONNICHSEN } \\
\text { W.J. STOKES } \\
\text { C.D. WEST }\end{array}$ & $\begin{array}{l}\mathrm{HO}-22 \\
\mathrm{~K} 9-69 \\
\mathrm{~A} 3-03 \\
\mathrm{R} 3-73 \\
\mathrm{R} 2-89 \\
\mathrm{R} 1-04 \\
\mathrm{R} 3-73 \\
\mathrm{~B} 2-05 \\
\mathrm{~B} 2-05 \\
\mathrm{R} 3-75 \\
\mathrm{H} 3-28 \\
\mathrm{R} 2-53 \\
\mathrm{~K} 9-46 \\
\mathrm{H} 6-26 \\
\mathrm{R} 3-75 \\
\mathrm{AO}-21\end{array}$ & $\begin{array}{l}X \\
X \\
X \\
X \\
X \\
X \\
X\end{array}$ & . & & $\begin{array}{l}X \\
X \\
X \\
X \\
X \\
X \\
X\end{array}$ \\
\hline
\end{tabular}

